
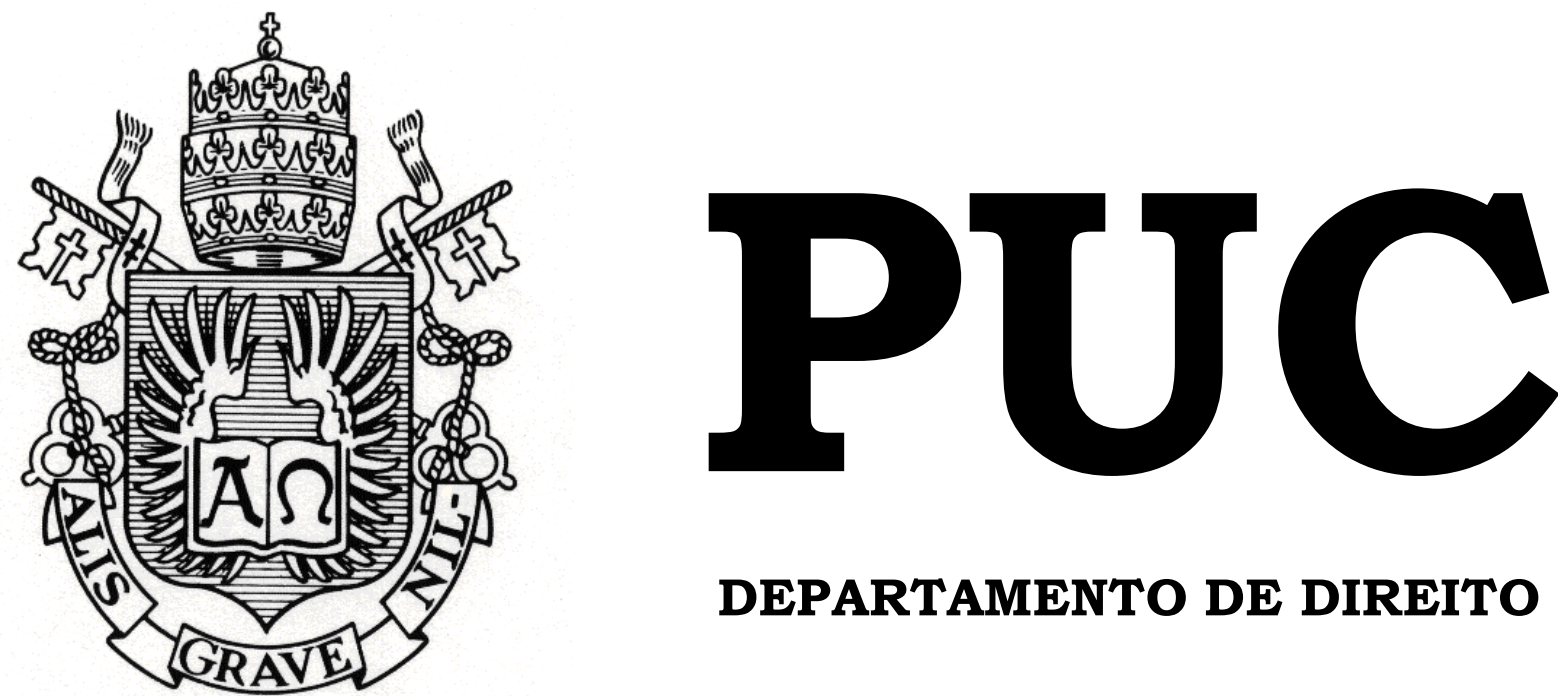

DEPARTAMENTO DE DIREITO

DESCONSTITUIÇÃO DA COISA SOBERANAMENTE JULGADA INCONSTITUCIONAL: decisões judiciais contra legem e a potencial superação das regras jurídicas

por

Pedro de Hollanda Dionisio

ORIENTADORA: Prof. Marianna Montebello Willeman 2012.2

PONTIFÍCIA UNIVERSIDADE CATÓLICA DO RIO DE JANEIRO RUA MARQUÊS DE SÃO VICENTE, 225 - CEP 22453-900 RIO DE JANEIRO - BRASIL 


\section{DESCONSTITUIÇÃO DA COISA SOBERANAMENTE JULGADA INCONSTITUCIONAL: decisões judiciais contra legem a a potencial superação das regras juridicas}

por

Pedro de Hollanda Dionisio

Monografia apresentada ao

Departamento de Direito da Pontificia Universidade Católica do Rio de Janeiro (PUC-Rio) para a obtenção do Título de Bacharel em Direito.

Orientadora: Marianna Montebello Willeman 
Aos meus pais, Fernando e Lúcia, e à Vó Lúcia, por serem sempre um incentivo aos meus estudos. 


\section{AGRADECIMENTOS}

Pelos ensinamentos passados ao longo de minha graduação, agradeço, primeiramente, aos professores da Faculdade de Direito da PUCRio com os quais tive a oportunidade de aprender.

Em especial, agradeço à Marianna Montebello Willeman, não só pela grande ajuda na elaboração desta monografia, da qual foi orientadora, mas também por ter despertado em mim, por meio de suas aulas, um especial interesse pelo Processo Constitucional.

Agradeço, ainda, aos amigos e integrantes do Escritório Andrade \& Fichtner, todos fundamentais para meu desenvolvimento acadêmico e profissional.

Por fim, sou muito grato à minha família, principal responsável por tudo o que sou hoje, à Camila, em razão de seu apoio e de sua paciência nessa difícil etapa de minha vida e aos amigos de infância e da Faculdade, pelos necessários momentos de descontração.

A todos, muito obrigado. 


\section{Resumo e Palavras-Chave}

O presente estudo pretende analisar a possibilidade de o Poder Judiciário, após esgotado o prazo para ajuizamento da ação rescisória, desconstituir uma decisão transitada em julgado que viole determinada norma constitucional. Para tanto, inicialmente, realiza uma abordagem crítica das principais teses que fundamentam os dois polos do debate. Em seguida, procura demonstrar que a rescisão da coisa soberanamente julgada depende, invariavelmente, de uma decisão que, no caso concreto, supere a regra jurídica disposta no artigo 495 do CPC. Adiante, no Capítulo seguinte, cuida da potencial superabilidade das regras jurídicas em geral e, em especial, da possibilidade de afastamento casuístico pelo julgador do limite temporal para a rescisão das decisões transitadas em julgado. Ao final, avalia em quais circunstâncias será viável ao Poder Judiciário superar uma regra jurídica válida, e cuja incidência é inequívoca, para desconstituir a coisa soberanamente julgada inconstitucional.

Direito Constitucional - Processo Constitucional - Coisa Julgada Inconstitucional - Superabilidade Normativa 
Introdução. 09

Capítulo I - Os entendimentos doutrinários acerca da coisa soberanamente julgada inconstitucional e da possibilidade de sua relativização 14

I.1. Conceituação e delineamento do problema....................................... 14

I.2. A doutrina tradicional e o suposto caráter absoluto da coisa soberanamente julgada e da segurança jurídica

I.3. Críticas ao entendimento tradicional - a inexistência de norma jurídica absoluta.

I.4. A doutrina moderna e a necessária relativização da coisa julgada inconstitucional. 27

I.5. Críticas aos exageros da doutrina relativista - a indispensável proteção à garantia fundamental à coisa julgada 31

\section{Capítulo II - A desconstituição da coisa soberanamente julgada} inconstitucional como hipótese de decisão contra legem ........................ 39

II.1. O conceito de decisão judicial contra legem ..................................... 39

II.2. A ação rescisória como o único meio processual apto a rescindir a coisa julgada. 44

II.3. A natureza jurídica da norma disposta no artigo 495 do CPC e seu núcleo de sentido 51

II.4. A indiscutível constitucionalidade em tese da norma derivada do artigo 495 do CPC 54

II.5. Conclusão parcial: a indispensabilidade de uma decisão contrária à lei para a desconstituição da coisa soberanamente julgada 
Capítulo III - O conflito em concreto entre regras jurídicas e a potencial superabilidade do limite temporal para a desconstituição da coisa julgada. 60

III.1. A importância da obediência à regra insculpida no artigo 495 do

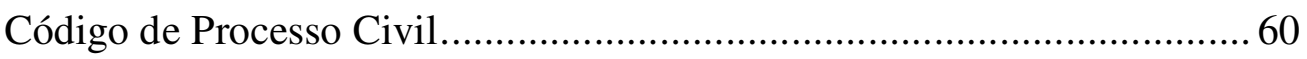

III.2. O Direito como um sistema de normas superáveis....................... 66

III.3. A potencial superabilidade da regra do artigo 495 do CPC ............ 71

Capítulo IV - A potencial superação da regra do artigo 495 do CPC em conflito com outras normas jurídicas - construção de parâmetros específicos para a rescisão da coisa soberanamente julgada .............. 76

IV.1. A ofensa pela decisão transitada em julgado há mais de dois anos a

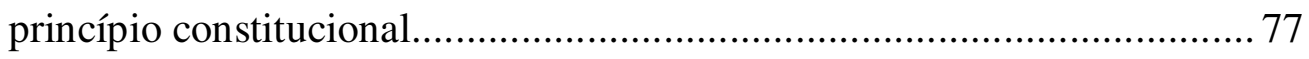

IV.2. A violação pela coisa soberanamente julgada à regra

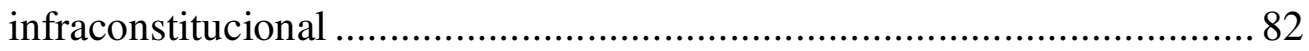

IV.3. A hipótese da coisa soberanamente julgada violadora de regra constitucional. 85

IV.4. A importância do respeito aos precedentes na universalização das hipóteses de rescisão da coisa soberanamente julgada.

Síntese conclusiva 92

Referências Bibliográficas 97 
AC $\quad-$ Ação Cautelar

ADCT - Ato das Disposições Constitucionais Transitórias

ADI - Ação Direta de Inconstitucionalidade

Ag. $\quad-$ Agravo

art. $\quad-$ Artigo

C. $\quad$ - Colendo

CE - Ceará

CF - Constituição Federal

CF/88 - Constituição Federal de 1988

CPC - Código de Processo Civil

Des. - Desembargador

DF $\quad-$ Distrito Federal

DNA - deoxyribonucleic acid

E. - Egrégio

EC - Emenda Constitucional

ed. $\quad-$ Edição

Exmo. - Excelentíssimo

fls. $\quad-$ Folhas

Ibid. - Ibidem

IF $\quad-$ Intervenção Federal

Min. $\quad-$ Ministro

$\mathrm{n}^{\mathrm{o}} \quad-$ número

p. $\quad-$ página

PI $\quad-$ Piauí

PUC-Rio - Pontifícia Universidade Católica do Rio de Janeiro

PR $\quad-$ Paraná

RE $\quad-$ Recurso Extraordinário

Rel. $\quad-$ Relator

REsp - Recurso Especial 


$\begin{array}{ll}\text { RJ } & - \text { Rio de Janeiro } \\ \text { RN } & - \text { Rio Grande do Norte } \\ \text { RS } & - \text { Rio Grande do Sul } \\ \text { SP } & - \text { São Paulo } \\ \text { STF } & - \text { Supremo Tribunal Federal } \\ \text { STJ } & - \text { Superior Tribunal de Justiça } \\ \text { TJ/SC } & - \text { Tribunal de Justiça de Santa Catarina } \\ \text { v. } & - \text { Volume } \\ \text { vol. } & - \text { Volume } \\ \S & - \text { Parágrafo }\end{array}$




\section{Introdução}

É de importância ímpar, assim como fonte de profundas controvérsias na doutrina processual e constitucional brasileira contemporânea, o estudo acerca da coisa soberanamente julgada inconstitucional e suas hipóteses de rescisão. São incontáveis os estudos já escritos sobre o tema, bem como os julgados já proferidos enfrentando o problema, sem que a doutrina ou a jurisprudência nacional tenham, em algum momento, chegado a um consenso.

Com efeito, a imutabilidade das decisões judiciais transitadas em julgado foi tradicionalmente tratada pela doutrina como um princípio absoluto dentro do ordenamento jurídico pátrio. Evitava-se, com tal argumento, qualquer discussão sobre a possibilidade de revisão da coisa julgada eivada do vício de inconstitucionalidade na hipótese de já passado o prazo decadencial para o ajuizamento da ação rescisória, ou caso fugisse a hipótese em questão daquelas previstas em lei para o manejo de tal medida.

Assim, o enorme prestígio depositado sobre o princípio constitucional da intangibilidade da coisa julgada, a ponto de the ser conferido o caráter de absoluto após findo o prazo previsto em lei para sua rescisão, era - e ainda é, por parte da doutrina contemporânea - justificada pela necessidade inerente a qualquer sistema jurídico de se evitar a eternização dos conflitos submetidos ao Poder Judiciário, o que seria alcançado por meio da máxima proteção à coisa soberanamente julgada ${ }^{1}$. Tendo essa sido formada, segundo tal doutrina, fechar-se-iam todas as portas para eventual revisão da decisão judicial que lhe serviu de base.

Recentemente, porém, ao ver-se diante de situações em que a coisa soberanamente julgada claramente violava normas de matriz constitucional ou encobria graves injustiças perpetradas pela sentença que lhe serve de base, parte da doutrina atentou para o fato de que nem a coisa julgada nem

\footnotetext{
${ }^{1}$ Como será visto de forma mais detalhada à frente, define-se, para os fins do presente trabalho, coisa soberanamente julgada como aquela em que o prazo decadencial previsto em lei para o ajuizamento da ação rescisória já se esgotou.
} 
o princípio da segurança jurídica, do qual se origina, podem ser considerados absolutos, sendo necessário, em certas hipóteses, sua desconstituição. Deu-se origem, assim, à chamada doutrina relativista.

Contudo, muito embora tal movimento revolucionário no Direito brasileiro parta da correta premissa de que nenhuma norma constitucional possa ser considerada absoluta, uma grande parcela de seus participantes incorre em exageros, tratando a desconstituição da coisa soberanamente julgada inconstitucional como regra, e não como exceção, o que lhe vem rendendo duras e bem fundadas críticas.

De fato, se é certo que o princípio constitucional da intangibilidade da coisa julgada, apesar de fundamental para o Estado Democrático de Direito, não é absoluto, também não o são as normas constitucionais que eventualmente entrarão com ele em conflito no caso concreto.

Desse modo, indaga-se - e esse é o objeto principal deste estudo como deverá decidir o juiz caso se depare com um pleito que, mesmo depois de passado o prazo para ajuizamento da ação rescisória, pretenda desconstituir uma sentença judicial transitada em julgado que viole determinado princípio ou regra de matriz constitucional.

Será que sempre deverá ser respeitado o prazo decadencial para o manejo da ação rescisória manejo? Como o magistrado deverá solucionar a tensão entre regras e princípios constitucionais e infraconstitucionais em conflito, a qual poderá ocorrer no caso do manejo da ação rescisória para se desconstituir a coisa soberanamente julgada inconstitucional? Por quais meios processuais será considerada legítima sua rescisão?

Para cuidar de tão instigante e controverso assunto, este estudo é dividido em cinco Capítulos, além da presente Introdução.

Logo no primeiro tópico do capítulo inaugural, será devidamente delineado o objeto da controvérsia que o presente estudo busca solucionar. Conforme se verá, parece que a grande questão que divide a doutrina brasileira não diz respeito simplesmente à possibilidade de desconstituição da sentença transitada em julgado que viola determinada norma da 
Constituição, mas sim de se rescindir a coisa soberanamente julgada inconstitucional.

A seguir, o Capítulo I demonstrará, de modo objetivo, os principais fundamentos utilizados pela doutrina tradicional - que, como já apontado, encontra adeptos na doutrina contemporânea e na jurisprudência atual para embasar o entendimento de que a coisa soberanamente julgada é impassível de desconstituição, devendo ser respeitada a qualquer custo.

Buscará trazer também as principais bases do chamado movimento relativista, sem a preocupação, porém, de abordar todas as teses sobre o tema. Críticas também não serão poupadas aos exageros dessa parte da doutrina, que, sob o pretexto de evitar a perpetuação de injustiças e inconstitucionalidades encobertas sob o manto da coisa julgada, acabam por esvaziar o sentido e a autoridade de tal garantia fundamental.

Adiante, no segundo Capítulo, far-se-á uma aprofundada análise do fenômeno da desconstituição da coisa soberanamente julgada, buscando identifica-lo, adiante, como uma hipótese especial de decisão judicial contra legem, entendida como aquela que, dentre outros aspectos, supera o uma determinada regra jurídica, criando exceções casuísticas a sua aplicação.

Para tanto, serão identificadas, uma a uma, as características essenciais das decisões contrárias à lei e, em seguida, demonstrado que o Poder Judiciário, para que rescinda uma decisão judicial transitada em julgado há mais de dois anos, não poderá se socorrer de outro meio, senão o proferimento de uma decisão dessa natureza, com todos os aspectos que lhe são peculiares.

De valor fundamental para o presente estudo, o Capítulo III, por sua vez, se dedicará a uma detida investigação da possibilidade, em nosso sistema jurídico, da casuística superação pelo intérprete da norma insculpida no artigo 495 do Código de Processo Civil.

Serão, ao longo do primeiro item deste Capítulo, expostas as principais razões pelas quais se considera especialmente importante a 
observância do comando desta regra pelo Judiciário. Ver-se-á, inclusive, que provavelmente são esses os motivos que contribuem de forma mais incisiva para que a possibilidade de rescisão da coisa julgada após ultimado o prazo bienal seja um tema tão polêmico em nossa doutrina e jurisprudência.

Desse modo, a potencial superação de tal regra - assim como do sistema legal, como um todo - será assunto para os dois últimos itens, os quais buscarão trazer a resposta para a instigante indagação que moveu, desde o início, os estudos que basearam o presente trabalho: faz-se possível, em nosso sistema jurídico atual, a rescisão da coisa julgada após o fim do prazo estabelecido para o ajuizamento da ação rescisória?

Por sua vez, o Capítulo IV será dedicado inteiramente ao estudo de hipóteses de conflito em concreto entre a regra disposta no artigo 495 do CPC e outras normas jurídicas.

Nesse momento, a partir da análise do conflito em concreto entre tal regra e outras normas jurídicas - sejam elas regras ou princípios, de hierarquia constitucional ou não - construir-se-ão alguns critérios objetivos que poderão ser observados pelo Judiciário quando diante de uma pretensão rescisória fundada na violação da decisão transitada em julgado há mais de dois anos a uma norma jurídica.

Por óbvio, não se terá a mínima pretensão de se esgotar o tema, já que, na prática, é inviável antecipar as infinitas hipóteses, bem como suas potenciais particularidades fáticas, que poderão ser observadas pelo julgador em caso de conflito em concreto entre a regra que institui um limite temporal para a rescisão da coisa julgada e outras normas que compõem o ordenamento.

Restará concluído, ao fim do Capítulo, que cumpre à jurisprudência, sobretudo ao Supremo Tribunal Federal, intérprete máximo da Constituição, fixar, ao longo do tempo, as hipóteses em que se poderá introduzir uma exceção não escrita à regra do artigo 495 do CPC. 
A consolidação de precedentes nesse sentido, bem como sua obediência pelos demais órgãos do Judiciário, conferirá às decisões que rescindem a coisa soberanamente julgada um caráter universal, o que, como será visto, é essencial para sua legitimação em nosso Estado Democrático de Direito.

Ao final, na conclusão, serão resumidas as ideias centrais que permearam o presente estudo. 


\section{CAPÍTULO I - Os entendimentos doutrinários acerca da coisa soberanamente julgada inconstitucional e da possibilidade de sua relativização}

No presente Capítulo buscar-se-á traçar um panorama geral tanto da doutrina tradicional, que rechaça qualquer possibilidade de se desconstituir a coisa soberanamente julgada, quanto da doutrina moderna, a qual busca, de diversas formas, relativizá-la frente à inconstitucionalidade ou, conforme o caso, às injustiças perpetradas por algumas decisões judiciais que dela se aproveitam.

Ademais, por se entender que as críticas a ambas as doutrinas são inevitáveis, não serão elas deixadas para um momento posterior. Estarão dispostas, como se verá, logo após a apresentação das principais bases que dão suporte às diversas correntes sobre o tema.

Mas antes disso, é preciso que se delimite o real problema a ser aqui tratado, assim como que se definam os conceitos fundamentais, necessários à devida compreensão do tema.

\section{I.1. Conceituação e delineamento do problema}

O fenômeno da res iudicata inconstitucional ocorre quando a sentença judicial que serve de base para a formação da coisa julgada viola alguma norma de matriz constitucional, seja ela explícita ou implícita na Constituição Federal.

Nesse sentido, conforme aponta Paulo Otero em obra pioneira sobre o tema ${ }^{2}$, a decisão judicial pode transgredir a Carta Constitucional, primeiramente, quando seu conteúdo viola direta e imediatamente uma determinada norma constitucional.

\footnotetext{
2 OTERO, Paulo. Ensaio sobre o caso julgado inconstitucional. Lisboa: Editora Lex, 1993, p. $65 / 69$.
} 
Nesse caso, em distinção que será útil quando da análise da interação entre o princípio da intangibilidade da coisa julgada inconstitucional e outras normas constitucionais, diferencia o autor as decisões que violam direitos e garantias fundamentais (a qual chama de "Hipótese A") daquelas que violam quaisquer outras normas constitucionais ("Hipótese B").

Em uma segunda e última hipótese de violação à Carta Magna, pode a sentença judicial aplicar, para solucionar o caso em questão, uma norma inconstitucional, tenha ela sido declarada previamente inconstitucional, em sede de controle concentrado, pelo Poder Judiciário ("Hipótese C"), ou não (“Hipótese D") $)^{3}$.

Explica Paulo Otero que a situação em que a decisão judicial recusa a aplicação de uma determinada norma constitucional por reputá-la contrária à Constituição não configura uma hipótese autônoma às anteriores. Nesse caso, indica o autor que a norma aplicada pelo juiz para fundamentar sua decisão (em substituição à norma indevidamente afastada) pode ser inconstitucional ("Hipótese E") ou conforme a Constituição (“Hipótese F").

A “Hipótese E", em verdade, prevê uma situação enquadrada pela "Hipótese C" ou " $D$ ", dependendo do caso, tendo em vista que, aqui, o juiz estará baseando sua sentença em uma norma inconstitucional. A "Hipótese $F^{\prime}$, por sua vez, como bem observa o jurista lusitano, trata-se de caso de ilegalidade da decisão, e não de inconstitucionalidade propriamente. Vejamos sua elucidante explicação sobre o tema:

\footnotetext{
"Se a norma que o tribunal vai aplicar é também ela não inconstitucional, tal como a norma que ela afastou, então esta situação não é substancialmente diferente das decisões judiciais ilegais decorrentes da aplicação da lei x, em vez da lei y. (...).

No entanto, quer o juiz recuse a aplicação da norma legalmente aplicável ao caso concreto, porque acha que o mesmo não se subsume à norma (= erro interpretativo de direito, quer entenda que mesma é inconveniente, inoportuna ou erradamente considera ser inconstitucional, desde que a decisão que ele profira não seja fundada em norma inconstitucional, entendemos que deve o caso julgado seguir um regime unitário. Em qualquer das situações, a violação da constituição só surge a título mediato, sendo apenas a legalidade infraconstitucional que
}

\footnotetext{
${ }^{3}$ Ibid., p. 69/70.
} 
directamente aparece violada pela decisão judicial, ainda que, reconheça-se que, se utilize nesta última situação um argumento de inconstitucionalidade para afastar a aplicação da norma devida."

Diante disso, com o oportuno auxílio das lições de Paulo Otero, pode-se conceituar coisa julgada inconstitucional como a decisão jurisdicional de mérito, proferida em sede de cognição exauriente, em que tenha havido a preclusão das possibilidades de sua impugnação dentro do processo (prévia constituição da coisa julgada formal) ${ }^{5}$, e que viole, dentre as situações apresentadas pelo autor, determinada norma constitucional.

Visto seu conceito, passa-se, para que se tenha a real noção dos limites do problema que será aqui tratado, à necessária distinção entre coisa julgada inconstitucional, simplesmente, e a coisa soberanamente julgada inconstitucional, a qual será, ela sim, objeto do presente estudo.

De fato, tal diferenciação mostra-se relevante tendo em vista que boa parte da doutrina que trata da chamada "flexibilização da coisa julgada inconstitucional" não tem a preocupação de direcionar a discussão aos casos em que, passado o prazo de dois anos do trânsito em julgado da sentença, a coisa julgada já se estabilizou, o que parece ser o ponto nodal de todo o problema.

Bem vistas as coisas, a res iudicata inconstitucional, simplesmente, pode, antes de findo prazo decadencial de dois anos, ser perfeitamente rescindida por meio de ação rescisória fundada no artigo 485, V, do Código de Processo Civil, abaixo transcrito:

\footnotetext{
“Art. 485. A sentença de mérito, transitada em julgado, pode ser rescindida quando:

(...)

V - violar literal disposição de lei;", (grifou-se)
}

\footnotetext{
${ }^{4}$ Ibid., p. 74 - grifou-se.

${ }^{5}$ DIDIER JR., Fredie et. al. Curso de Direito Processual Civil, volume 2. $5^{\mathrm{a}}$ ed. Salvador: Editora JusPODIVM, 2010, p. 411.
} 
Isso porque, a despeito da existência de algumas vozes sustentado entendimento diverso ${ }^{6}$, é amplamente majoritário na doutrina contemporânea e na jurisprudência atual ${ }^{7}$ que tal dispositivo legal autoriza a rescisão da coisa julgada por simples violação à norma jurídica, tenha ela matriz infraconstitucional ou constitucional, seja ela implícita ou explícita em nosso ordenamento jurídico.

O motivo para tal interpretação, conforme esclarece o processualista Ronaldo Cramer em obra específica sobre o tema, é que a lei, entendida como o texto normativo propriamente dito, não é passível de violação, mas somente as normas jurídicas que dela decorrem. Senão vejamos:

\footnotetext{
"A ação rescisória do inciso $\mathrm{V}$ não tem por finalidade remediar a violação da 'lei', mas sim reparar a infração à norma jurídica.

Com efeito, o que pode ser infringido por um pronunciamento judicial é a norma jurídica, e não a lei, que constitui o diploma legal onde estão inseridas as normas. Nenhum juiz cogita da aplicação de uma lei, mas da norma constante de uma lei. Por isso, a expressão "literal disposição de lei" é empregada no sentido de norma jurídica."
}

Também os princípios constitucionais implícitos, tidos como aqueles que não foram enunciados textualmente na Constituição, mas que decorrem da interpretação do sistema ou de um conjunto de dispositivos constitucionais ${ }^{9}$, acaso violados por uma sentença transitada em julgada, também dão ensejo à rescisão da coisa julgada por meio da ação rescisória por violação à "literal disposição de lei". Veja-se, nesse sentido, a lição de Teresa Arruda Alvim Wambier:

"Pensamos encartarem-se nesse conceito de lei também os princípios jurídicos, ainda que não estejam expressamente positivados. Estar-se-á, neste caso, em face de norma jurídica não escrita.

\footnotetext{
6 Confira-se, em sentido contrário ao entendimento a que se filia o presente trabalho, DINAMARCO, Maria Conceição Alves. Ação Rescisória. São Paulo: Atlas, 2004, p. 187/188 e RIZZARDO, Arnaldo. Limitações ao trânsito em julgado e desconstituição da sentença. Rio de Janeiro: Forense, 2009, p. 310/311.

${ }^{7}$ Cite-se, a título meramente exemplificativo, o seguinte julgado: STJ, Corte Especial, EREsp $\mathrm{n}^{\circ}$ 935.874/SP, Rel. Min. Arnaldo Esteves Lima, Brasília, julgamento de 17.06.2009.

${ }^{8}$ CRAMER, Ronaldo. Ação Rescisória por Violação da Norma Jurídica. Salvador: Editora JusPODIVM, 2012, p. 175.

9 BARROSO, Luís Roberto. Curso de direito constitucional contemporâneo: os conceitos fundamentais e a construção do novo modelo. São Paulo: Saraiva, 2009, p. 205.
} 
A primeira das razões, a que nos parece sem dúvida a mais importante, é a de que o desrespeito aos princípios é potencialmente muito mais danoso ao sistema do que a ofensa a um dispositivo legal.

Dissemos, nos itens iniciais deste trabalho, principalmente quando tratamos dos princípios jurídicos, que a tendência do direito contemporâneo é a de fazer com que os princípios integrem expressamente o texto constitucional. Como a Constituição Federal é, de certo, a "base" das demais leis no país, os princípios são mais do que isso: estão "por trás" de tudo, na origem do ordenamento escrito, e sua existência, embora frequentemente não estejam previstos de forma cabal e completamente expressa, se infere da leitura dos dispositivos das leis."10

Não se poderia deixar de conferir, ainda, o posicionamento de José Carlos Barbosa Moreira, o qual, de igual maneira, confere interpretação ampliativa ao artigo $485, \mathrm{~V}$, do CPC:

“'Lei', no dispositivo sob exame, há de entender-se em sentido amplo. Compreende, à evidência, a Constituição, a lei complementar, ordinária ou delegada, a medida provisória, o decreto legislativo, a resolução (Carta da República, art. 59), o decreto emanado do Executivo, o ato normativo baixado por órgão do Poder Judiciário (v.g., regimento interno: Constituição Federal, art. $96, \mathrm{n}^{\circ}$ I, letra $\left.a\right)^{, 11}$

Conclui-se, assim, que a rescisão à coisa julgada que viola toda e qualquer norma constitucional, seja ela decorrente de uma regra ou de um princípio, textualmente explícito ou implícito no texto da Carta Magna, pode, dentro do prazo de dois anos do trânsito em julgado da sentença rescindenda, ser desconstituída por meio da ação rescisória, sem que haja, atualmente, maiores discussões sobre o tema.

O problema não se dá, portanto, quando simplesmente a sentença transitada em julgado fere algum postulado constitucional, visto que, acaso não passado o prazo para seu ajuizamento, essa será passível de desconstituição por meio de ação rescisória.

Parece, de fato, que a grande divergência que se encontra atualmente instaurada na doutrina e jurisprudência brasileira, e que é objeto deste estudo, diz respeito à possibilidade de se rescindir a coisa julgada

\footnotetext{
${ }^{10}$ WAMBIER, Teresa Arruda Alvim. Recurso especial, recurso extraordinário e ação rescisória. $2^{\mathrm{a}}$ ed. São Paulo: Revista dos Tribunais, 2008, p. 501 - grifou-se.

${ }^{11}$ MOREIRA, José Carlos Barbosa. Comentários ao Código de Processo Civil, Lei no 5.869, de 11 de janeiro de 1973, vol. V: arts. 476 a 565. 14ª ed. Rio de Janeiro: Forense, 2008, p. 131.
} 
inconstitucional depois de esgotado o prazo decadencial para o ajuizamento da ação rescisória, previsto no artigo 495 do Código de Processo Civil.

Nesse contexto, conforme dita Alexandre Freitas Câmara, o fenômeno da coisa soberanamente julgada surge quando "consumada a decadência do direito à rescisão da sentença"12. Em outros termos, passado o prazo de dois anos do trânsito em julgado da sentença, não será mais possível o manejo da ação rescisória, único instrumento previsto pela Constituição Federal para a rescisão da coisa julgada em matéria cível, formando-se, assim, a coisa soberanamente julgada.

A partir daí, de acordo com o renomado autor, opera-se a "mais estável das situações jurídicas decorrentes de um ato jurisdicional, já que seu conteúdo não poderá ser alterado nem mesmo através de 'ação rescisória'.,"13

O presente trabalho investigará, desse modo, se é possível, por quais meios e em quais casos, rescindir a coisa soberanamente julgada que transgrida norma de hierarquia constitucional, afastando-se casuisticamente a aplicação da norma prevista no artigo 495 do CPC.

Feitos os esclarecimentos iniciais, passa-se à análise das principais correntes sobre o tema.

\section{I.2. A doutrina tradicional e o suposto caráter absoluto da coisa soberanamente julgada e da segurança jurídica}

Inicialmente, cumpre ao presente trabalho trazer à tona a posição da doutrina tradicional acerca do tema aqui tratado, segundo a qual a coisa julgada material, após passado o prazo definido em lei para o ajuizamento da ação rescisória, assumiria um caráter absoluto, impossibilitando, em qualquer caso, sua rescisão pelo Judiciário.

\footnotetext{
${ }^{12}$ CÂMARA, Alexandre. Lições de direito processual, volume II. $16^{\mathrm{a}}$ ed. Rio de Janeiro: Lumen Juris, 2011, p. 26.

${ }^{13}$ Ibid., p. 26.
} 
Nesse ponto, abram-se parênteses para esclarecer que a escolha do termo tradicional para qualificar tal parte da doutrina brasileira decorre de sua origem clássica, sendo certo que há inúmeros autores contemporâneos que defendem a absoluta intangibilidade da coisa julgada depois de esgotado o prazo previsto no artigo 495 do Código de Processo Civil.

Ainda a título preliminar, necessário expor que não se pretenderá tratar de todas as teses defendidas tanto pela doutrina tradicional quanto pela relativista, visto que tal esforço foge ao escopo do presente trabalho, mas apenas demonstrar as principais bases que apoiam os polos do debate acerca da possibilidade da desconstituição pelo Judiciário da coisa soberanamente julgada inconstitucional.

Em linhas gerais, tem-se que a doutrina tradicional defende que a mera possibilidade de desconstituição da coisa soberanamente julgada implicaria o esvaziamento do princípio da segurança jurídica e mesmo da própria função da jurisdição estatal, na medida em que, acaso aceita, os conflitos seriam eternizados na sociedade.

Sustenta que o efeito substitutivo da coisa julgada absorveria toda e qualquer nulidade ou injustiça porventura incorrida na sentença judicial que lhe serve de base, mesmo sua eventual incompatibilidade com normas da Constituição Federal, o que somente poderia ser impugnado por meio de ação rescisória. Incabível, no caso concreto, o manejo da ação rescisória, ou passado o prazo para seu ajuizamento, de nada poderia se socorrer a parte prejudicada.

Nesse sentido, noticia o processualista Eduardo Couture o dístico de Scassia, o qual bem representa a linha de tal filosofia, segundo o qual " $a$ coisa julgada faz do branco preto; origina e cria coisas; transforma o quadrado em redondo; altera os laços de sangue e transforma o falso em verdadeiro" $"$.

\footnotetext{
${ }^{14}$ COUTURE, Eduardo J. Fundamentos do Direito Processual Civil. Tradução de Benedicto Giaccobini. Campinas: RED Livros, 1999, fls. 329.
} 
Da mesma forma, citando exemplificativamente a clássica doutrina de Joaquim Ignácio de Carvalho, noticia Alexandre Câmara que havia, na doutrina brasileira, "quem afirmasse textualmente que 'a sentença que passa em julgado é havida por verdade" ${ }^{\prime 15}$.

Nota-se, desse modo, que a coisa soberanamente julgada foi originalmente tratada no Brasil como algo absolutamente intangível, um verdadeiro dogma. Nesse contexto, conforme informam Teresa Arruda Alvim Wambier e José Miguel Garcia Medina, "a tendência que vinha predominando, é a de que se fizesse prevalecer a coisa julgada, em detrimento de vários outros princípios constitucionais, como os da legalidade e da isonomia, principalmente." ${ }^{.16}$

É certo, todavia, que apesar de ser qualificado neste trabalho pelo adjetivo tradicional, o posicionamento no sentido da absoluta incindibilidade da coisa julgada encontra diversos adeptos dentre os autores contemporâneos, os quais duramente criticam as tentativas de se temperar a autoridade da res iudicata.

Arruda Alvim, por exemplo, ao censurar as doutrinas relativistas, defende a impossibilidade de, sem que haja uma reforma legislativa ampliando as hipóteses de cabimento da ação rescisória, se relativizar a coisa julgada:

"Trata-se, segundo nos parece, de uma tentativa de reconstrução dogmática do conceito de coisa julgada material, em verdadeira ruptura à concepção até então tida e assegurada pela Constituição Federal, de ser a res iudicata uma garantia constitucional soberana, imanente ao Estado de Direito e elevada à condição de cláusula pétrea.

Temos que a coisa julgada constitui garantia fundamental do Estado de Direito, e que sua relativização, em linha de princípio, deve ser evitada. De lege ferenda, defendemos a ampliação dos casos taxativamente previstos em lei de cabimento de ação rescisória, como forma de resolver uma ou outra situação potencialmente injusta, mas cuja existência, em nosso sentir, não justifica o mal maior, consistente na relativização da coisa julgada. Nossa posição é no sentido de que,

15 CÂMARA, Alexandre Freitas. Relativização da coisa julgada material. Disponível em $<$ http://www.unipli.com.br/direito/PASTAS_DOS_PROFESSORES/Laura_/Leonardo/relativizaca o_coisajulgada.pdf $>$. Acesso em 16.06.2012.

${ }^{16}$ WAMBIER, Teresa Arruda Alvim; MEDINA, José Miguel Garcia. O Dogma da Coisa Julgada: hipóteses de relativização. São Paulo: Revista dos Tribunais, 2003, p. 167. 
em linha de princípio, qualquer tentativa de sistematizar as hipóteses de relativizacão da coisa julgada deve ser afastada." ${ }^{17}$

De forma bem mais agressiva, Nelson Nery Junior, por sua vez, sustenta que a desconsideração da coisa julgada, ainda que excepcional, é inadmissível e inconciliável com o Estado Democrático de Direito, sendo, historicamente, instrumento de governos totalitaristas:

\begin{abstract}
"Interpretar a coisa julgada, se justa ou injusta, se ocorreu ou não, é instrumento do totalitarismo, de esquerda ou de direita, nada tendo a ver com democracia, com o Estado Democrático de Direito. Desconsiderar a coisa julgada é ofender a Carta Magna, deixando de dar aplicação ao princípio do Estado Democrático de Direito (CF. 1. ${ }^{\circ}$ caput)." ${ }^{, 18}$
\end{abstract}

Para o autor, o sistema jurídico deve conviver com a sentença contrária à Constituição, já que, segundo sua ótica, o risco da insegurança geral, causado pela mera permissão de se desconsiderar a coisa soberanamente julgada, é bem maior do que o risco de se proteger a injustiça em um caso específico. Para que devidamente se entenda sua lógica, imprescindível é a leitura do seguinte trecho de sua obra:

\begin{abstract}
"O sistema jurídico convive com a sentença injusta (...), bem como com a sentença proferida aparentemente contra a Constituição ou à lei (a norma, que é abstrata deve ceder sempre à sentença, que regula e dirige uma situação concreta). O risco político de haver sentença injusta ou inconstitucional no caso concreto parece ser menos grave do que o risco político de instaurar-se a insegurança geral com a relativização (rectius: desconsideração) da coisa julgada." $" 19$
\end{abstract}

Outro argumento utilizado por parte da doutrina contemporânea para rejeitar toda e qualquer hipótese de relativização da coisa soberanamente julgada inconstitucional é a de que, da mesma forma que uma decisão cristalizada pelo efeito do tempo pode, por vezes, violar a Constituição, é possível que a decisão que a rescinda também o faça.

\footnotetext{
${ }^{17}$ ALVIM, Arruda et al.. Comentários ao Código de Processo Civil. Rio de Janeiro: GZ Editora, 2012, p. 663 - destacou-se.

${ }^{18}$ NERY JUNIOR, Nelson. Teoria geral dos recursos. $6^{\mathrm{a}}$ ed. São Paulo: Editora Revista dos Tribunais, 2004, p. 510.

${ }^{19}$ Ibid., p. 507.
} 
As teses da relativização da coisa soberanamente julgada, nessa toada, criariam um mal maior, na medida em que abririam uma brecha para a livre desconstituição da res iudicata, sem garantir, no entanto, a realização da justiça no caso concreto por meio da nova decisão. Esse é o interessante raciocínio de Luiz Guilherme Marinoni e Sergio Cruz Arenhart:

\begin{abstract}
“As teses da 'relativização' não fornecem qualquer resposta para o problema da correção da decisão que substituiria a decisão qualificada pela coisa julgada. Admitir que o Estado-juiz errou no julgamento que se cristalizou implica em aceitar que ele pode errar novamente, quando a ideia de 'relativizar' a coisa julgada não traria qualquer benefício ou situação de justiça. (...)

É óbvio que uma teoria que conseguisse fazer com que todos os processos terminassem com um julgamento justo seria a ideal. Mas, na sua falta, não há dúvida que deve manter a atual concepção de coisa julgada material, sob pena de serem cometidas injustiças, muito maiores do que as pontuais e raras levantadas pela doutrina. ${ }^{, 20}$
\end{abstract}

Por fim, as teses relativistas são criticadas por se aterem apenas ao plano teórico, já que, segundo o juízo de Arnaldo Rizzardo, não oferecem "qualquer indicação prática sobre a forma de se viabilizar a prevalência da ordem constitucional."21

É de se reconhecer que ao menos a crítica acima reproduzida é procedente, já que a grande maioria dos autores que defende a relativização da coisa julgada, o faz apenas criticando a ideia de sua absoluta intangibilidade, sem, porém, tentar traçar os limites em que essa relativização deverá ocorrer.

Por esse motivo, como se verá mais a frente, o presente estudo busca suprir essa deficiência das teses relativistas, na medida em que, valendo-se das técnicas de resolução de conflitos normativos, constrói parâmetros objetivos para orientar o Poder Judiciário na sua decisão de, excepcionalmente, desconstituir ou não a coisa soberanamente julgada inconstitucional.

\footnotetext{
${ }^{20}$ MARINONI, Luiz Guilherme; ARENHART, Sergio Cruz. Processo de conhecimento, v. 2. $9^{\mathrm{a}}$ ed. São Paulo: Editora dos Tribunais, 2011, p. 688/689.

${ }^{21}$ RIZZARDO, Arnaldo. Limitações ao trânsito em julgado e desconstituição da sentença., p. 129.
} 


\section{I.3. Críticas ao entendimento tradicional - a inexistência de norma jurídica absoluta}

Para que se desconstrua a principal base em que se funda a doutrina tradicional - qual seja, a absoluta impossibilidade de se rescindir a coisa soberanamente julgada -, é preciso que, primeiramente, sejam identificadas as normas constitucionais e infraconstitucionais que impõem sua proteção, bem como sejam elas classificadas como regras ou princípios.

Nesse sentido, Luís Roberto Barroso, seguindo a classificação trazida por Ronald Dworkin e Robert Alexy, leciona que a principal distinção entre regras e princípios reside no seu modo de aplicação. As regras, segundo o autor, prescrevem comandos objetivos, na medida em que expressam diretamente um preceito, uma proibição ou uma permissão. São aplicadas, assim, na modalidade do "tudo ou nada", isto é, "ocorrendo o fato descrito em seu relato ela deverá incidir, produzido o efeito previsto". ${ }^{22}$

Por sua vez, os princípios indicam uma direção a ser seguida, servindo, muitas vezes, apenas de referencial para o intérprete. Não prescrevem, necessariamente, uma conduta específica a ser obedecida, já que sua realização pode ser alcançada de diversas maneiras ${ }^{23}$. Os princípios são aplicados, assim, por meio da técnica da ponderação, "de acordo com a dimensão de peso que assumem na situação específica." ${ }^{24}$

Veja-se por todos, nos ensinamentos de Ana Paula de Barcellos, uma forma bastante simples de se diferenciar os dois comandos normativos:

"as regras descrevem comportamentos, sem se ocupar diretamente dos fins que as

22 BARROSO, Luís Roberto. BARROSO, Luís Roberto. Curso de direito constitucional contemporâneo: os conceitos fundamentais e a construção do novo modelo., p. 206/207.

${ }^{23}$ BARCELLOS, Ana Paula de. Ponderação, racionalidade e atividade jurisdicional. Rio de Janeiro: Renovar, 2005, p. 175.

${ }^{24}$ BARROSO, Luís Roberto. BARROSO, Luís Roberto. Curso de direito constitucional contemporâneo: os conceitos fundamentais e a construção do novo modelo., p. 208. 
estados ideais, objetivos a serem alcançados, sem explicitarem necessariamente as ações que devem ser praticadas para obtenção desses fins." 25

Desse modo, entende-se que a norma insculpida no artigo $5^{\circ}$, XXXVI da Constituição Federal ${ }^{26}$, a qual garante a intangibilidade da coisa julgada, tem natureza de princípio, e não de regra, na medida em que indica um fim a ser seguido na maior medida possível - a proteção, sempre que possível, da coisa julgada material - e não um comando definitivo, realizável somente por uma conduta específica.

Tanto é assim, que se admite de forma pacífica que tal princípio fundamental, assim como ocorre com outros previstos no artigo $5^{\circ}$ da Carta Constitucional, sofra limitações impostas pelo legislador infraconstitucional, o que pode ser exemplificado pelas regras do Código de Processo Civil que, ao regular a ação rescisória, preveem as formas de rescisão da coisa julgada material ${ }^{27}$.

Desse modo, sendo a garantia fundamental da intangibilidade da coisa julgada um princípio, não pode ela, em razão de sua própria essência, ser considerado absoluto, ao menos em sua área não nuclear. Isso porque, conforme já exposto, a incidência dos princípios, no que diferem fundamentalmente das regras, não ocorre em termos de tudo-ou-nada, já que sofrem constantes limitações de outras normas na medida em que, com elas, entrem em rota de colisão ${ }^{28}$.

Também a segurança jurídica, a qual protege, em uma de suas dimensões, a inalterabilidade da coisa julgada ${ }^{29}$, é um princípio

\footnotetext{
${ }^{25}$ BARCELLOS, Ana Paula de. Ponderação, racionalidade e atividade jurisdicional., p. 169/170.

${ }^{26}$ Art. $5^{\circ}$. (...). XXXVI - a lei não prejudicará o direito adquirido, o ato jurídico perfeito e a coisa julgada;

${ }^{27}$ Nesse sentido, o magistério do Professor José Afonso da Silva: “A proteção constitucional da coisa julgada não impede, contudo, que a lei preordene regras para a sua rescisão mediante atividade jurisdicional." SILVA, José Afonso da. Curso de Direito Constitucional Positivo. $32^{\mathrm{a}}$ ed. São Paulo: Malheiros, 2009, p. 436/437.

${ }^{28}$ Conforme aponta Luís Roberto Barroso, “a colisão de princípios, portanto, não é só possível, como faz parte da lógica do sistema, que é dialético. Por isso a sua incidência não pode ser posta em termos de tudo ou nada, de validade ou invalidade. (...) A aplicação dos princípios se dá, preponderantemente, mediante ponderação". BARROSO, Luís Roberto. Interpretação $e$ aplicação da Constituição. $6^{\text {a }}$ edição. São Paulo: Saraiva, 2008, p. 355 - grifou-se.

${ }_{29}$ Nas palavras de José Gomes Canotilho, "as refrações mais importantes do princípio da segurança jurídica são as seguintes: (...) (2) relativamente a actos jurisdicionais - inalterabilidade
} 
constitucional implícito, não podendo, pelos mesmos motivos acima expostos, ser-lhe conferida a qualidade de absoluto em nosso ordenamento jurídico. Nesse sentido é a irretocável lição de Humberto Theodoro Jr. e Juliana Cordeiro Faria:

"Nenhum princípio no campo do direito, nem mesmo nos domínios constitucionais, pode ser visto e aplicado como absoluto. A própria segurança jurídica, ainda que mereça a qualificação de elemento natural e necessário do Estado de direito democrático, não escapa à relatividade inerente à sistemática dos princípios de direito." 30

Não há, desse modo, maiores problemas em se defender a relatividade dos princípios constitucionais que visam proteger a intangibilidade da coisa soberanamente julgada, tendo em vista que é da própria natureza de tais enunciados normativos que eles se retraiam caso entrem em confronto com outras normas de matriz de constitucional.

Contudo, sabe-se que a estabilização da coisa julgada, a qual ocorre após passado o prazo de dois anos do trânsito em julgado da decisão que lhe serviu de base, é imposta por meio de norma que, apesar de sua hierarquia infraconstitucional, tem natureza de regra. É o que se extrai do já mencionado artigo 495 do Código de Processo Civil.

$\mathrm{O}$ assunto será mais profundamente tratado à frente, mas, por ora, basta consignar que não se faz possível, de antemão, afirmar que em nenhuma hipótese poderá ser casuisticamente afastada a aplicação da regra insculpida no referido enunciado normativo em virtude do eventual vício de inconstitucionalidade, muito embora seja ela, em tese, perfeitamente constitucional.

Com efeito, conforme será detalhado em momento oportuno, não obstante rara a ocorrência de um conflito em concreto entre uma regra infraconstitucional válida em tese e perfeitamente subsumível ao caso e

do caso julgado.”. CANOTILHO, J. J. Gomes. Direito constitucional e teoria da Constituição. $7^{\mathrm{a}}$ Edição. Coimbra: Almedina, 2000, p. 257.

${ }^{30}$ THEODORO JR., Humberto; FARIA, Juliana Cordeiro de. Reflexões sobre o princípio da intangibilidade da coisa julgada e sua relativização. In: NASCIMENTO, Carlos Valder do; DELGADO, José Augusto (Org.). Coisa julgada inconstitucional. $2^{\mathrm{a}}$ ed. Belo Horizonte: Fórum, 2008, p. 169. 
uma regra (ou o núcleo de um princípio) da Constituição, ela é plenamente possível e tem-se, com alguma frequência, sido observada na prática. Nesse caso, como se verá, necessária será a declaração de inconstitucionalidade, no caso concreto, da norma produzida pela incidência do enunciado infraconstitucional. $^{31}$

Assim, muito embora fuja à sua essência, tem-se que também as regras, principalmente as infraconstitucionais, como a do artigo 495 do diploma processual, podem ser afastadas no caso concreto, de modo a permitir, adiante-se desde já, a desconstituição da coisa soberanamente julgada.

É falsa, portanto, a premissa em que se fundamenta toda doutrina tradicional, qual seja o caráter absoluto das normas que impõem a intangibilidade do caso soberanamente julgado em nosso ordenamento. Afinal, como bem salientado pelo eminente Ministro do Supremo Tribunal Federal, Celso de Mello, quando do julgamento do MS 23.452/RJ, "não há, no sistema constitucional brasileiro, direitos ou garantias que se revistam de caráter absoluto"32.

\section{I.4. A doutrina moderna e a necessária relativização da coisa julgada inconstitucional}

A doutrina relativista, no Brasil, surgiu da indignação de alguns juristas que apontavam o dogma da coisa soberanamente julgada como um manto protetor de graves injustiças e inconstitucionalidades.

Passou-se, com ela, a questionar o caráter absoluto do princípio da intangibilidade da coisa julgada, bem como da segurança jurídica, que o justifica. Face o convívio (e a eventual tensão) de tais postulados normativos com valores constitucionais, haveria casos, segundo alguns, que

\footnotetext{
${ }^{31}$ BARCELLOS, Ana Paula de. Ponderação, racionalidade e atividade jurisdicional., p. 201/204.

32 STF, MS 23452/RJ, Rel. Ministro Celso de Mello, Tribunal Pleno, Brasília, julgamento de 16.09.1999.
} 
a coisa julgada deveria ceder $^{33}$. Segundo outros, a coisa julgada seria sempre insustentável acaso violasse determinada norma de matriz constitucional $^{34}$ ou incorresse em alguma injustiça ${ }^{35}$.

Deriva de tal doutrina, ainda, a ideia de que a absoluta intangibilidade da res iudicata, mesmo nos casos em que a decisão que the serve de fundamento seja, de alguma forma, injusta ou viole norma da Constituição, é incoerente com o Estado Democrático de Direito, bem como com a noção, a ele inerente, de supremacia constitucional.

Nesse sentido, defendem os relativistas que as decisões judiciais transitadas em julgado, da mesma forma que os demais atos emanados dos outros dois Poderes da República - a lei, lato sensu, e o ato administrativo não estariam imunes ao seu permanente controle de conformidade com a Constituição Federal. Sendo inconstitucionais, deveriam ser extirpadas do ordenamento jurídico.

Vistos os principais argumentos levantados pela doutrina moderna, pode-se, sem que se tenha, de novo, a pretensão de se abarcar todas as teses que admitam a relativização da coisa julgada, o que seria inviável face aos inúmeros trabalhos publicados sobre o tema, dividir as correntes relativistas a partir de três critérios. O delineamento de tal panorama geral será importante para que, em seguida, sejam formuladas as críticas aos exageros que incorrem parte da doutrina relativista.

Em primeira ordem, divergem os autores quanto às razões que justificam a possibilidade de se desconstituir a coisa julgada violadora à norma constitucional.

Há quem defenda, como o faz Humberto Theodoro $\mathrm{Jr}^{36}$, no que é acompanhado por Gustavo Tavares Borba ${ }^{37}$, que o artigo $5^{\circ}$, XXXVI da

\footnotetext{
${ }^{33}$ DINAMARCO, Cândido Rangel. Relativizar a coisa julgada. Revista da Procuradoria do Estado de São Paulo. São Paulo, nº 55/56, janeiro/dezembro de 2001, p. 31/78.

34 THEODORO JR., Humberto; FARIA, Juliana Cordeiro de. Reflexões sobre o princípio da intangibilidade da coisa julgada e sua relativização., p. 181/182.

${ }^{35}$ ARMELIN, Donaldo. Flexibilização da coisa julgada. In: NASCIMENTO, Carlos Valder do; DELGADO, José Augusto (Org.). Coisa julgada inconstitucional. $2^{\mathrm{a}}$ ed. Belo Horizonte: Fórum, 2008, p. 224/226.
} 
Constituição Federal protegeria a coisa julgada apenas dos efeitos de uma nova lei. A norma constitucional, desse modo, vincularia apenas o Legislativo, estando o Poder Judiciário obrigado a respeitar a coisa julgada apenas em razão de disposições infraconstitucionais.

Segundo tal corrente, assim, para solucionar o enigma da coisa julgada inconstitucional, não haveria porque se socorrer da técnica de ponderação, na medida em que, nesse caso, estariam em confronto normas de hierarquia diferentes, devendo sempre prevalecer a Constituição e ser desconstituída a res iudicata.

Com efeito, conforme dita Pedro Eduardo Pinheiro Antunes de Siqueira $^{38}$, a solução para a antinomia de normas causada pela coisa julgada inconstitucional seria bastante simples. Bastaria, segundo tal parte da doutrina, que o intérprete se utilizasse de regra tradicional de hermenêutica, segundo a qual a norma de hierarquia maior prevalece sobre a menor, para que decida sempre pela modificação da decisão judicial nociva à Constituição.

De modo oposto, posiciona-se a doutrina que, a despeito de enxergar a coisa julgada como uma garantia constitucional, entende que ela deve estar em equilíbrio com as demais normas que integram a Constituição. Utilizando-se do método da ponderação, assim, bem como dos princípios da razoabilidade e da proporcionalidade, haverá casos em que a coisa julgada

${ }^{36}$ THEODORO JR., Humberto; FARIA, Juliana Cordeiro de. A coisa Julgada Inconstitucional $e$ os Instrumentos Processuais para seu Controle. In Revista da AGU. Brasília, nº 09, abr./2001. Disponível

em $<$ http://www.agu.gov.br/sistemas/site/TemplateTexto.aspx?idConteudo=104461\&Id_site=1115\&o rdenacao $=1>$. Acesso em 12.08.2012.

37 “ $\mathrm{O}$ inciso XXXVI do art. $5^{\circ}$ da $\mathrm{CF} / 88$ apenas protegeu o teor da coisa julgada contra uma modificação legislativa que afetasse o fundamento da decisão transitada em julgado. Não impediu, por conseguinte, a modificação do instituto da coisa julgada, como nos casos em que se permite a sua desconstituição". TAVARES BORBA, Gustavo. Embargos Desconstitutivos - Estudo sobre sua Constitucionalidade. In Revista da Procuradoria Geral do Estado do Rio de Janeiro. Rio de Janeiro, $n^{\circ} 54,2001$, p. 79.

38 "A vantagem do sistema brasileiro consiste em não se incorrer em subjetivismo ao se efetuar, pelo subprincípio da proporcionalidade em sentido estrito ou racionalidade, a ponderação de interesses. Basta, ao contrário, aplicar a regra de hermenêutica para a solução de antinomias, pela qual a norma de hierarquia maior prevalece sobre aquela menor. Trata-se de um raciocínio claro e objetivo. Não há, dessa maneira, que se ponderar a segurança jurídica com a justiça da questão em tela. Em qualquer caso, para que seja justa uma dada decisão transitada em julgado, necessária será sua conformação com os princípios e regras do Texto Fundamental.”. SIQUEIRA, Pedro Eduardo Pinheiro Antunes de. A coisa julgada inconstitucional. Rio de Janeiro: Renovar, 2006, p. 224/226. 
deverá ser relativizada. Nesse sentido é que se posta, por exemplo, Alexandre Freitas Câmara ${ }^{39}$.

Ademais, é possível separar os doutrinadores relativistas pelos seus entendimentos quanto à consequência da inconstitucionalidade da sentença que serve de base para a coisa julgada.

Em sua grande maioria, consoante a teoria majoritariamente adotada no Brasil da nulidade do ato jurídico inconstitucional, posicionam-se os autores relativistas no sentido de que a inconstitucionalidade da sentença teria o condão de invalidar a coisa julgada sobre ele formada, permitindo, por consequência, a sua rescisão.

Alguns poucos, porém, como é o caso de Teresa Arruda Alvim Wambier, José Miguel Garcia Medina ${ }^{40}$, Ivo Dantas ${ }^{41}$ e Carlos Henrique Soares $^{42}$, sustentam que a sentença eivada do vício de inconstitucionalidade seria, na verdade, inexistente, motivo pelo qual a coisa julgada que a acoberta, nesses casos, sequer teria se formado.

Por fim, é controverso na doutrina moderna se apenas a inconstitucionalidade da decisão judicial em que se baseia a coisa julgada seria motivo hábil para sua rescisão, ou, por outro lado, se também a injustiça da decisão judicial teria tal efeito sobre a res iudicata. Em favor da primeira corrente, citem-se, a título meramente exemplificativo, os autores Cassio Scarpinella Bueno ${ }^{43}$ e Alexandre Freitas Câmara ${ }^{44}$. Em favor da segunda, por sua vez, é como se posiciona Donaldo Armelin ${ }^{45}$.

\footnotetext{
${ }^{39}$ CÂMARA, Alexandre Freitas. Relativização da coisa julgada material.

${ }^{40}$ WAMBIER, Teresa Arruda Alvim; MEDINA, José Miguel Garcia. O Dogma da Coisa Julgada: hipóteses de relativização., p. 31.

${ }^{41}$ DANTAS, Ivo. Coisa julgada inconstitucional: declaração judicial de inexistência. In: NASCIMENTO, Carlos Valder do; DELGADO, José Augusto (Org.). Coisa julgada inconstitucional. $2^{\text {a }}$ ed. Belo Horizonte: Fórum, 2008, p. 285.

${ }^{42}$ SOARES, Carlos Henrique. Coisa julgada constitucional. Coimbra: Almedina, 2009, p. 235.

${ }^{43}$ BUENO, Cassio Scarpinella. Curso sistematizado de direito processual civil: procedimento comum: ordinário e sumário, 2: tomo I. $2^{a}$ ed. São Paulo, Saraiva, 2009, p. 403.

${ }^{44}$ CÂMARA, Alexandre Freitas. Relativização da coisa julgada material.

${ }^{45}$ ARMELIN, Donaldo. Flexibilização da coisa julgada., p. 224/226 .
} 


\section{I.5. Críticas aos exageros da doutrina relativista - a indispensável proteção à garantia fundamental à coisa soberanamente julgada}

Não obstante já se tenha visto que a doutrina relativista parte de uma premissa perfeitamente válida, qual seja a impossibilidade de se conferir a qualquer norma em nosso sistema legal, seja ela regra ou princípio, caráter absoluto, é inegável que muitos de seus autores incorrem em diversos exageros.

De início, tendo em vista a importância do tema para as próximas ideias a serem desenvolvidas no presente trabalho, necessário que se desconstitua a noção de que a vinculação do Poder Judiciário à intangibilidade da coisa julgada não teria fundamento constitucional, mas somente na legislação infraconstitucional

Dúvidas não há de que o artigo $5^{\circ}$, XXXVI, da Constituição Federal tem importante função no Direito Intertemporal brasileiro, qual seja o de fixar como limite à retroatividade das leis o direito adquirido, o ato jurídico perfeito e a coisa julgada, protegendo-os de atos normativos supervenientes que venham a prejudicá-los.

Assim, o aludido dispositivo constitucional dá aos indivíduos a relativa certeza de que suas relações jurídicas reguladas sob o império de uma determinada norma perdurarão ainda quando esta seja por outra substituída ${ }^{46}$.

Todavia, ao dispor que "a lei não prejudicará (...) a coisa julgada", estaria o enunciado normativo em comento apenas se referindo à lei nova, editada após a formação da res iudicata? O Judiciário, ao aplicar uma lei antiga ao caso concreto, poderia, então, livremente desconstituir a coisa julgada sem que tal fato importasse em violação ao artigo $5^{\circ}$, XXXVI? Não estaria aqui, do mesmo modo, a lei sendo utilizada de forma a prejudicar a coisa julgada, conforme proíbe a Constituição?

\footnotetext{
${ }^{46}$ SILVA, José Afonso da. Curso de Direito Constitucional Positivo., p. 432.
} 
Por certo, não se pode aceitar que se exclua do âmbito de incidência da norma em questão as hipóteses nas quais o Judiciário, ou mesmo o Executivo, aplique a lei de modo a prejudicar a decisão judicial estabilizada pelo efeito do tempo. Estar-se-ia, nesse caso, restringindo, indevidamente, a eficácia da norma fundamental.

Com efeito, extrai-se do próprio texto do dispositivo constitucional em comento que também a lei antiga, tida como aquela editada anteriormente à formação da coisa julgada, não deverá prejudicar a res iudicata, cumprindo ao magistrado, ao aplicá-la, se abster de alterar uma decisão judicial estabilizada pelos efeitos da coisa julgada material.

Desse modo, ao contrário do sustentado por alguns, tendo em vista que o Judiciário (assim como o Executivo) tem, por definição, a função de aplicar a lei ao caso concreto, está ele claramente vinculado a respeitar a autoridade da coisa julgada, sob pena de violação à aludida norma constitucional.

Tal interpretação, vale dizer, está em perfeita consonância com o princípio hermenêutico da máxima efetividade das normas constitucionais, o qual dispõe que, em caso de dúvida, deve o intérprete da Constituição sempre realizar uma interpretação expansiva, e não restritiva, de suas normas, principalmente daquelas que dispõem acerca de direitos fundamentais ${ }^{47}$, como se dá com o enunciado em questão.

Além disso, acrescente-se que, à luz de já invocada lição de Gomes Canotilho, o princípio da intangibilidade da coisa julgada frente a um novo pronunciamento judicial se apresenta como um dos mais importantes corolários do princípio constitucional da segurança jurídica. Relembre-se, a propósito, as palavras do prestigiado constitucionalista português:

\footnotetext{
"As refracções mais importantes do princípio da segurança jurídica são as seguintes: (1) relativamente a actos normativos - proibição de normas retroactivas restritivas de direitos ou interesses juridicamente protegidos; (2) relativamente a actos jurisdicionais - inalterabilidade do caso julgado; (3)
}

\footnotetext{
${ }^{47}$ CANOTILHO, J. J. Gomes. Direito constitucional e teoria da Constituição., p. 1.224.
} 
relativamente a actos da administração - tendencial estabilidade dos casos decididos através de actos administrativos constitutivos de direitos." ${ }^{48}$

Por fim, cumpre aqui rebater argumento formulado pelo jurista Ivo $\operatorname{Dantas}^{49}$, o qual sustenta que acaso admitida a matriz constitucional do princípio da intangibilidade do caso julgado, as normas processuais que regulam o instituto da ação rescisória, por preverem hipóteses de rescisão da coisa julgada, deveriam ser consideradas inconstitucionais.

Rememore-se, aqui, por essencial, que a norma jurídica insculpida no artigo $5^{\circ}$, XXXVI, da Constituição Federal tem natureza de princípio, de modo que, em razão de sua relativa indeterminação de sentido, admite que, até certa medida, restrições sejam a ela criadas.

Ademais, sabe-se que a ação rescisória é mencionada no texto constitucional de forma expressa (conforme arts. 102, I, j, 105, I, e, e 108, I, $b$ ). Desse modo, tendo ela sido, historicamente, utilizada como o remédio processual apto a desconstituir a coisa julgada material ${ }^{50}$, parece claro que a própria Constituição admite que, por meio deste instrumento, seja excepcionado o referido princípio.

Por qualquer ângulo que se olhe a questão, portanto, não há como negar que o princípio da imodificabilidade do caso julgado frente a novos atos jurisdicionais tem sua sede no texto constitucional; seja porque está inequivocamente insculpido no artigo $5^{\circ}$, XXXVI, da Lei Fundamental, seja porque é decorrente do princípio constitucional implícito da segurança jurídica.

\footnotetext{
${ }^{48}$ Ibid., p. 257 - destacou-se.

${ }^{49}$ Conforme entende o autor, "o conteúdo do inc. XXXVI do art. $5^{\circ}$, apenas põe a coisa julgada a salvo de lei nova, tanto que, em nosso sistema, o instituto da Ação Rescisória tem plena aceitação, não se duvidando de sua constitucionalidade.". DANTAS, Ivo. Constituição \& Processo. Curitiba: Juruá, 2003, p. 216 - grifou-se.

${ }^{50}$ Conforme noticia Pontes de Miranda, a ação rescisória já estava prevista nas Ordenações Afonsinas, Manuelinas e Filipinas. Contudo, sua legislação apenas foi sistematizada no Brasil com o advento do Código de Processo Civil de 1939, que a regulamentava por meio de seus artigos 798 a 801. MIRANDA, Pontes de. Tratado da ação rescisória das sentenças e de outras decisões. $5^{\mathrm{a}}$ ed. Rio de Janeiro: Forense, 1976, p. 100/103. Hoje, como se sabe, a ação rescisória é prevista em disposições originais do atual CPC, em vigor desde $1^{\circ}$ de Janeiro de 1974.
} 
Além disso, é de se contestar o entendimento ventilado por alguns doutrinadores no sentido de que a injustiça da decisão, sozinha, seria motivo o suficiente para se afastar a coisa soberanamente julgada.

Para além das infindáveis e inconclusivas discussões acerca da noção de justiça, não se pode admitir que tal valor, que possui um conceito tão vago quanto amplo, seja utilizado como parâmetro para a desconstituição da coisa soberanamente julgada.

A estabilidade da res iudicata, entendida como garantia constitucional “indispensável ao Estado Democrático de Direito e à efetividade do direito fundamental de acesso ao Poder Judiciário",51, não pode ser arbitrariamente abalada, devendo apenas ser considerada razoável a rescisão do ato jurisdicional transitado em julgado quando motivos particularmente relevantes apontem nesse sentido ${ }^{52}$.

Ademais, conforme já se viu e se aprofundará à frente, a noção de relatividade do caso soberanamente julgado implica no afastamento casuístico da norma derivada do artigo 495 do Código de Processo Civil, muito embora seja ela, em tese, perfeitamente válida e constitucional. A não aplicação de uma regra válida em abstrato e pertinente ao caso concreto, como ocorre nas hipóteses de desconstituição da coisa soberanamente julgada inconstitucional, porém, deve ser medida de extrema excepcionalidade, pois "poderá acarretar na ruptura do sistema do Estado de direito" $" 53$.

Por esses motivos, entende-se que a desconstituição da coisa soberanamente julgada é um radical desvio de nosso sistema legal, não podendo, por isso, ter como justificativa a injustiça da decisão, que pode significar, conforme a cognição subjetiva do intérprete, desde sua inconstitucionalidade ou ilegalidade, até sua mera incongruência com a verdade real.

\footnotetext{
${ }^{51}$ MARINONI, Luiz Guilherme. O princípio da segurança jurídica dos atos jurisdicionais (a questão da coisa julgada material). Revista Jurídica. São Paulo, n. 317, p. 16, 16.03.2002.

${ }_{52}$ CANOTILHO, J. J. Gomes. Direito constitucional e teoria da Constituição., p. 264.

${ }^{53}$ BARCELLOS, Ana Paula de. Ponderação, racionalidade e atividade jurisdicional., p. 204.
} 
Não merece prosperar, ainda, sob pena de esvaziamento da garantia constitucional da estabilidade da coisa julgada, o posicionamento de alguns autores segundo o qual a coisa julgada simplesmente não se formaria acaso a decisão judicial que lhe servisse de base infringisse norma da Constituição Federal. Isso porque, segundo sustentam, seria a sentença violadora à norma constitucional, nesse caso, inexistente.

Conforme bem aponta em sua obra Pedro Eduardo Pinheiro Antunes de Siqueira ${ }^{54}$, todavia, não se pode confundir os planos da existência, validade e eficácia do ato jurídico. $\mathrm{Na}$ medida em que presentes os elementos essenciais da sentença, quais sejam o relatório, a fundamentação e o dispositivo, deve ser ela considerada, ao menos, como um ato juridicamente existente. Assim, transitada em julgado a decisão judicial final e de mérito, ainda que inconstitucional, não há como negar que a coisa julgada se formará.

A eventual inconstitucionalidade da decisão judicial, portanto, poderá, observadas certas circunstâncias, comprometer a validade da coisa julgada que sobre ela se formou (e não sua existência), o que permitirá sua desconstituição por meio de ação rescisória. Trata-se de entendimento já pacificado na doutrina nacional ${ }^{55}$.

De fato, certo é que a compreensão de que a coisa julgada não se formará caso a decisão que a embase viole a Constituição é contraditória com a natureza e a função do próprio instituo. Não teria sentido a previsão constitucional da coisa julgada, a qual tem, como uma de suas principais finalidades, proteger o ato jurisdicional transitado em julgado de posteriores questionamentos sobre suas irregularidades, se toda e qualquer incompatibilidade com a própria Constituição implicasse em sua inexistência.

\footnotetext{
${ }^{54}$ SIQUEIRA, Pedro Eduardo Pinheiro Antunes de. A coisa julgada inconstitucional., p. 133/134.

${ }^{55}$ Nesse sentido, ensina Luís Roberto Barroso que "norma inconstitucional é norma inválida, por desconformidade com regramento superior, por desatender os requisitos impostos pela norma maior.”. BARROSO, Luís Roberto. O controle de constitucionalidade no direito brasileiro: exposição sistemática da doutrina e análise crítica da jurisprudência. $3^{a}$ ed. São Paulo: Saraiva, 2008, p. 13.
} 
Também por isso não se pode acatar a posição majoritária da doutrina relativista no sentido de que coisa soberanamente julgada inconstitucional deveria ser, em todas as hipóteses de sua configuração, desconstituída, conforme se dá com os atos emanados pelos demais Poderes.

Em razão da proteção especial conferida à intangibilidade da coisa soberanamente julgada pela Constituição, assim como por normas infraconstitucionais perfeitamente válidas em tese, como se disse, a sua rescisão não pode ser automática à constatação de sua incongruência com determinada norma constitucional.

Além disso, conforme visto, não é demais acrescentar que da mesma forma que as normas constitucionais e infraconstitucionais que têm como finalidade a proteção à imutabilidade da coisa soberanamente julgada não são absolutas, também não a são aquelas que eventualmente entrarão com ela em conflito no caso concreto.

Desse modo, a robustecer o entendimento aqui veiculado, imaginese, por exemplo, ser possível a desconstituição da coisa soberanamente julgada se a decisão que a embasasse infringisse, em alguma medida, o princípio constitucional da dignidade da pessoa humana. Além do fato do seu campo de incidência ser demasiadamente amplo, sabe-se que os efeitos que tal princípio fundamental produzirá no caso concreto são, até certo ponto, indeterminados, de modo a ser possível, em diversos casos, que o princípio da dignidade da pessoa humana seja utilizado validamente para embasar os dois lados de uma mesma discussão ${ }^{56}$.

Assim é que admitir que qualquer violação a determinada norma da Carta Magna, no que está incluído o desrespeito aos seus princípios fundamentais, implicasse na automática desconstituição da coisa soberanamente julgada, teria o condão de esvaziar, por completo, a proteção constitucional a tal instituto, o que, por certo, não pode ser admitido em nosso sistema. Tornar-se-ia verdadeiro, nesse caso, o alarde tão propagado

\footnotetext{
${ }^{56}$ BARCELLOS, Ana Paula de. Ponderação, racionalidade e atividade jurisdicional. p. 174/175.
} 
pela doutrina tradicional, no sentido de que os conflitos submetidos ao Judiciário se eternizariam no tempo.

Nesse passo, a corroborar o entendimento aqui ventilado segundo o qual a violação à Constituição por parte da decisão judicial não tem como efeito automático a rescisão da coisa julgada que a protege, ante sua especial proteção pela Carta constitucional, a jurisprudência do C. Supremo Tribunal Federal tem se firmado no sentido de que o efeito ex tunc gerado pela nulidade da norma declarada inconstitucional em controle concentrado, não atingirá, em regra, as coisas julgadas que se formaram a partir de sentenças que a aplicaram ${ }^{57}$.

Com a ressalva de que, como será adiante visto, é possível - ainda que excepcionalmente - a rescisão da coisa soberanamente julgada por ter ela se baseado em lei inconstitucional, tome-se mais uma vez a precisa lição do Ministro Celso de Mello, agora quando do julgamento do RE 594350 / RS:

\footnotetext{
"A decisão do Supremo Tribunal Federal que haja declarado inconstitucional determinado diploma legislativo em que se apóie o título judicial, ainda que impregnada de eficácia "ex tunc", como sucede com os julgamentos proferidos em sede de fiscalização concentrada (RTJ 87/758 - RTJ 164/506-509 - RTJ 201/765), detém-se ante a autoridade da coisa julgada, que traduz, nesse contexto, limite insuperável à força retroativa resultante dos pronunciamentos que emanam, "in abstracto", da Suprema Corte. ${ }^{58,}$
}

Com efeito, a desconstituição do caso soberanamente julgado, em virtude de sua enorme importância, é uma exceção em nosso sistema jurídico, e como tal deve ser encarada. E é nessa medida que o alerta à generalização, como o abaixo reproduzido, deve ser melhor difundido em nossa doutrina:

"É dizer de forma bem direta: não se pode, justamente por causa da influência do 'modelo constitucional do direito processual civil', sustentar a aplicação

\footnotetext{
57 Nesse sentido os seguintes precedentes: STF, RE 592912/RS, Rel. Min. Celso de Mello, Brasília, julgamento de 24.05.2010; STF, RE 473715 AgR/CE, Rel. Min. Carlos Britto, Primeira Turma, Brasília, julgamento de 26.04.2007 e RE 431014 AgR /RN, Rel. Min. Sepúlveda Pertence, Primeira Turma, Brasília, julgamento de 24.04.2007.

${ }^{58}$ STF, RE 594350 / RS, Rel. Min. Celso de Mello, Brasília, julgamento de 25.05.2010.
} 
indiscriminada, até mesmo generalizada da tese da 'relativização da coisa julgada'. Uma tal aplicação não pode ser aceita." ${ }^{.59}$

Em suma, em virtude da fundamental importância da segurança e estabilidade das relações jurídicas em nossa sociedade, a qual se realiza, dentre outros meios, pela proteção às decisões transitadas em julgado, fazse necessário estabelecer limites à doutrina que defende a (eufemisticamente) chamada "relativização da coisa julgada inconstitucional".

Nesse passo, conforme uma análise mais acurada do fenômeno poderá demonstrar, para a desconstituição da coisa soberanamente julgada, necessário se faz que o Poder Judiciário profira uma decisão contra legem, afastando, no caso concreto, a aplicação da norma jurídica contida no artigo 495 do Código de Processo Civil. A esse exame se dedicará o próximo Capítulo.

\footnotetext{
${ }^{59}$ BUENO, Cassio Scarpinella. Curso sistematizado de direito processual civil: procedimento comum: ordinário e sumário, 2: tomo I., p. 403.
} 


\section{Capítulo II - A desconstituição da coisa soberanamente julgada inconstitucional como hipótese de decisão contra legem}

De fato, como conditio sine qua non à demonstração de sua possibilidade em nosso ordenamento constitucional, é preciso que o fenômeno da desconstituição da coisa soberanamente julgada seja analisado mais detidamente, de modo a se identificar o que, realmente, está a se propor.

Para isso, previamente, é preciso que se firme a necessária premissa de que a ação rescisória, prevista na Constituição Federal e regulada pelo Código de Processo Civil, é o único instrumento processual apto à rescisão da res iudicata, de modo que a incidência do prazo decadencial insculpido no artigo 495 do diploma processual é inevitável.

Será trazida, no presente Capítulo, ainda, a definição doutrinária das chamadas decisões contra legem, buscando-se revelar, em seguida, que, para a desconstituição da chamada coisa soberanamente julgada inconstitucional, necessário é que o Poder Judiciário profira uma decisão de tal natureza.

Ao final, restará concluído que a denominada "flexibilização da coisa (soberanamente) julgada inconstitucional" nada mais é do que uma hipótese de decisão contrária à lei, nos exatos termos em que a doutrina a define. É o que se pretende analisar em seguida.

\section{II.1. O conceito de decisão judicial contra legem}

Inicialmente, para que as características fundamentais das decisões contra legem sejam devidamente traçadas, importante que, de maneira sintética, diferencie-se o conceito de norma e de enunciado normativo, bem como que se relembre a já exposta distinção entre princípios e regras. 
Nesse passo, enunciado normativo corresponde ao conjunto de signos linguísticos que compõem um determinado dispositivo legal ou constitucional. Trata-se, em outras palavras, do texto legal propriamente dito.

Norma, por sua vez, consiste no produto da interpretação de um ou mais enunciados normativos ${ }^{60}$. Corresponde, assim, a um comando específico extraído do texto legal o qual dará solução a um dado caso concreto. "Uma norma", segundo Robert Alexy, "é, portanto, o significado de um enunciado normativo"61.

Para melhor esclarecer a distinção aqui exposta, cumpre mencionar que uma mesma norma pode ser expressa por meio de diferentes enunciados normativos.

Em exemplo trazido pelo referido autor, dispõe o artigo $16, \S 2^{\circ}, 1$, da Constituição alemã que "Nenhum alemão pode ser extraditado.". Desse enunciado normativo, extrai-se a norma segundo a qual é proibida a extradição de um alemão. Tal norma, todavia, pode ser também expressa por outros enunciados normativos, como "É proibido extraditar alemães." ou "Alemães não podem ser extraditados."62.

Da mesma forma, o inverso da referida proposição também é verdadeiro: de um único enunciado normativo diversas normas podem ser retiradas. Como exemplo, tem-se que o artigo $5^{\circ}$, XXXVI, da Constituição Federal dispõe que "a lei não prejudicará o direito adquirido, o ato jurídico perfeito e a coisa julgada.".

De sua interpretação, pode-se extrair uma norma direcionada ao legislador ordinário, segundo a qual lhe é vedado editar lei retroativa que, de alguma forma, prejudique decisões judiciais transitadas em julgado

\footnotetext{
${ }^{60}$ Em sentido diverso, o entendimento de Ana Paula de Barcelos, segundo o qual "para além de outros critérios distintivos, há algum consenso de que princípios e regras são categorias de enunciados que têm estruturas diversas, sendo que essa diferença pode ser descrita de modos variados.". BARCELLOS, Ana Paula de. Ponderação, racionalidade e atividade jurisdicional., p. $168 / 169$.

${ }^{61}$ ALEXY, Robert. Teoria dos Direitos Fundamentais. Tradução de Virgílio Afonso da Silva. $2^{\mathrm{a}}$ ed. São Paulo: Malheiros, 2012, p. 54.

${ }^{62}$ Ibid., 53/54.
} 
anteriores. Conforme demonstrado alhures, porém, partindo do dispositivo constitucional em comento, é possível desenvolver, ao menos, mais uma norma: não deverá o Poder Judiciário, ao aplicar a lei em um dado caso concreto, modificar decisão judicial coberta pelo manto da coisa julgada.

Visto, em linhas gerais, a distinção entre enunciado e norma, recorde-se que as normas (e não os enunciados normativos) podem ser classificadas, segundo sua estrutura, em princípios e regras. Dentre as principais diferenças entre as duas espécies normativas, sabe-se que enquanto os princípios descrevem, até certo ponto ${ }^{63}$, efeitos indeterminados que pretendem produzir no mundo dos fatos, as regras estabelecem, desde logo, as condutas necessárias para sua realização ${ }^{64}$.

As regras, assim, ao prescreverem uma conduta específica, são entendidas como o produto de uma ponderação prévia realizada pelo legislador entre os diferentes princípios e valores incidentes ao caso nela descrito. Impedem, assim, que o intérprete tenha a liberdade de, diante de um conflito normativo, reavalie as razões que lhe deram origem para chegar a uma solução. O desfecho da ponderação normativa já está préestabelecido $^{65}$.

Esse é o motivo pelo qual Ronald Dworkin aduz que as regras são aplicadas na modalidade tudo-ou-nada, i.e., caso os fatos descritos na regra sejam observados no caso concreto, o seu comando deverá ser necessariamente obedecido, a não ser que essa seja considerada inválida ${ }^{66}$.

\footnotetext{
${ }^{63}$ A indeterminação dos efeitos de um princípio é relativa, tendo em vista que, conforme será melhor trabalhado à frente, pode-se sempre ser nele identificado um núcleo de significado, o qual, a propósito, terá natureza de regra. BARCELLOS, Ana Paula de. Ponderação, racionalidade e atividade jurisdicional., p. 178.

${ }^{64}$ Ibid., p. 177/178.

${ }^{65}$ Nesse sentido, Thomas Bustamante: "a lei de colisão implica que toda colisão de princípios só pode ser resolvida pelo estabelecimento de uma regra que estabelece uma relação de prioridade condicionada entre os princípios colidentes. Conversamente, toda regra pode ser apresentada como o resultado de uma ponderação de princípios.". BUSTAMANTE, Thomas da Rosa de. Argumentação contra legem: a teoria do discurso e a justificação jurídica nos casos mais difíceis. Rio de Janeiro: Renovar, 2005, p. 131.

66 "Rules are applicable in an all-or-nothing fashion. If the facts a rule stipulates are given, then either the rule is valid, in which case the answer it supplies must be accepted, or it is not, in which case it contributes nothing to the decision.". DWORKIN, Ronald. Taking rights seriously. Cambridge: Harvard University Press, 1978, p. 24. Conforme se verá mais à frente, o modelo de aplicação das regras proposto por Dworkin deve ser admitido com reservas, tendo em vista a
} 
Essa lógica, contudo, é excepcionada nas chamadas decisões contra legem, na medida em que, nelas, mesmo diante da incidência de uma determinada regra perfeitamente válida em abstrato à hipótese em concreto, decide-se por, casuisticamente, afastá-la. Isso se dá, pois a situação fática criada por sua aplicação ofende de tal forma determinada norma da Constituição Federal que seu afastamento se faz necessário. Estabelece a decisão contra legem, assim, uma exceção não escrita à aplicação da regra $^{67}$.

Assim, conforme aponta Thomas Bustamante em artigo específico sobre o tema ${ }^{68}$, tem-se, como primeiro traço característico das decisões contra legem, que a norma afastada casuisticamente apresenta-se como uma regra. Tal exigência decorre do fato de que os princípios, conforme já se viu, não contém uma hipótese de incidência determinada, de sorte que sua superabilidade, ao contrário das regras, é imanente ${ }^{69}$.

A regra excepcionada pela decisão, ademais, deverá estar veiculada em uma lei, em sentido estrito, ou em um enunciado normativo de igual nível hierárquico. Tal requisito se justifica, tendo em vista que somente se torna realmente problemático se decidir contra o significado mínimo de um enunciado quando esse apresenta uma vinculação geral dentro do sistema jurídico.

Além disso, cumpre notar que a decisão contra legem, ao afastar a aplicação da regra em um determinado caso concreto, não reconhece a sua inconstitucionalidade em abstrato. Diferencia-se, assim, da decisão que, incidentalmente, declara a inconstitucionalidade de uma determinada regra,

possibilidade prática de, ainda que excepcionalmente, se instituir cláusulas de exceção a tal espécie normativa.

${ }^{67}$ BUSTAMANTE, Thomas da Rosa de. Conflitos normativos e decisões contra legem: uma nota sobre a superabilidade das regras jurídicas. In: FELLET, André Luiz Fernandes; DE PAULA, Daniel Giotti; NOVELINO, Marcelo (Org.). As novas faces do ativismo judicial. Salvador: Editora Jus PODIVM, 2011, p. 137.

${ }^{68}$ Ibid., p. 138/141.

69 "Os enunciados que prevêem princípios jurídicos são também superáveis (possuem, inclusive, uma superabilidade imanente, mais intensa que a das regras), haja vista que os fins perseguidos pelos princípios nem sempre são alcançáveis.". BUSTAMANTE, Thomas da Rosa de. Argumentação contra legem: a teoria do discurso e a justificação jurídica nos casos mais difíceis., p. 244. 
pois enquanto esta discute a invalidade geral da norma, aquela a reputa inválida e inaplicável apenas em um caso específico.

Outra fundamental característica desse tipo de decisão é que do enunciado normativo que serve de base para a regra jurídica por ela excepcionada não se pode extrair, por meio da interpretação, norma alternativa que solucione o caso concreto de maneira a se evitar a situação de inconstitucionalidade gerada pela primeira.

Com efeito, muito embora seja normalmente possível extraírem-se, de um mesmo texto legal, diversas normas, as expressões utilizadas pelo legislador apresentam sempre um sentido mínimo; um limite semântico que o intérprete não poderá ultrapassar. Conforme bem esclarece Bustamante, nesse passo, a decisão judicial contra legem justamente argumenta que os significados mínimos de uma regra jurídica não podem ser seguidos em um específico caso concreto, muito embora os fatos que o envolvem sejam, a ela, perfeitamente subsumíveis. Senão vejamos:

\begin{abstract}
"Essa distinção nos será útil porque o que chamamos de argumentação 'contra legem' é, na realidade, a forma de argumentar contrária aos significados mínimos que possui um ou mais texto jurídico cuja validade se mantém fora de dúvida. Em suma, trata-se daquelas espécies de argumentação que buscam comprovar a impossibilidade jurídica de uma decisão fiel aos significados preliminares do enunciado que dá suporte à norma em questão." ${ }^{.70}$
\end{abstract}

Outras particularidades apontadas pelo autor, as quais mais têm a ver com a validade das decisões contra legem do que propriamente com sua estrutura, não serão aqui esmiuçadas, já que, nesse primeiro momento, procura-se apenas classificar as decisões que desconstituem a coisa soberanamente julgada como típicas decisões contra legem, nos exatos termos em que a doutrina as define ${ }^{71}$. A legitimidade para isso será objeto do próximo Capítulo.

\footnotetext{
${ }^{70}$ BUSTAMANTE, Thomas da Rosa de. Argumentação contra legem: a teoria do discurso e a justificação jurídica nos casos mais difíceis., p. 182 - destacou-se.

${ }^{71}$ Aponta o autor, além das características citadas das decisões contra legem, as seguintes: (i) não há dúvidas de que os fatos que deram origem à decisão podem ser subsumidos na regra jurídica excepcionada; (ii) a autoridade que adota essa decisão estabelece uma norma individual formulada em termos universais; e (iii) a decisão levanta uma pretensão de juridicidade para essa norma
} 


\section{II.2. A ação rescisória como o único meio processual apto a rescindir a coisa julgada}

Como já se disse, sustenta-se aqui que para que se "relativize" a coisa (soberanamente) julgada inconstitucional, necessário é o afastamento casuístico da aplicação da regra insculpida no artigo 495 do Código de Processo Civil, nas hipóteses em que a decisão transitada em julgado fere a Constituição da República de maneira excepcionalmente grave.

Nesse sentido, caso fosse possível se desconstituir a coisa julgada por outros instrumentos processuais, que não a ação rescisória, sem que o prazo de dois anos do trânsito em julgado da decisão, previsto no aludido dispositivo legal, tivesse de ser obedecido, a criação de exceções não escritas à regra contida no referido enunciado normativo não seria necessária para o atingimento de tal fim.

Por esse motivo, antes que se passe à análise das características essenciais das decisões que rescindem a coisa soberanamente julgada que a identificam com aquelas descritas pela doutrina como de natureza contra legem, imprescindível que se demonstre que a ação rescisória é o único instrumento processual cabível para a desconstituição da res iudicata.

Pois bem. A intangibilidade da coisa julgada, conforme já exposto, consiste em direito fundamental previsto na Carta Magna em seu artigo $5^{\circ}$, XXXVI. Assim, recorde-se que muito embora se reconheça sua central importância para a segurança e estabilidade de nosso sistema jurídico, certo é que, como todo e qualquer direito, não pode ser considerado absoluto, devendo-se admitir a possibilidade de sua restrição.

Sobre o tema, Robert Alexy, em sua influente Teoria dos Direitos Fundamentais, classifica as restrições aos direitos fundamentais em direta e indiretamente constitucionais ${ }^{72}$.

individual. BUSTAMANTE, Thomas da Rosa de. Conflitos normativos e decisões contra legem: uma nota sobre a superabilidade das regras jurídicas., p. 139.

${ }^{72}$ ALEXY, Robert. Teoria dos Direitos Fundamentais., p. 285/295. 
As restrições diretamente constitucionais, conforme ensina o autor, são aquelas em que a Constituição expressamente estabelece limites a um direito fundamental por ela previsto. Como clássico exemplo, tem-se que a liberdade de reunião, entre nós, é condicionada à ausência de armas e a não frustração de outra reunião anteriormente convocada para o mesmo local (art. 5, XVI, da Constituição brasileira).

As restrições indiretamente constitucionais, por outro lado, se configuram nas hipóteses em que a Constituição autoriza, explícita ou implicitamente, que o legislador ordinário estabeleça determinados limites aos direitos fundamentais. Esse é o caso do direito à liberdade de profissão, que, conforme estipula nosso texto constitucional, poderá ser condicionado às qualificações necessárias para seu exercício, a serem definidas em lei (art. $\left.5^{\circ}, \mathrm{XIII}\right)$.

Nesse contexto, no que tange à imodificabilidade da coisa julgada, note-se que a Constituição estabeleceu uma restrição indireta a tal direito, na medida em que deixou ao encargo do legislador ordinário não só traçar os contornos do instituto da res iudicata, como também preordenar "regras para sua rescisão mediante atividade jurisdicional",73.

Por outro lado, não determinou, de maneira expressa, uma restrição direta ao conteúdo do direito à intangibilidade do caso julgado, também transferindo ao legislador ordinário a competência de prever as hipóteses nas quais poderá ser rescindida a sentença judicial transitada em julgado. Estão elas, a propósito, dispostas taxativamente ao longo dos nove incisos do artigo 485 do Código de Processo Civil $^{74}$.

\footnotetext{
${ }^{73}$ SILVA, José Afonso da. Curso de Direito Constitucional Positivo., p. 436/437.

74 “Art. 485. A sentença de mérito, transitada em julgado, pode ser rescindida quando: I - se verificar que foi dada por prevaricação, concussão ou corrupção do juiz; II - proferida por juiz impedido ou absolutamente incompetente; III - resultar de dolo da parte vencedora em detrimento da parte vencida, ou de colusão entre as partes, a fim de fraudar a lei; IV - ofender a coisa julgada; V - violar literal disposição de lei; VI - se fundar em prova, cuja falsidade tenha sido apurada em processo criminal ou seja provada na própria ação rescisória; VII - depois da sentença, o autor obtiver documento novo, cuja existência ignorava, ou de que não pôde fazer uso, capaz, por si só, de Ihe assegurar pronunciamento favorável; VIII - houver fundamento para invalidar confissão, desistência ou transação, em que se baseou a sentença; IX - fundada em erro de fato, resultante de atos ou de documentos da causa."
} 
Assim, não obstante a ausência de restrição expressa no que tange ao conteúdo do direito fundamental em comento, observe-se que a Constituição Federal determinou, previamente, a forma pela qual essa restrição deverá ser feita ${ }^{75}$, dispondo em seus artigos $102, \mathrm{I}, j ; 105$, I, e ; e 108, I, $b$, a competência dos tribunais para a rescisão de seus respectivos julgados por meio da ação rescisória.

Parece claro, nesse sentido, que a Constituição, por meio dos referidos enunciados normativos, estabeleceu um instrumento processual e um regime de competência próprios para a rescisão das sentenças transitadas em julgado, sendo certo que o direito fundamental à intangibilidade da coisa julgada não pode ser restringido sem sua fiel observância, sob pena de violação ao princípio do devido processo legal em sua acepção adjetiva.

Acercada necessidade da estrita observância ao procedural due process of law nos casos de restrições a direitos constitucionalmente previstos, cite-se a lição do Exmo. Ministro Celso de Mello que, no julgamento da Ação Cautelar no 2.893/PI, assim se pronunciou:

"Cabe advertir, por relevante, considerada a essencialidade da garantia constitucional da plenitude de defesa e do contraditório, que a Constituição da República estabelece, em seu art. $5^{\circ}$, incisos LIV e LV, que ninguém pode ser privado de sua liberdade, de seus bens ou de seus direitos sem o devido processo legal, notadamente naqueles casos em que se viabilize a possibilidade de imposicãa,o, a determinada pessoa ou entidade, de medidas consubstanciadoras de limitação de direitos. ${ }^{\text {Th }}$

\footnotetext{
75 Nesse sentido, no que tange às restrições formais a direitos fundamentais dispostas na Constituição, ensina Robert Alexy que "às disposições de direitos fundamentais não são atribuíveis apenas posições materiais, mas também formais. Essa distinção corresponde à distinção proposta por Shwabe entre um aspecto material e um aspecto modal da proteção dos direitos fundamentais. $O$ aspecto modal diz respeito 'à forma de afetação do bem protegido'. Por 'forma' Shwabe entende as condições formais da atuação dos três Poderes no âmbito dos direitos fundamentais. Dessas condicões fazem parte, dentre outros, o respeito à ordenacão constitucional de competências, a autorização por meio de uma norma suficientemente determinada e o cumprimento de preceitos procedimentais.". ALEXY, Robert. Teoria dos Direitos Fundamentais., p. 290/291 - grifou-se.

${ }^{76}$ STF, Tribunal Pleno, AC no 2893 MC/PI, Rel. Min. Celso de Mello, Brasília, julgamento de 22.06.2011 - grifou-se.
} 
A Constituição, portanto, não deixou qualquer margem ao legislador ordinário ou ao intérprete para que estabeleçam outras formas de desconstituição da coisa julgada, devendo essa, quando for o caso, ser feita por meio de ação rescisória, a ser julgada pelo Tribunal ao qual coube proferir a decisão judicial rescindenda ${ }^{77}$.

Nesse mesmo sentido, interessante observar a opinião de Marcelo Cunha de Araújo, quando ressalta que a necessidade de utilização da ação rescisória para se desconstituir a coisa julgada cível decorre, além da expressa previsão deste instrumento processual pela Constituição, do respeito ao intérprete autorizado, entendido como o órgão apontado pela Lei Fundamental como competente para rescindir a decisão transitada em julgado:

\footnotetext{
"Dessa forma, fica evidente que a desconstituição da coisa julgada inconstitucional só pode se dar por nova manifestação do mesmo Poder Judiciário que a constituiu e na forma prevista pela Constituição. Essa forma prevista na Constituição é o único meio de, a um só tempo, preservar uma das garantias mais importantes e fundamentais de funcionamento do sistema como um todo e individuais do cidadão: a coisa julgada.

(...). Logo, como não se trata de garantia absoluta, a mesma Carta Magna que a previu, expôs seu procedimento de desconstituição: a ação rescisória e a revisão criminal, explicitando o intérprete autorizado a proferir uma segunda manifestação do mesmo Poder, ainda que já tivesse se manifestado de forma definitiva como meio de abrandamento da rigidez gerada pela característica (necessária) da seguranca jurídica da coisa julgada.

Logo, chega-se à primeira conclusão da presente teoria: o único meio de verificação e desconstituição da coisa julgada inconstitucional é a ação rescisória que deverá ser proposta no juízo adequado constitucionalmente. (...)

(...)

Qualquer forma procedimental, que não a ação rescisória prevista constitucionalmente, acabará por ofender a garantia fundamental da coisa julgada e, dessa forma, o intérprete autorizado do direito, não justificando uma segunda decisão em detrimento da primeira.."
}

\footnotetext{
${ }^{77}$ Em sentido contrário, a tese de Carlos Henrique Soares, para quem sentença inconstitucional é sentença inexistente: "Processos ilegítimos e inconstitucionais que levam à formação de uma 'sentença inconstitucional' nada mais são do que sentenças inexistentes, que não podem autorizar a formação da coisa julgada pelo simples fato de que não transitam em julgado. E, não ocorrendo a coisa julgada, não há que se falar em ação rescisória. O que não existe não pode ser rescindido." SOARES, Carlos Henrique. Coisa julgada constitucional., p. 250. Para o autor, então, o único meio processual apto para a rescisão da coisa julgada inconstitucional seria a querela nullitatis, entendida como uma ação declaratória de inexistência. Nesse ponto, reporta-se o leitor à crítica formulada no item "I.5." do primeiro Capítulo acerca da confusão entre os planos da existência, validade e eficácia do ato jurídico.

78 ARAÚJO, Marcelo Cunha de. Coisa Julgada Inconstitucional: Hipóteses de Flexibilização e Procedimentos para Impugnação. Editora Lumen Juris: 2007, p. 202/203 - grifou-se.
} 
Dessa maneira, como bem apontado pelo autor, a inconstitucionalidade da utilização de meios alternativos de rescisão da coisa julgada decorre não só da previsão da ação rescisória como o instrumento processual apto à restrição de tal direito, como também, e principalmente, do regime de competência disposto na Constituição para seu julgamento.

Dos dispositivos constitucionais que tratam da ação rescisória podese extrair uma regra geral de competência, a qual, por sua própria natureza normativa, não deve ser desconsiderada pelo legislador ordinário ou pelo intérprete da Constituição, segundo a qual "os tribunais julgam as ações rescisórias de seus próprios julgados.",79.

O que dizer, então, dos artigos $475-\mathrm{L}, \$^{\circ}$, e 741 , $\S$ único do $\mathrm{CPC}^{80}$, os quais permitem, em sede de impugnação ao cumprimento de sentença ou de embargos à execução opostos pela Fazenda Pública, a rescisão da decisão judicial transitada em julgado nas hipóteses em que tenha ela se fundado em lei declarada inconstitucional pelo Supremo ou em interpretação tida por este como incompatível com a Constituição?

Como se sabe, o juízo da execução e, por consequência, perante o qual serão opostos os embargos ou oferecida a impugnação, é o juízo de primeira instância, sendo certo que, normalmente, não é o mesmo que proferiu a decisão que deu origem ao título executivo judicial. Como permitir, desse modo, diante de tudo o que foi exposto, que a coisa julgada seja rescindida por tais meios?

\footnotetext{
${ }^{79}$ DIDIER JR., Fredie; CUNHA, Leonardo José Carneiro. Curso de Direito Processual Civil, volume 3. $8^{\mathrm{a}}$ ed. Salvador: Editora JusPODIVM, 2010, p. 372.

80 “Art. 475-L (...) § 1o Para efeito do disposto no inciso II do caput deste artigo, considera-se também inexigível o título judicial fundado em lei ou ato normativo declarados inconstitucionais pelo Supremo Tribunal Federal, ou fundado em aplicação ou interpretação da lei ou ato normativo tidas pelo Supremo Tribunal Federal como incompatíveis com a Constituição Federal."

“Art. 741. (...) Parágrafo único. Para efeito do disposto no inciso II do caput deste artigo, considera-se também inexigível o título judicial fundado em lei ou ato normativo declarados inconstitucionais pelo Supremo Tribunal Federal, ou fundado em aplicação ou interpretação da lei ou ato normativo tidas pelo Supremo Tribunal Federal como incompatíveis com a Constituição Federal."
} 
Sobre a questão acima disposta, Fredie Didier Jr., ao comentar o $\S^{\circ}$ do artigo 475-L do CPC, chamou atenção à notória ofensa a um dos principais corolários do princípio do devido processo legal em caso de aplicação do aludido dispositivo, qual seja o direito ao juiz natural:

\begin{abstract}
"Exatamente no que diz respeito à competência é que aparece uma forte objeção à constitucionalidade dessa inovação. É que se se trata realmente de uma nova hipótese de rescisão da coisa julgada, como permitir que o juízo da execução, que normalmente é o juízo de primeira instância, aquele que não proferiu o acórdão executado, possa rescindir um acórdão do tribunal? Se fosse proposta uma rescisória contra o acórdão, com base no inciso $V$ do art. 485 , seria o tribunal que proferiu a decisão rescindenda o competente para rescindi-la. Por que, nesse caso, quem a rescindiria seria o juízo de primeira instância? o direito ao juiz natural deve ser observado, embora esse aspecto tenha passado ao largo das discussões sobre a aplicação do $\$ 1^{\circ}$ do art. 475-L." ${ }^{, 81}$
\end{abstract}

Parece certo, portanto, que, ao autorizarem a desconstituição da coisa julgada por instrumentos processuais alternativos à ação rescisória e por órgãos judiciais distintos daqueles que proferiram a decisão judicial rescindenda, deve-se considerar inconstitucionais os aludidos enunciados normativos $^{82}$.

Ademais, pelos mesmos motivos, e até com maior razão, dada a ausência de previsão legislativa, não se pode admitir a desconstituição da coisa julgada por meios atípicos, por vezes admitidos pela doutrina e pela jurisprudência, como a querela nullitatis, a exceção de pré-executividade, o ajuizamento de nova ação com o mesmo objeto em primeira instância, entre outros.

Nesse sentido, em razão do condão persuasivo que os precedentes das Cortes Superiores exercem sobre os demais Tribunais do país, é com

\footnotetext{
${ }^{81}$ DIDIER JR., Fredie et. al. Curso de Direito Processual Civil, volume 5. $2^{\mathrm{a}}$ ed. Salvador: Editora JusPODIVM, 2010, p. 375

${ }_{82} \mathrm{O}$ artigo 741 , § único do CPC já foi declarado (ao menos parcialmente) inconstitucional em sede de controle difuso pelo Supremo Tribunal Federal, conforme se verifica do seguinte precedente: STF, RE 594350/RS, Rel. Min. Celso de Mello, Brasília, julgamento de 25.05.2010. Acrescente-se aqui que, muito embora se concorde com as razões expostas pelo Ministro Celso de Mello para se declarar a inconstitucionalidade de tal enunciado normativo, tal decisão não poderia ser tomada de forma monocrática, sem a observância da cláusula de reserva de plenário (art. 97 da Constituição). Impende mencionar, ainda, que o Supremo Tribunal Federal ainda não se manifestou nos autos das ADI's n ${ }^{\circ}$ 2.418/DF e 3.740/DF, ajuizadas pelo Conselho Federal da Ordem dos Advogados do Brasil impugnando a constitucionalidade dos artigos 475-L e 741, § único do Código de Processo Civil.
} 
bastante preocupação que se observam alguns julgados proferidos pelo C. STF e pelo E. STJ aceitando, como meio processual legítimo para a desconstituição da coisa julgada, o ajuizamento de ação idêntica àquela cuja decisão transitada em julgado pretende-se rescindir.

Confira-se, a título ilustrativo, acórdão recentemente proferido pelo C. Supremo Tribunal Federal, no qual, em evidente violação ao procedimento previsto na Constituição para a rescisão das decisões transitadas em julgado, admitiu-se que nova ação de investigação de paternidade fosse ajuizada para a produção de exame de DNA, não obstante a existência de coisa julgada anterior ${ }^{83}$ :

"RECURSO EXTRAORDINÁRIO. DIREITO PROCESSUAL CIVIL E CONSTITUCIONAL. REPERCUSSÃO GERAL RECONHECIDA. AC Ã̃̃ DE INVESTIGAĈ̃O DE PATERNIDADE DECLARADA EXTINTA, COM FUNDAMENTO EM COISA JULGADA, EM RAZÃO DA EXISTÊNCIA DE ANTERIOR DEMANDA EM QUE NÃO FOI POSSÍVEL A

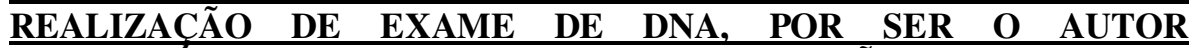
BENEFICÁRIO DA JUSTIÇA GRATUITA E POR NÃO TER O ESTADO PROVIDENCIADO A SUA REALIZAC ÃO. REPROPOSITURA DA ACÃO. POSSIBILIDADE, EM RESPEITO $\grave{A}$ PREVALÊNCIA DO DIREITO FUNDAMENTAL Å BUSCA DA IDENTIDADE GENÉTICA DO SER, COMO EMANACÃ̃O DE SEU DIREITO DE PERSONALIDADE. 1. É dotada de repercussão geral a matéria atinente à possibilidade da repropositura de ação de investigação de paternidade, quando anterior demanda idêntica, entre as mesmas partes, foi julgada improcedente, por falta de provas, em razão da parte interessada não dispor de condições econômicas para realizar o exame de DNA e o Estado não ter custeado a produção dessa prova. 2. Deve ser relativizada a coisa julgada estabelecida em ações de investigacão de paternidade em que não foi possível determinar-se a efetiva existência de vínculo genético a unir as partes, em decorrência da não realizacão do exame de DNA, meio de prova que pode fornecer seguranca quase absoluta quanto à existência de tal vínculo. 3 . Não devem ser impostos óbices de natureza processual ao exercício do direito fundamental à busca da identidade genética, como natural emanação do direito de personalidade de um ser, de forma a tornarse igualmente efetivo o direito à igualdade entre os filhos, inclusive de qualificações, bem assim o princípio da paternidade responsável. 4. Hipótese em que não há disputa de paternidade de cunho biológico, em confronto com outra, de cunho afetivo. Busca-se o reconhecimento de paternidade com relação a pessoa identificada. 5. Recursos extraordinários conhecidos e providos." ${ }^{~} 84$

\footnotetext{
${ }^{83}$ Exponha-se que, conforme se afere de trecho do voto-vista do Exmo. Min. Luiz Fux, a coisa soberanamente julgada já havia se formado: "In casu, operou-se o trânsito em julgado da demanda anterior em 1992, ao passo que o processo ora em exame foi instaurado apenas em 21 de outubro de 1996.”.

${ }^{84}$ STF, Tribunal Pleno, RE 363.889/DF, Rel. Min. Dias Toffoli, Brasília, julgamento de 02.06.2011 - grifou-se. Da mesma forma já havia anteriormente se pronunciado o E. STJ,
} 
Diante de todo o exposto, em conclusão essencial à classificação das decisões que rescindem a coisa soberanamente julgada como hipóteses de decisões contrárias à lei, pode-se dizer que a ação rescisória é o único instrumento processual apto a se desconstituir uma decisão transitada em julgado, sendo inevitável, para isso, a observância do prazo decadencial de dois anos estipulado no artigo 495 do CPC para o seu ajuizamento.

\section{II.3. A natureza jurídica da norma disposta no artigo 495 do CPC e seu núcleo de sentido}

Firmada a premissa de que o artigo 495 do CPC vincula todas as decisões que desconstituem a coisa julgada, de modo a limitá-las ao prazo temporal de dois anos do trânsito em julgado da decisão judicial rescindenda, passa-se, aqui, à investigação da natureza da norma contida em tal enunciado normativo, bem como do núcleo de significado de seu texto.

Tal análise será essencial para o fim de se identificar as decisões que desconsideram o prazo de dois anos para a desconstituição da res iudicata com as chamadas decisões contrárias à lei, as quais, conforme visto, superam uma determinada regra jurídica cujas condições para aplicação estão satisfeitas no caso concreto, afastando-a casuisticamente.

Com efeito, como já se disse, sabe-se que os textos legais, dos quais decorrem as normas jurídicas, possuem limites semânticos que não podem ser ultrapassados. As expressões linguísticas utilizadas pelo legislador, em outros termos, guardam um núcleo de significados possíveis, que deverá sempre servir de ponto de partida para a interpretação jurídica e à utilização das técnicas gerais de hermenêutica, mas que são intangíveis pelo intérprete. Sobre o tema, registre-se o insuperável ensinamento de Humberto Ávila:

conforme se afere do seguinte precedente: STJ, $4^{\text {a }}$ Turma, REsp 226.436/PR, Rel. Min. Sálvio de Figueiredo Teixeira, Brasília, julgamento de 28.06.2001. 
"Todavia, a constatação de que os sentidos são construídos pelo intérprete no processo de interpretação não deve levar à conclusão de que não há significado algum antes do término desse processo de interpretação. Afirmar que o significado depende do uso não é o mesmo que sustentar que ele só surja com o uso específico e individual. Isso porque há traços de significado mínimos incorporados ao uso ordinário ou técnico da linguagem. (...)

Por conseguinte, pode-se afirmar que o intérprete não só constrói, mas reconstrói sentido, tendo em vista a existência de significados incorporados ao uso lingüístico e construídos na comunidade do discurso. Expressões como "provisória" ou "ampla", ainda que possuam significações indeterminadas, possuem núcleos de sentidos que permitem, ao menos, indicar quais as situações em que certamente não se aplicam: provisória não será aquela medida que produz efeitos ininterruptos no tempo; ampla não será aquela defesa que não dispõe de todos os instrumentos indispensáveis à sua mínima realização. E assim por diante. Daí se dizer que interpretar é construir a partir de algo, por isso significa reconstruir: a uma, porque utiliza como ponto de partida os textos normativos, que oferecem limites à construção de sentidos; a duas, porque manipula a linguagem, à qual são incorporados núcleos de sentidos, que são, por assim dizer, constituídos pelo uso, e preexistem ao processo interpretativo individual., ${ }^{\$ 5}$

Nesse sentido, diante da já trazida distinção entre as duas espécies normativas, pode-se afirmar, sem qualquer receio, que o espaço para interpretações deixado pelos textos legais que dão origem às regras é, por definição, menor do que aquele deixado pelos dispositivos dos quais decorrem os princípios, sendo o primeiro, por vezes, quase inexistente.

Como à frente se demonstrará, é esse, justamente, o caso do artigo 495 do CPC, cujo teor encontra-se abaixo transcrito:

"Art. 495. O direito de propor ação rescisória se extingue em 2 (dois) anos, contados do trânsito em julgado da decisão."

Assim, em primeira ordem, não há duvidas de que a norma, a qual de forma mais evidente se constata do dispositivo legal em comento, tem natureza de regra, já que estabelece, de forma concreta, o efeito que pretende produzir no mundo dos fatos: impedir que, após o prazo de dois anos do trânsito em julgado da decisão, seja ela desconstituída.

Outro traço desta norma insculpida no artigo 495 do CPC que a caracteriza como uma regra jurídica é o de que os princípios que a fundamentam e que pretende ela realizar, como o da segurança jurídica e da

${ }^{85}$ ÁVILA, Humberto. Teoria dos Princípios - da definição à aplicação dos princípios jurídicos. $13^{\mathrm{a}}$ ed. São Paulo: Malheiros, 2012, p. 35/37. 
intangibilidade da res iudicata, não são por ela explicitados, estando escondidos por de trás de seu comando.

É de se reconhecer, desse modo, que há pouquíssimo espaço, para não se dizer nenhum, para interpretações do enunciado normativo em questão e criação de novas normas a partir dele, sobretudo em virtude da ausência de termos jurídicos indeterminados ao longo de seu texto. A regra, aqui disposta, é clara: transitada em julgado a decisão judicial, somente será possível sua rescisão por meio de ação rescisória proposta dentro do prazo máximo de dois anos.

A despeito de tal constatação, entretanto, alguns juristas têm proposto uma solução alternativa para o problema da eventual inconstitucionalidade da coisa soberanamente julgada, qual seja interpretar o artigo 495 do CPC de forma "extensiva", de modo que, em certos casos, fosse reconhecido que o início do prazo para o ajuizamento da ação rescisória não teria início no trânsito em julgado da sentença, mas sim em um momento posterior.

Nesse sentido, por exemplo, é como se posiciona o processualista Cassio Scarpinella Bueno:

\begin{abstract}
"Uma das formas de se obter este resultado sem necessidade de alteração legislativa é admitir uma leitura ampliativa, extensiva, até mesmo criativa, dos diversos incisos do art. 485, flexibilizando-se, com isto, os casos de cabimento da 'ação rescisória'. Quando menos, em alguns casos, sendo necessária uma fluência diferenciada do prazo decadencial para ajuizamento da 'ação rescisória' sem os rigores do art. 495, que não distingue as variadas hipóteses pelas quais, de acordo com o próprio art. 485, a rescisória tem cabimento. Assim, por exemplo, para em determinadas situações o prazo para o exercício daquela demanda tenha início não do transito em julgado da decisão que se pretende questionar, mas, diferentemente, da descoberta, objetivamente constatável, do fato que dá origem ao contraste do que foi julgado e que está imunizado pela coisa julgada." ${ }^{86}$
\end{abstract}

Concessa venia, não obstante a eventual inconveniência causada pela ausência de previsão legislativa de hipóteses especiais de fluência do prazo decadencial de dois anos para ajuizamento da ação rescisória, parece certo

${ }^{86}$ BUENO, Cassio Scarpinella. Curso sistematizado de direito processual civil: procedimento comum: ordinário e sumário, 2: tomo I., p. 403/404. 
que a "criativa" interpretação proposta pelo autor foge totalmente do significado mínimo do texto legal em tela.

É evidente que diante da menção legal de que o prazo decadencial para o ajuizamento da ação rescisória é de dois anos "contados do trânsito em julgado da decisão", espaço não há para que o intérprete modifique, para onde bem entender, o seu termo inicial. Haveria aqui, nesse caso, uma violação ao núcleo de significado do texto normativo.

Por certo, conforme corrobora Walter de Agra Jr., a modificação do termo a quo de fluência do prazo decadencial para propositura da rescisória depende, invariavelmente, de uma previsão legislativa nesse sentido ou da alteração do dispositivo legal ora comentado:

"Não se pode deixar de lado o pressuposto de que a ação rescisória só pode ser utilizada até 02 (dois) anos após o trânsito em julgado por força de limitação legal. É bem verdade que seria muito conveniente e adequado a majoração desse prazo para os casos de coisa julgada inconstitucional ou, até mesmo, a ausência de limitação temporal para esse caso. Todavia, mister se faz uma modificação normativa. Da forma como hoje se apresenta, não vejo como suplantar este obstáculo decadencial. ${ }^{87,}$

Resta constatado, dessa maneira, que, nas decisões que rescindem a coisa soberanamente julgada, não é possível a estruturação de uma norma jurídica alternativa, a partir da interpretação do artigo 495 do CPC, que não as viole, de modo que, nesses casos, sempre se fará necessário que se contrarie o sentido mínimo do aludido dispositivo legal.

\section{II.4. A indiscutível constitucionalidade em tese da norma derivada do artigo 495 do CPC}

Outra fundamental característica das decisões contrárias à lei é que, nelas, não se reconhece que a regra jurídica cuja aplicação é afastada no caso concreto é inconstitucional em abstrato. A incidência da norma, ao

\footnotetext{
${ }^{87}$ AGRA JÚNIOR, Walter de. Flexibilização da Coisa Julgada Inconstitucional. Disponível em $<$ http://www.unicap.br/tede/tde_arquivos/4/TDE-2008-05-17T094458Z159/Publico/walter_dissert.pdf. Acesso em 09.09.2012>-destacou-se.
} 
contrário, é tida por inválida somente naquela determinada hipótese submetida a julgamento, muito embora sua validade geral não seja discutida na decisão.

Com efeito, somente se terá uma decisão genuinamente contra legem quando o julgador deixar de aplicar uma regra válida em abstrato e que seria pertinente no caso concreto $^{88}$, sob a justificativa de que a situação fática decorrente de sua aplicação fere de tal maneira a Constituição Federal que imprescindível é seu afastamento no caso concreto.

Verdade é, nesse contexto, que, conforme bem ressalta Thomas Bustamante, "uma decisão deixa de ser contra legem para se transformar em uma declaração de inconstitucionalidade quando passa a discutir a validade geral da norma afastada" ${ }^{\text {" } 9}$.

Não é esse o caso das decisões que desconstituem a coisa soberanamente julgada, uma vez que a regra por elas afastada, a qual deriva do artigo 495 do CPC, é plenamente constitucional e válida, conforme se passa aqui a demonstrar.

Como já se mencionou anteriormente, a mitigação ao direito fundamental à intangibilidade da coisa julgada deriva da própria Constituição Federal, a qual, apesar de não discorrer acerca das hipóteses em que a res iudicata pode ser desconstituída, o que foi deixado a cargo do legislador infraconstitucional, admite que isso seja feito por meio da ação rescisória, desde que respeitado o regime de competência nela disposto.

É certo, entretanto, que o princípio da imodificabilidade do caso julgado, assim como o da segurança jurídica, do qual é corolário, restariam completamente esvaziados acaso não houvesse qualquer limite temporal para a desconstituição das decisões judiciais transitadas em julgado pela parte inconformada.

A possibilidade eterna de se desconstituir a coisa julgada é contraditória com a própria função que a Constituição reservou a tal

\footnotetext{
${ }^{88}$ BARCELLOS, Ana Paula de. Ponderação, racionalidade e atividade jurisdicional., p. 204.

${ }^{89}$ BUSTAMANTE, Thomas da Rosa de. Conflitos normativos e decisões contra legem: uma nota sobre a superabilidade das regras jurídicas., p. 140.
} 
instituto por meio de seu artigo $5^{\circ}$, XXXVI, qual seja a de garantir, preenchidos determinados pressupostos, a definitividade daquilo que foi decidido. Obviamente, de nada adiantaria a estabilização da decisão judicial pela coisa julgada se a última pudesse ser eternamente rescindida por um pronunciamento posterior do Judiciário.

Além disso, conforme lição tão repetida pela doutrina tradicional quanto verdadeira, a ausência de um limite temporal para a possibilidade de rescisão da coisa julgada levaria, invariavelmente, à eternização dos conflitos submetidos ao Judiciário, o que se apresenta como um mal maior do que a eventual eternização de um erro judiciário na esfera cível:

\begin{abstract}
"A segurança das relações sociais exige que a autoridade da coisa julgada, uma vez estabelecida, não fique demoradamente sujeita à possibilidade de remoção. Ainda quanto às sentenças eivadas de vícios muito graves, a subsistência indefinida da impugnabilidade, incompatível com a necessidade de certeza jurídica, não constituiria solução aceitável no plano da política legislativa, por mais que em seu favor se pretendesse argumentar com o mal que decerto representa a eventualidade de um prevalecimento definitivo do erro." 90
\end{abstract}

Não há como negar que a perenidade da ação rescisória teria como inafastável efeito colateral o prolongamento indefinido dos conflitos, o que, por consequência, acabaria com a certeza jurídica das decisões judiciais, necessária ao Estado Democrático de Direito.

Com efeito, sabe-se que o direito submetido ao litígio é sempre incerto, não havendo, em um processo judicial, qualquer garantia que o magistrado solucionará o caso dessa ou daquela forma. "O processo", em precisa lição de Fredie Didier Jr. que merece ser aqui reproduzida, "garante-nos a certeza dos meios e a incerteza dos resultados" $"$.

Por esse motivo, permitir que qualquer decisão transitada em julgado fosse indefinidamente passível de desconstituição por pronunciamento posterior do Judiciário seria o mesmo que submeter o direito do indivíduo,

\footnotetext{
${ }^{90}$ MOREIRA, José Carlos Barbosa. Comentários ao Código de Processo Civil, Lei no 5.869 , de 11 de janeiro de 1973, vol. V: arts. 476 a 565., p. 217.

${ }^{91}$ DIDIER JR., Fredie et. al. Curso de Direito Processual Civil, volume 2., p. 446.
} 
já reconhecido judicialmente, à eterna incerteza que caracteriza o contencioso judicial:

\begin{abstract}
"Não há como saber qual será o resultado de um processo, embora possamos prever toda uma sequência de atos processuais que devem ser praticados. $\mathrm{O}$ direito tido como certo pelo demandante, no processo é mera expectativa.

(...). E uma vez instaurado o processo, o resultado é incerto: pode o demandante ganhar ou perder. Ignora-se esse fato. $\mathrm{O}$ resultado do processo não se sabe antes do processo; a solução é, como se disse, construída. É por isso que a acão rescisória (instituto que é a síntese de vários meios de impugnação das sentenças desenvolvidos em anos de história da civilização contemporânea) é típica e tem um prazo para ser ajuizada.'
\end{abstract}

Assim é que o limite temporal para a rescisão das decisões transitadas em julgado, estabelecido pelo artigo 495 do CPC, não só é plenamente constitucional, como também imprescindível à realização dos princípios constitucionais da imutabilidade do caso julgado e da segurança jurídica.

Nesse passo, pode-se até argumentar, como o fazem alguns juristas, que a fixação de um mesmo dies a quo para a fluência do prazo de ajuizamento da ação rescisória para todas as hipóteses de rescisão da coisa julgada seria inapropriado, ou mesmo que a previsão de um prazo único para todos os casos não seria oportuno, tendo em vista a gravidade de algumas situações que exigem tratamento diferenciado.

Entretanto, o suposto inconveniente causado pela rigidez da política legislativa, como visto, está longe de configurar a inconstitucionalidade da regra disposta no artigo 495 do CPC. Por esse motivo é que Nelson Nery Jr., apesar de sugerir alterações nos critérios de rescisão da coisa julgada, afirma que elas não prescindem de uma mudança na legislação processual:

\footnotetext{
"Existindo casos específicos identificados pela doutrina, que mereçam tratamento diferenciado no que pertine à coisa julgada - por exemplo, investigação de paternidade secundum eventum probationis -, somente com a modificação da lei, nela incluindo a hipótese de exceção, é que poderão ser abrandados os rigores da coisa julgada." 93
}

\footnotetext{
${ }^{92}$ Ibid., p. $446 / 447$ - grifou-se.

${ }^{93}$ NERY JUNIOR, Nelson. Teoria geral dos recursos., p. 522.
} 
Assim, diante da plena constitucionalidade do artigo 495 do CPC, pode-se mais uma vez concluir que a desconstituição da coisa soberanamente julgada depende, invariavelmente, de uma decisão contrária à lei, a qual estabeleça uma exceção não escrita à regra insculpida no aludido dispositivo legal.

\section{II.5. Conclusão parcial: a indispensabilidade de uma decisão contrária à lei para a desconstituição da coisa soberanamente julgada}

Ao longo do presente Capítulo buscou-se demonstrar que para a rescisão de uma decisão transitada em julgado há mais de dois anos, inevitável é que o Poder Judiciário supere, de maneira casuística, a regra insculpida no artigo 495 do CPC.

Para tanto, trouxeram-se aqui as características essenciais das chamadas decisões contra legem, sem as quais não se pode classificar um provimento jurisdicional desta forma, para que, em seguida, fossem elas identificadas com as peculiaridades próprias que as decisões que rescindem a coisa soberanamente julgada necessitam ter.

Primeiramente, viu-se que a ação rescisória é o único remédio processual apto a rescindir as decisões judiciais transitadas em julgado. Tal conclusão foi de extrema importância para se comprovar a essencialidade da observância, nesses casos, do disposto no artigo 495 do CPC, o qual determina um prazo máximo para seu manejo.

Além disso, observou-se que o texto do referido dispositivo legal possui um núcleo de significado extremamente amplo, o qual impede que o intérprete dele extraia uma norma alternativa que pudesse justificar o ajuizamento da rescisória depois de esgotado o prazo de dois anos contados do trânsito em julgado da decisão rescindenda.

Vê-se, com isso, que a decisão que desconstitui a coisa soberanamente julgada, ao afastar casuisticamente a regra descrita no artigo 
495 do CPC, vai frontalmente de encontro ao sentido mínimo daquilo que está estipulado no dispositivo legal. Como se viu, o Judiciário, nesse caso, cria uma exceção não escrita à aplicação de tal regra jurídica.

Por fim, restou cabalmente demonstrado a plena constitucionalidade do limite temporal para rescisão das decisões transitadas em julgado. A relevância disso - relembre-se - decorre do fato de que, nas hipóteses de decisões contra legem, a norma afastada não é considerada abstratamente inconstitucional pelo órgão julgador, mas sua incidência no caso concreto fere a Constituição de tal maneira que necessário se faz afastar sua aplicação.

É de se concluir, portanto, diante da identificação de uma inafastável argumentação contrária ao sentido mínimo de um enunciado que dá origem a uma regra jurídica, que, para a desconstituição da coisa soberanamente julgada, é necessário ao Judiciário que profira uma decisão contra legem, nos exatos termos em que a doutrina a define.

Por consequência, pode-se afirmar que a enorme polêmica instaurada em nossa doutrina e jurisprudência em torno da possibilidade da chamada relativização da coisa julgada inconstitucional (rectius: coisa soberanamente julgada inconstitucional) remonta a discussão sobre a legitimidade das decisões contra legem.

Admitir que o Poder Judiciário desconstitua a coisa soberanamente julgada, por certo, é o mesmo que acolher a legitimidade de decisões contrárias à lei.

Assim é que o próximo Capítulo mostrará os principiais fundamentos trazidos por nossa doutrina para justificar as decisões judiciais que contrariem o significado mínimo das regras jurídicas, identificando aquele que, mais precisamente, demonstra a viabilidade, ainda que excepcional, da rescisão da coisa julgada mesmo depois de esgotado o prazo de dois anos da decisão que lhe serviu de base. 


\section{Capítulo III - O conflito em concreto entre regras jurídicas e a potencial superabilidade do limite temporal para a desconstituição da coisa julgada}

A viabilidade de se afastar a aplicação de uma regra jurídica, ainda que sua incidência seja incontroversa no caso concreto, apesar de enfrentar preconceitos, tem sido admitida e, com alguma profundidade, estudada por juristas contemporâneos.

Desse modo, o presente Capítulo trará à tona, em um primeiro momento, os motivos da resistência de muitos pensadores em admitir o afastamento casuístico da aplicação das regras jurídicas. Ver-se-á, nessa linha, a razão pela qual essa resistência é ainda mais intensa no caso do afastamento in concreto do limite temporal para a desconstituição da coisa julgada.

Em seguida, serão apresentadas as principais linhas de argumentação que se propõem a justificar a possibilidade, ainda que excepcional, do afastamento casuístico das regras jurídicas válidas e incidentes ao caso concreto.

Por fim, identificar-se-á aquela que possa demonstrar a legitimidade dos atos jurisdicionais que, diante da violação que por parte da decisão rescindenda à Constituição Federal, desconstitui a coisa soberanamente julgada sobre ela formada, afastando a aplicação, in casu, da regra disposta no artigo 495 do CPC.

\section{III.1. A importância da obediência à regra insculpida no artigo 495 do Código de Processo Civil}

Conforme já se viu, as duas espécies normativas existentes podem ser diferenciadas da seguinte forma: enquanto os princípios são comandos de otimização, na medida em que determinam que algo seja realizado na maior medida possível, as regras podem ser entendidas como comandos de 
definiçãa, tendo em vista que possuem determinações concretas sobre o que deve ser feito ${ }^{94}$.

Assim sendo, em razão de tal diferença estrutural entre os dois tipos de normas, sabe-se que princípios e regras exercem papéis singulares em nosso sistema jurídico.

Com efeito, é possível vincular a elaboração de enunciados normativos que veiculam princípios ao intuito do legislador, nas hipóteses abarcadas pela norma, de prestigiar a justiça do caso concreto. Isso se dá em razão da liberdade que os princípios, por definição, conferem ao julgador para adaptar seu sentido geral às infinitas possibilidades da hipótese a ser regulada ${ }^{95}$.

Já as regras jurídicas, por outro lado, têm a função de conferir segurança ao ordenamento. De fato, uma vez que exigem condutas predeterminadas do sujeito de passivo de seus comandos, "as regras contribuem para a maior previsibilidade do sistema jurídico." ${ }^{, 96}$.

Nesse ponto, relembre-se que as regras decorrem, em última análise, da ponderação realizada pelo legislador entre os diversos princípios incidentes na hipótese por ela normatizada, o que, à primeira vista, impede que o intérprete os reavalie nos casos em que a situação fática descrita pela regra for observada:

\footnotetext{
"Quando o legislador estabelece uma regra, esta pode ser apresentada como o resultado de uma escolha (obviamente dentro de uma margem de discricionariedade deixada pela Constituição) acerca da precedência de determinado princípio constitucional na situação que constitui a hipótese de incidência dessa regra.",97
}

\footnotetext{
${ }^{94}$ BARCELLOS, Ana Paula de. Ponderação, racionalidade e atividade jurisdicional., p.181/183.

${ }^{95}$ Nesse sentido, a lição de Ana Paula de Barcellos: "A justiça, por sua vez, depende em geral de disposições mais flexíveis, à maneira dos princípios, que permitam uma adaptação mais livre às infinitas possibilidades do caso concreto e que sejam capazes de conferirão intérprete liberdade de adaptar o sentido geral do efeito pretendido, muitas vezes impreciso e indeterminado, às particularidades da hipótese examinada." Ibid., p. 186.

${ }_{96}^{96}$ Ibid., p. 186.

${ }^{97}$ BUSTAMANTE, Thomas da Rosa de. Conflitos normativos e decisões contra legem: uma nota sobre a superabilidade das regras jurídicas., p. 119.
} 
É por esse motivo que um sistema composto exclusivamente de princípios, ou de regras, seria inviável na prática. No primeiro caso, o intérprete deveria sempre realizar a ponderação entre os diversos princípios colidentes para dar solução ao respectivo caso concreto. Não é preciso descrever a incerteza jurídica que tal quadro geraria na sociedade.

Daí, conforme bem sintetizado pelo prestigiado jurista Humberto Ávila, é que decorre o primeiro motivo para a importância da fiel obediência às regras em geral: “como as regras têm a função de pré-decidir o meio de exercício do poder, elas afastam a incerteza que surgiria não tivesse feito essa escolha." 98.

É certo, ademais, que a ausência das regras jurídicas (ou a sua cotidiana desobediência) favoreceria a arbitrariedade e o subjetivismo dos julgadores. Por certo, a corriqueira aplicação direta dos princípios jurídicos, em razão de sua textura aberta, abriria uma perigosa margem ao julgador para que decidisse conforme convicções ou interesses pessoais.

As regras, ao impor a realização de uma conduta específica, sem se ocupar diretamente com os fins a serem realizados, limitam a discricionariedade do julgador, diminuindo a possibilidade de que esse se utilize da indefinição dos princípios para solucionar o conflito da maneira como melhor o convir:

\footnotetext{
"A observância fiel das regras, ainda que elas possam gerar incidências injustas ocasionais, é um meio de fortalecer o respeito institucional pela ordem jurídica. Parece evidente que a flexibilização corriqueira do disposto pelas regras fragiliza a estrutura do Estado de direito, além de favorecer o exercício de autoridades arbitrárias e voluntaristas." 99
}

Além disso, por predeterminar o resultado do conflito dos princípios incidentes à hipótese, pode-se dizer que as regras jurídicas se apresentam como um fator de igualdade entre os indivíduos. Confia-se que em todos os casos em que a situação fática descrita pela regra for observada, o julgador

\footnotetext{
98 ÁVILA, Humberto. Teoria dos Princípios - da definição à aplicação dos princípios jurídicos., p. 121.

${ }^{99}$ BARCELlOS, Ana Paula de. Ponderação, racionalidade e atividade jurisdicional., p.208.
} 
as solucionará de maneira uniforme, nos termos daquilo que está nela imposto.

Justamente por esse motivo, como será melhor visto à frente, é essencial que as conclusões alcançadas pelas decisões contra legem sejam lançadas em termos universais. Em verdade, ao excepcionar uma determinada regra jurídica, o intérprete cria uma nova regra, a qual dispõe sobre as hipóteses em que a aplicação da primeira será afastada. Para que tenha legitimidade, a regra de exceção deverá sempre ser aplicada nas hipóteses em que a situação fática observada se repetir.

Por fim, não há como negar que se admitir a criação de cláusulas de exceção pelo julgador às regras jurídicas, ainda que de maneira eventual, implica em uma ruptura do sistema de separação de poderes, ao menos em sua concepção clássica, na medida em que o trabalho do legislador está, em última análise, sendo desconsiderado e refeito pelo intérprete.

Já o desrespeito corriqueiro às regras jurídicas por parte do Poder Judiciário, por sua vez, esvaziaria por completo tal importante princípio, alçado pela Constituição Federal ao patamar de cláusula pétrea ${ }^{100}$. Com efeito, de pouco valeriam as decisões tomadas pelo Poder Legislativo ao criar enunciados que veiculam regras jurídicas acaso o Judiciário pudesse, a toda hora, excepcioná-las, refazendo todo o processo legislativo e sopesando, novamente, os princípios constitucionais envolvidos na questão $^{101}$.

É de se concluir, portanto, de acordo com o que foi exposto, que simplesmente por estar protegida por uma regra jurídica, a qual decorre da interpretação do artigo 495 do Código de Processo Civil, a desconstituição da coisa soberanamente julgada deve ser tratada como uma exceção em nosso sistema.

\footnotetext{
${ }^{100}$ Conforme artigo 60, § 4º , III da Constituição Federal: “Art. 60. A Constituição poderá ser emendada mediante proposta: (...) $\S 4^{\circ}$ - Não será objeto de deliberação a proposta de emenda tendente a abolir: (...) III - a separação dos Poderes; (...)”.

${ }^{101}$ BARCELLOS, Ana Paula de. Ponderação, racionalidade e atividade jurisdicional., p.188.
} 
Sobre o tema aqui em questão, mais especificamente ao dissertar acerca das condições materiais para a superabilidade das regras, Ávila ensina que a possibilidade de criação de exceções casuísticas em uma norma deste tipo será tão mais difícil quanto maior for o dano por parte da decisão particularista à finalidade que se encontra a ela subjacente e à promoção da segurança jurídica $^{102}$.

O critério ora exposto, segundo o autor, se justifica pelo fato de que as regras jurídicas são típicos instrumentos de solução previsível, eficiente e equânime dos conflitos, de modo que se sua flexibilidade dependerá do grau de realização no caso concreto de suas funções primordiais na sociedade ${ }^{103}$.

Nesse passo, no que tange à desconstituição da coisa soberanamente julgada, a regra insculpida no artigo 495 do CPC, como já se viu, tem como função tornar a decisão transitada em julgado há mais de dois danos imodificável. É da finalidade da norma que passado tal período de tempo, o efeito substitutivo da coisa julgada, o qual determina que todas as nulidades e anulabilidades porventura existentes sejam substituídas pela sentença ${ }^{104}$, nunca mais seja contestado.

Observa-se, assim, que, ao determinar um prazo máximo para a desconstituição da sentença transitada em julgado, o legislador tinha em mente que eventuais decisões judiciais contrárias à Constituição Federal e, por isso, nulas de pleno direito seriam protegidas por essa regra.

A existência da coisa soberanamente julgada inconstitucional, indubitavelmente, foi prevista pelo legislador e a proteção de sua estabilidade está entre as finalidades da regra, o que eleva em muito o seu grau de resistência à criação de exceções pontuais. Talvez seja esse o principal motivo, aliás, pelo qual a desconstituição da coisa soberanamente

\footnotetext{
102 De acordo com Humberto Ávila, "o grau de resistência de uma regra à superação está vinculado tanto à promoção do valor subjacente à regra (valor substancial específico) quanto à realização do valor formal subjacente às regras (valor formal da segurança jurídica).”. ÁVILA, Humberto. Teoria dos Princípios - da definição à aplicação dos princípios jurídicos., p. 126.

${ }^{103}$ Ibid., p. 123.

${ }^{104}$ NERY JUNIOR, Nelson. Teoria geral dos recursos., p. 503.
} 
julgada se apresente como um tema que origina tantas discussões em nossa doutrina e jurisprudência.

Ademais, evidente é que, como demonstrado em outra oportunidade, a superação da regra aqui comentada tem como inevitável consequência o comprometimento da segurança das relações jurídicas, na medida em que deixa em aberto a eterna possibilidade de se desconstituir uma decisão judicial transitada em julgado.

No caso do artigo 495 do diploma processual, um dos valores promovidos pela regra é a própria segurança jurídica, motivo pelo qual, nos termos do ensinamento do referido autor, sua superação casuística encontra ainda mais dificuldades:

\footnotetext{
"Conjugando esses fatores, pode-se afirmar que a resistência à superação de uma regra será tanto maior quanto mais importante for a segurança jurídica para sua interpretação. (...) a segurança será tanto mais importante quanto maior for a vinculação desse valor sobrejacente com o valor subjacente à regra. Isso surge quando o princípio da segurança jurídica é importante para o setor no qual a regra se insere e a finalidade subjacente à regra está relacionada com a promoção da segurança.

Sendo assim, a resistência à superação será muito pequena naqueles casos em que o alargamento ou a restrição da hipótese da regra em razão da sua finalidade forem indiferentes ao valor da segurança jurídica. E será tanto maior quanto mais a superação comprometer a realização do valor da segurança jurídica."
}

Desse modo, encontra-se uma excepcional resistência à superação pelo intérprete da regra extraída do art. 495 do CPC, o que pode ser justificado, a uma, pela sua própria estrutura normativa; a duas, porque, neste caso, restará prejudicada a finalidade escondida por detrás da norma e; a três, em virtude do inevitável comprometimento da segurança jurídica.

Contudo, a criação de exceções às regras jurídicas em geral e, em específico, à regra que estipula um limite temporal para a rescisão das decisões transitadas em julgado, não pode ser totalmente descartada, tendo

105 ÁVILA, Humberto. Teoria dos Princípios - da definição à aplicação dos princípios jurídicos., p. 126 - grifou-se. Da mesma forma se posiciona Ana Paula de Barcellos que, ao dissertar sobre as hipóteses de superação das regras, afirma que a situação em que se observa a mais grave intervenção no sistema jurídico se dá quando o legislador previu a hipótese sob julgamento, "mas a solução por ele concebida, em determinado caso, torna-se incompatível com a Constituição". BARCELLOS, Ana Paula de. Ponderação, racionalidade e atividade jurisdicional., p.233. 
em vista a existência de situações verdadeiramente excepcionais em que o limite temporal para a rescisão da coisa julgada deverá ceder em benefício de outros valores. É o que se procurará demonstrar nos dois próximos tópicos.

\section{III.2. O Direito como um sistema de normas superáveis ${ }^{106}$}

De fato, um dos principais pontos de divergência entre a teoria dos Direitos Fundamentais de Alexy e a Teoria dos Princípios de Ronald Dworkin consiste na excepcional possibilidade, admitida pelo autor alemão e, aparentemente, negada pelo norte-americano, de se criar cláusulas de exceção às regras jurídicas.

Conforme já se mencionou ${ }^{107}$, entende Dworkin que o modo de aplicação das regras segue a lógica do tudo-ou-nada, i.e., acaso pertinentes ao caso concreto, as regras só poderão deixar de ser aplicadas se consideradas inválidas pelo julgador. $\mathrm{O}$ que caracterizaria as regras, assim, segundo sustenta, seria seu caráter definitivo e absoluto.

Dessa maneira, o modelo de diferenciação entre regras e princípios proposto por Dworkin nega a viabilidade de uma eventual superação de regras jurídicas válidas em abstrato ${ }^{108}$, sobretudo quando afirma que eventuais exceções às regras decorrem, na verdade, de uma análise mais acurada pelo intérprete de seu comando. Por esse motivo, tais exceções,

\footnotetext{
106 A expressão é de autoria de Thomas Bustamante. BUSTAMANTE, Thomas da Rosa de. Argumentação contra legem: a teoria do discurso e a justificação jurídica nos casos mais difíceis., p. 171.

${ }^{107}$ Vide nota de rodapé $\mathrm{n}^{\circ} 66$.

108 A possível superabilidade que aqui se defende é da norma jurídica, e não do texto legal, conforme precisa orientação de Fernando Vasconcellos: "A esta altura, já se pode dizer que a derrotabilidade alude a normas jurídicas e não a textos inseridos no direito positivo. (...). No nível sintático da linguagem, onde residem as previsões textuais 'em-si-mesmas', destoadas de qualquer interpretação, não há margem para qualquer questionamento acerca da derrotabilidade. $\underline{\mathbf{O} \text { texto, }}$ por si mesmo e sem a intervenção do intérprete, não irá se 'derrotar.'”. VASCONCELLOS, Fernando Andreoni. $O$ conceito de derrotabilidade normativa. Dissertação para obtenção do grau de Mestre no Curso de Pós-Graduação da Universidade Federal do Paraná. Disponível em $<$ http://dspace.c3sl.ufpr.br/dspace/bitstream/handle/1884/18639/O\%20conceito\%20de\%20derrota bilidade $\% 20$ normativa $\% 20-\% 20$ Fernando\%20Andreoni\%20Vasconcellos.pdf?sequence=1>., $\quad$ p. 52 - destacou-se.
} 
segundo defende, poderiam ser enumeradas previamente à aplicação da norma ${ }^{109}$.

O sistema formulado por Dworkin, todavia, conforme veiculado em precisa crítica de Robert Alexy, é demasiadamente simples, na medida em que não admite a possibilidade, ainda que excepcional, de se introduzir uma cláusula de exceção em uma regra quando de sua aplicação para solucionar um determinado caso concreto. Em certas situações, de fato, tal medida se faz necessária, já que "nunca é possível ter certeza que, em um novo caso, não será necessário a introdução de uma nova cláusula de exceção."110.

Da mesma forma, após apresentar uma série de exemplos em que regras jurídicas foram, por razões práticas, legitimamente superadas pelo julgador, posiciona-se Humberto Ávila contrariamente ao modelo de aplicação das regras formulado por Dworkin, já que não se pode atribuir às normas jurídicas em geral e, em especial, às regras, um caráter absoluto:

\begin{abstract}
"Os casos acima enumerados, aos quais poderiam ser somados, indicam que a consequência estabelecida prima facie pela norma pode deixar de ser aplicada em face de razões substanciais consideradas pelo aplicador, mediante condizente fundamentação, como superiores àquelas que justificam a própria regra. Ou se examina a razão que fundamenta a própria regra (rule's purpose) para compreender, restringindo ou ampliando, o conteúdo de sentido da hipótese normativa, ou se recorre a outra razões, baseadas em outras normas, para justificar o descumprimento daquela regra (overruling). Essas consideracões bastam para demonstrar que não é adequado afirmar que as regras 'possuem' um modo absoluto 'tudo ou nada' de aplicacão. Também as normas que aparentam indicar um modo incondicional de aplicação podem ser objeto de superação por razões não imaginadas pelo legislador para os casos normais.'
\end{abstract}

É preciso que aqui se ressalte, contudo, que admitir que regras válidas em abstrato possam ser eventualmente superadas pelo intérprete,

\footnotetext{
109 "Of course a rule may have exceptions (...). However, an accurate statement of the rule take this exception into account, and any that did not would be incomplete. If the list of exceptions is very large, it would be too clumsy to repeat them each time the rule is cited; there is, however, no reason in theory why they could not all be added on, and the more that are, the more accurate is the statement of the rule.". DWORKIN, Ronald. Taking rights seriously., p. 24/25 destacou-se.

${ }^{110}$ ALEXY, Robert. Teoria dos Direitos Fundamentais., p. 104.

111 ÁVILA, Humberto. Teoria dos Princípios - da definição à aplicação dos princípios jurídicos., p. 51.
} 
não implica em dizer que, nesse aspecto, elas se confundam com os princípios. Não se abandona aqui a ideia de que a superação das regras, ao contrário dos princípios, deve ser tratada como uma medida de exceção em nosso sistema.

A singularidade das duas espécies normativas, nesse ponto, decorre do fato de que "os princípios possuem uma superabilidade imanente, enquanto as regras possuem uma superabilidade excepcional."112. Por esse motivo, como se verá adiante, é que Ávila afirma que, ao contrário do que muitos autores sustentam, descumprir uma regra é mais grave para nosso ordenamento jurídico do que descumprir um princípio ${ }^{113}$.

Visto isso, podem ser identificadas, ao menos no que interessa ao presente estudo, duas principais situações nas quais a incidência de uma norma válida não irá necessariamente garantir a sua aplicação no caso concreto. São elas a hipótese de imprevisão legislativa e o caso do conflito em concreto entre normas jurídicas perfeitamente válidas, as quais são a seguir analisadas.

Como se sabe, os enunciados normativos são planejados para regulamentar situações concretas, específicas, imaginadas de maneira prévia pelo legislador ao formular os termos do texto legal. Nos casos em que a norma incide, assim, considera-se que os elementos de fato tidos como essenciais para sua aplicação estejam presentes.

Sucede, todavia, que, muitas vezes, determinadas condições fáticas que se apresentam como fundamentais para aplicação da norma em uma determinada hipótese estão implícitas no texto do enunciado que lhe serve de base. Consequentemente, é sempre possível que, em certos casos, muito embora os termos contidos no enunciado se apliquem à hipótese do ponto de vista linguístico, os elementos de fato que se consideram essenciais para provocar sua incidência não estarão nela presentes ${ }^{114}$.

${ }^{112}$ BUSTAMANTE, Thomas da Rosa de. Argumentação contra legem: a teoria do discurso e a justificação jurídica nos casos mais difíceis., p. 220.

113 ÁVILA, Humberto. Teoria dos Princípios - da definição à aplicação dos princípios jurídicos., p. 112.

${ }^{114}$ BARCELLOS, Ana Paula de. Ponderação, racionalidade e atividade jurisdicional., p. 229. 
Isso se dá em razão da impossibilidade prática do legislador prever todas as situações que poderão ser enquadradas no texto legal, mas que, eventualmente, serão incompatíveis com a finalidade e os princípios subjacentes à norma dele extraída ${ }^{115}$. Nesse sentido, também, é a lição de Fernando Andreoni Vasconcellos, que, em trabalho dedicado ao tema, apresenta tal motivo como um dos fatos geradores da, por ele chamada, derrotabilidade das normas jurídicas:

"Ao legislar, uma autoridade legislativa não pode considerar mais do que os casos normais, mas sempre se pode pensar em casos reais ou imaginários atípicos que mereçam uma solução diferenciada. Por isso as obrigações e direitos consagrados em normas gerais devem ser entendidos como sujeitos a excecões implícitas.

Destarte, ante o acima exposto, como uma primeira situação em que se observa uma potencial superabilidade das normas jurídicas, é possível mencionar os casos de imprevisão legislativa, nos quais os valores que motivaram o legislador à criação do enunciado normativo, apesar da incidência a norma nele contida, não são realizados na prática.

A segunda hipótese aqui tratada em que se faz viável a eventual superação das normas jurídicas é, conforme já se mencionou, a de um incontornável conflito em concreto entre duas normas que, apesar da eventual tensão, são perfeitamente conciliáveis no plano abstrato e na grande maioria das hipóteses $^{117}$.

115 ÁVILA, Humberto. Teoria dos Princípios - da definição à aplicação dos princípios jurídicos., p. 128.

${ }^{116}$ VASCONCELLOS, Fernando Andreoni. O conceito de derrotabilidade normativa., p. 50.

${ }^{117}$ Interessante notar que a possibilidade de uma antinomia parcial entre duas normas jurídicas, i.e., observada apenas em determinados casos concretos, já era prevista na classificação de Tercio Sampaio Ferraz Junior, conforme a seguir: "Classificação quanto à extensão da contradição. Falase, conforme Ross (1970), em (1) antinomia total-total, quando uma das normas não pode ser aplicada em nenhuma circunstância, sem entrar em conflito com outra; (2) antinomia total-parcial, quando uma das normas não pode ser aplicada em nenhuma circunstância, sem entrar em conflito com outra, enquanto a outra tem um campo de aplicação que entra em conflito com a anterior apenas em parte; (3) antinomia parcial-parcial, quando as duas normas têm um campo de aplicação que em parte entra em conflito com o da outra, em parte não entra.". FERRAZ JUNIOR, Tercio Sampaio. Introdução ao estudo do direito: técnica, decisão, dominação. $4^{\mathrm{a}}$ ed. São Paulo: Atlas, 2003, p. 215 - destacou-se. 
Nesse ponto, relembre-se, mais uma vez, que não se está tratando aqui de uma incompatibilidade teórica entre normas, cuja consequência, como se sabe, é a invalidação de uma delas. Ademais, presume-se aqui que ambas as normas sejam plenamente constitucionais, já que, caso ausente este requisito em uma delas, o caso se resolveria de maneira simples e conhecida por todos: a declaração de inconstitucionalidade da norma em descompasso com a Constituição e a prevalência da outra.

Ao contrário, cuida-se aqui de casos singulares em nosso ordenamento jurídico em que se observa uma incontornável tensão entre regras absolutamente válidas e harmônicas entre si, cujo único resultado possível será a superação casuística de uma delas, ou, em outros termos, a criação de uma cláusula de exceção à aplicação de uma das regras em conflito $^{118}$.

Importante notar que, nesse caso, a superação de uma das regras jurídicas pelo julgador não será só possível como também necessária na prática. Com efeito, na hipótese de um inconciliável choque entre duas ou mais regras válidas e incidentes à hipótese, de modo que a sua coexistência não seja possível no caso concreto, evidente é que a superação de pelo menos uma delas se faz imprescindível para que se dê solução ao caso.

É possível dizer, portanto, diante da demonstração de que tanto regras quanto princípios são sujeitos a exceções casuísticas formuladas pelo julgador, que o Direito é um sistema de normas superáveis ${ }^{119}$. O próximo tópico do presente trabalho, dessa maneira, buscará enquadrar a superação da regra disposta no artigo 495 do CPC dentre uma das hipóteses acima mencionadas, de modo a demonstrar sua viabilidade prática.

\footnotetext{
118 BUSTAMANTE, Thomas da Rosa de. Argumentação contra legem: a teoria do discurso e a justificação jurídica nos casos mais difíceis., p. 228.

${ }^{119}$ Ibid., p. 171.
} 


\section{III.3. A potencial superabilidade da regra do artigo 495 do CPC}

Conforme acima demonstrado, não se pode justificar a desconstituição das decisões transitadas em julgado há mais de dois anos que violam norma de matriz constitucional pela ausência de condições do legislador de prever que a regra insculpida no artigo 495 do CPC tornaria decisões inconstitucionais imutáveis.

Nesse passo, a existência da coisa soberanamente julgada inconstitucional foi indubitavelmente prevista, bem como sua estabilidade desejada, pelo legislador ordinário quando da edição do referido dispositivo legal. Não se trata, então, de um caso de imprevisão legislativa.

A rescisão da coisa soberanamente julgada inconstitucional, dessa maneira, pode ser fundamentada pelo insustentável conflito, em um determinado caso concreto, entre a regra insculpida no artigo 495 do CPC e uma regra de origem constitucional. Nesse caso, não é exagero afirmar que a rescisão da coisa soberanamente julgada não será somente possível, como também provável, uma vez que a regra processual ora comentada é, como se sabe, de hierarquia inferior às regras constitucionais ${ }^{120}$.

Certamente, no caso da coisa soberanamente julgada, a tensão entre tais normas terá sua origem na ofensa pela decisão judicial tornada imutável pelo efeito do tempo a uma regra (ou ao núcleo de um princípio) de matriz constitucional, seja porque a decisão violou diretamente, por meio de seu conteúdo, uma regra constitucional, seja porque a decisão aplicou para a solução do caso uma norma que viole uma regra constitucional ${ }^{121}$.

Assim, diante de seu incontornável conflito em concreto com uma regra de hierarquia superior, será perfeitamente viável, e até mesmo provável, que a regra que impõe o limite temporal para a rescisão da coisa

\footnotetext{
${ }^{120} \mathrm{O}$ conflito normativo observado na hipótese em que a coisa soberanamente julgada ofende determinada regra constitucional, contudo, pode ser muito mais complexo, dependendo das circunstâncias do caso concreto, e não necessariamente implicará em sua rescisão. É o que se demonstrará no próximo Capítulo.

${ }^{121}$ São essas - relembre-se - as duas possibilidades que Paulo Otero aponta de violação por uma decisão judicial à Constituição Federal. OTERO, Paulo. Ensaio sobre o caso julgado inconstitucional., p. 65/75.
} 
julgada seja casuisticamente superada e, por consequência, autorize-se a desconstituição da res iudicata após o prazo de dois anos do trânsito em julgado da sentença judicial.

Ademais, é de se acrescentar que, em razão de a ação rescisória, como visto, ser o único instrumento processual apto a desconstituir a coisa julgada, o meio próprio de se rescindir uma decisão transitada em julgado há mais de dois anos será a propositura da chamada ação rescisória $e x$ tempore, entendida como aquela ajuizada após o esgotamento do limite temporal para seu manejo.

Como se afere de trecho da obra de Marcelo Cunha de Araújo abaixo transcrito, a solução aqui apresentada à coisa soberanamente julgada inconstitucional também foi prevista por tal processualista que, após concluir ser a rescisória o único meio de desconstituição das decisões transitadas em julgado, dispõe:

\footnotetext{
"Assim, não é o Supremo Tribunal Federal ou o Superior Tribunal de Justiça ou qualquer outro Tribunal o competente à desconstituição da coisa julgada. Na verdade, o caso deverá ser tratado como acão rescisória comum, com a única peculiaridade processual (na verdade, existem várias outras peculiaridades, porém materiais) de sua propositura após o prazo do art. 495 do CPC."
}

Nesse contexto, cumpre aqui mencionar um exemplo prático em que, apesar de sua indiscutível incidência, a regra extraída do artigo 495 do CPC deixou de ser aplicada, tendo em vista a colisão, in casu, com uma regra de ordem constitucional. Permitiu-se, assim, em uma ação rescisória, a citação de um litisconsorte passivo necessário mesmo depois de esgotado o prazo de dois anos da irrecorribilidade da sentença rescindenda.

$\mathrm{Na}$ hipótese que ora se apresenta, propôs-se ação rescisória, fundada no artigo 485, V, do CPC, contra decisão do Plenário do Tribunal de Justiça de Santa Catarina que, incidentalmente, havia declarado a inconstitucionalidade da incidência de contribuição previdenciária sobre os proventos de inativos, instituída pela Emenda Constitucional 41/2003.

${ }^{122}$ ARAÚJO, Marcelo Cunha de. Coisa Julgada Inconstitucional: Hipóteses de Flexibilização e Procedimentos para Impugnação., p. 202. 
Note-se, por essencial, que os dispositivos introduzidos pela referida Emenda, e que haviam sido considerados inconstitucionais pela E. Corte catarinense, instituíram uma norma com indiscutível natureza de regra, segundo a qual também os servidores inativos deveriam contribuir para o custeio da Previdência Social ${ }^{123}$.

Ademais, como pano de fundo, registre-se que, posteriormente à prolação da decisão rescindenda, o Supremo Tribunal Federal, ao julgar improcedentes as ADI's 3.105 e 3.128, declarou a constitucionalidade dos dispositivos introduzidos pela aludida emenda na Constituição Federal.

Assim, a certa altura do processo, percebeu-se que um dos autores da ação em que havia sido proferida a decisão rescindenda não havia sido citado, muito embora sua incontroversa condição de litisconsorte passivo necessário. Nesse momento, porém, já havia se esgotado o prazo bienal previsto no artigo 495 do CPC.

Diante de tal quadro, discutia-se no precedente em questão a possibilidade de citação, e consequente integração ao polo passivo da ação rescisória, de uma nova parte no processo mesmo após o fim do prazo de dois anos do trânsito em julgado da decisão impugnada.

Como resultado, sob o fundamento de que a inconstitucionalidade da decisão transitada em julgado não convalesceria em momento algum, entre outros, decidiu o Pleno do Tribunal de Justiça de Santa Catarina que o prazo bienal para a rescisão da coisa julgada deveria ser desconsiderado no caso concreto. Confira-se, assim, trecho do acórdão em que resta claro a adoção deste raciocínio:

"Inicialmente, porém, como questão lógico-necessária ao exame da matéria,
observo que a participação de Nauro Luiz Guimarães Collaço é realmente
necessária à validade da relação processual, incidindo o entendimento regra
quanto à imperatividade do litisconsórcio passivo. Impetrante no mandado de

\footnotetext{
${ }^{123}$ Conforme se extrai do artigo $4^{\circ}$ da $\mathrm{EC} \mathrm{n}^{\circ} 41 / 2003$, a qual modificou o artigo 40 da Constituição Federal: "Art. $4^{\circ}$ Os servidores inativos e os pensionistas da União, dos Estados, do Distrito Federal e dos Municípios, incluídas suas autarquias e fundações, em gozo de benefícios na data de publicação desta Emenda, bem como os alcançados pelo disposto no seu art. $3^{\circ}$, contribuirão para 0 custeio do regime de que trata 0 art. 40 da Constituicão Federal com percentual igual ao estabelecido para os servidores titulares de cargos efetivos." - destacou-se.
} 
segurança originário e beneficiário direto da decisão rescindenda, é clara sua pertinência subjetiva para figurar na extremidade passiva da lide, suportando os efeitos de virtuais rescisão e julgamento. Nesse caso, o litisconsórcio se instaura em caráter de imprescindibilidade, não se vendo o feito apto a julgamento enquanto ausente a citação do réu omitido.

Tenho, contudo, como possível sanar o vício na instauração da lide (art. 47, parágrafo único, CPC), ainda que decorrido lapso superior a um biênio entre a data do trânsito em julgado da sentença rescindenda e a data de prolação da decisão que determinou a citacão (art. 495, CPC). E assim o tenho porque a rescisória veicula, como causa de pedir, a superveniência da decisão do Excelso Pretório que, em controle concentrado de constitucionalidade, tido como de efeito vinculante e erga omnes, declarou a viabilidade de incidência de contribuicãa previdenciária sobre os proventos da inatividade (ADIs 3105 e 3128), negando o direito adquirido à isenção, comando inverso ao exarado na decisão rescindenda. Alega-se, portanto, a existência de sentenca acoimada de inconstitucionalidade oblíqua, porque nega vigência à incidência da Lei Maior.

Na pintura dessa causa petendi, eleita a ação rescisória como via de impugnação, o biênio decadencial se me afigura inaplicável, posição que passo a justificar sem que isso implique, ao revés do afirmado, incursão precipitada no juízo de mérito. (...).

Posto estas premissas, força é notar que a sentença inconstitucional, caso assim venha se a configurar em ulterior juízo de mérito, porque encerrando o vício maior do ordenamento jurídico, situa-se no plano das decisões nulas de pleno direito, nisso se distanciando da simples rescindibilidade, associada à só ilegalidade. O grau de violação à ordem jurídica é transcedente.

(...)

Penso, após reflexão, que a primeira das inclinações é a consentânea com a natureza do vício, permitindo a propositura da ação rescisória e, por extensão, a regularização do litisconsórcio passivo a qualquer tempo. É que, se a sentença inconstitucional, em tese, não convalesce, não há sentido em aplicar-lhe o prazo decadencial da acão rescisória, prazo esse destinado exclusivamente à formação da coisa soberanamente julgada, imunizada de toda e qualquer vício, porque se o vício não se imuniza a utilidade do prazo se esvazia. Não vejo espaço, portanto, a que se condicione o uso da ação rescisória ao prazo bienal, equiparando, em potencial, a inconstitucionalidade à ilegalidade.

Portanto, a partir do precedente ora comentado, é possível cogitar de situações em que a colisão entre a regra decorrente da interpretação do artigo 495 do CPC e uma regra protegida pela Constituição Federal, implique em uma situação de insustentável inconstitucionalidade, a qual justifique a criação de uma cláusula de exceção à sua aplicação.

Nesses casos, a solução para o conflito não deverá ser a inconstitucionalidade do aludido dispositivo legal, como visto, mas sim a casuística superação de seu sentido mínimo por meio de uma genuína

${ }^{124}$ TJ/SC, Tribunal Pleno, Agravo Regimental em Ação Rescisória nº 2006.002504-8, Rel. Des. Maria do Rocio Luz Santa Ritta, Santa Catarina, julgamento de 07.02.2007 - destacou-se. 
decisão contra legem, com todas as suas características típicas já apresentadas.

No entanto, será que se pode afirmar de forma absoluta que em todas as hipóteses em que se observa uma violação pela coisa soberanamente julgada à regra constitucional, a decisão deverá ser rescindida? É de se indagar, ainda, se também a ofensa pela decisão transitada em julgado há mais de dois anos a um princípio constitucional não poderia acarretar em sua reforma. E o conflito em concreto entre a regra do artigo 495 do CPC e outra regra infraconstitucional? Como deve ele ser resolvido?

Essas e outras situações concretas serão tratadas no próximo Capítulo, o qual, de forma a não exaurir o tema, traça alguns parâmetros objetivos a serem considerados pelo julgador quando diante de uma possível superação casuística do limite temporal para a rescisão da res iudicata. 


\section{Capítulo IV - A potencial superação da regra do artigo 495 do CPC em conflito com outras normas jurídicas - construção de parâmetros específicos para a rescisão da coisa soberanamente julgada}

Conforme visto no Capítulo anterior, a superação casuística da regra disposta no artigo 495 do CPC, nas hipóteses em que essa entre em um incontornável conflito com regras de matriz constitucional, é plenamente viável em nosso sistema jurídico, o que será novamente demonstrado aqui.

No entanto, resta ainda saber se em todos os casos em que a coisa soberanamente julgada vai de encontro à determinada regra constitucional deverá necessariamente a decisão judicial ser rescindida. Cumpre investigar, ainda, se também a violação por parte da decisão judicial a um princípio constitucional poderia acarretar em sua desconstituição. Por fim, é imprescindível que se analise de que forma o conflito em concreto entre a regra do artigo 495 do CPC e outra regra infraconstitucional deverá ser solucionada pelo julgador.

O exame das possíveis situações de colisão normativa, como já se disse, terá o condão de antecipar os casos em que a regra disposta no artigo 495 do CPC poderá, diante de um conflito em concreto com outra norma jurídica, ser superada, de modo a se rescindir a coisa soberanamente julgada $^{125}$.

Assim é que este último Capítulo, partindo do conflito em concreto entre as normas que dão suporte à intangibilidade da coisa soberanamente julgada (principalmente a regra disposta no artigo 495 do CPC) e outras normas de nosso sistema jurídico, se dedicará à importante tarefa de construção de parâmetros objetivos, os quais poderão orientar o julgador a

\footnotetext{
${ }^{125}$ Ressalte-se novamente, contudo, que, por óbvio, não se tem a mínima pretensão de se adiantar todos os casos possíveis de conflitos normativos causados pela inconstitucionalidade da coisa soberanamente julgada - até porque, como se sabe, as particularidades fáticas do caso concreto são, por definição, infinitas - mas apenas de se construir alguns parâmetros específicos que poderão orientar o julgador em sua decisão de admitir ou não uma ação rescisória ex tempore.
} 
decidir pela rescisão ou manutenção de uma decisão transitada em julgada há mais de dois anos.

Ao final, ver-se-á que cumpre, principalmente, ao Supremo Tribunal Federal, órgão que tem a competência máxima pela guarda da Constituição, dizer, por meio de sua jurisprudência, quais são as hipóteses nas quais o limite temporal não poderá ser superado para a reforma da decisão judicial transitada em julgado.

\section{IV.1. A ofensa pela decisão transitada em julgado há mais de dois anos a princípio constitucional}

Em primeira ordem, cabe aqui enfrentar a hipótese em que uma decisão transitada em julgada há mais de dois anos ofenda um determinado princípio constitucional. Nesse caso, será que a regra do artigo 495 do CPC poderia ser superada, de modo a permitir o ajuizamento de ação rescisória a qualquer tempo?

Para que se responda à pergunta acima formulada, cumpre, inicialmente, reproduzir aqui a interessante imagem que Ana Paula de Barcellos tem da estrutura dos princípios jurídicos, tendo em vista sua utilidade para a investigação do objeto do presente estudo.

Conforme ensina a autora, os princípios podem ter sua estrutura descrita como dois círculos concêntricos. No círculo interior, encontra-se seu núcleo, o qual, como se detalhará mais à frente, corresponde ao sentido mínimo da norma. Na parte externa do círculo (coroa circular), por sua vez, está a área de expansão do princípio, na qual o sentido e os efeitos que esse produzirá no mundo dos fatos são indeterminados ${ }^{126}$.

É neste último espaço, com efeito, que a deliberação democrática atuará. Aqui, os Poderes Legislativo e Executivo exercerão suas respectivas

\footnotetext{
${ }^{126}$ Há de se esclarecer, contudo, que tal constatação não implica em dizer que a área não nuclear dos princípios não pretenda produzir efeito algum. Isso porque, conforme ensina Barcellos, os princípios, em toda sua extensão, exercem importante função na interpretação dos enunciados normativos (eficácia interpretativa), na invalidação de atos e decisões contrários aos seus preceitos (eficácia negativa) e, quando seja o caso, vedativa do retrocesso. BARCELLOS, Ana Paula de. Ponderação, racionalidade e atividade jurisdicional., p. 191.
} 
competências legiferantes, formulando os sentidos que os princípios deverão assumir para além de suas áreas nucleares ${ }^{127}$.

Nesse ponto, imprescindível salientar que as regras infraconstitucionais têm um importante papel nesta definição, uma vez que, conforme já outrora demonstrado, são o produto de uma ponderação prévia realizada pelo legislador ordinário a partir do conflito entre os princípios colidentes in casu.

Os comandos ventilados nas regras jurídicas, seguindo essa linha de raciocínio, podem ser vistos como uma escolha democrática do sentido que o princípio constitucional deverá assumir em sua área não nuclear, assim como dos efeitos que deverá produzir caso observada a hipótese fática descrita na norma ${ }^{128}$.

Justamente por esse motivo, assim, é que se pode afirmar, como parâmetro geral dos conflitos normativos, que em caso de uma eventual tensão entre uma regra infraconstitucional e a área não nuclear de um princípio constitucional, a regra jurídica deverá prevalecer. Nesse caso, a restrição ao princípio não está conclusivamente proibida ou permitida, estando-se aqui diante da margem de livre apreciação do legislador ${ }^{129}$.

Por conseguinte, não será legítimo que o intérprete dê um sentido diverso para o princípio daquele estipulado na regra, sob pena de desconstrução de toda uma lógica que permeia nosso sistema legal. Aqui, o comando contido na regra deverá ser respeitado e o sentido do princípio, consequentemente, comprimido. Senão vejamos:

\footnotetext{
"Ao se afastar uma regra sob o fundamento de que ela se oporia a alguma conduta derivada da área não nuclear de um princípio, incorre-se em um conjunto de distorções. Em primeiro lugar, caso se trate de uma regra infraconstitucional, o intérprete estará conferindo à sua concepcão pessoal acerca do melhor
}

\footnotetext{
${ }^{127}$ Ibid., p. 179.

128 "Os princípios, para além de seu núcleo, estabelecem as fronteiras de um largo campo de atuação possível, dentro de cujos limites as opções políticas podem ser consideradas legítimas. As regras correspondem exatamente a decisões políticas específicas, de efeitos determinados, já tomadas no interior de tais fronteiras." Ibid., p. 192.

${ }^{129}$ BUSTAMANTE, Thomas da Rosa de. Conflitos normativos e decisões contra legem: uma nota sobre a superabilidade das regras jurídicas., p. 136/137.
} 
desenvolvimento do princípio maior importância do que à concepcão majoritária, apurada pelos órgãos legitimados para tanto.."130

Destarte, aplicando-se o parâmetro geral aqui enunciado ao campo de estudo do presente trabalho, chega-se à irretorquível conclusão de que a ofensa pela coisa soberanamente julgada à área não nuclear dos princípios jurídicos, na medida em que representa um choque em concreto entre a última e a regra disposta no artigo 495 do CPC, não é suficiente para ensejar a rescisão da decisão judicial estabilizada por período superior a dois anos.

$\mathrm{Na}$ hipótese ora tratada, por certo, o limite temporal para o ajuizamento da ação rescisória e, consequentemente, para a desconstituição da res iudicata, deverá ser respeitado pelo julgador.

Entretanto, sabe-se que as restrições criadas pelas regras infraconstitucionais aos princípios, apesar de plenamente admissíveis em nosso sistema, como já demonstrado ao longo do presente trabalho, não podem ultrapassar o denominado conteúdo essencial dos princípios fundamentais $^{131}$. Nesse sentido, confira-se o entendimento de Gilmar Ferreira Mendes:

"Da análise dos direitos individuais pode-se extrair a conclusão direta de que direitos, liberdades, poderes e garantias são passíveis de limitação ou restrição.

É preciso não perder de vista, porém, que tais restrições são limitadas. Cogita-se aqui dos chamados limites imanentes ou 'limites dos limites' (Schranken-Schranken), que balizam a ação do legislador quando restringe direitos individuais. Esses limites, que decorrem da própria Constituição, referem-se tanto à necessidade de proteção de um núcleo essencial do direito fundamental quanto à clareza, determinação, generalidade e proporcionalidade das restrições impostas.",132

\footnotetext{
${ }^{130}$ BARCELLOS, Ana Paula de. Ponderação, racionalidade e atividade jurisdicional., p. 190 grifou-se.

${ }^{131}$ A aplicação da teoria do núcleo essencial dos princípios constitucionais, conforme dita Gilmar Ferreira Mendes, deve ser admitida no Brasil, muito embora a ordem constitucional não tenha a contemplado expressamente: "Embora o texto constitucional brasileiro não tenha consagrado expressamente a idéia de um núcleo essencial, afigura-se inequívoco que tal princípio decorre do próprio modelo garantístico utilizado pelo constituinte. A não-admissão de um limite ao afazer legislativo tornaria inócua qualquer proteção fundamental." MENDES, Gilmar Ferreira et. al. Curso de direito constitucional. $2^{\mathrm{a}}$ ed. São Paulo: Saraiva, 2008, p. 319.

${ }^{132}$ Ibid., p. 314/315 - grifou-se.
} 
Retomando a imagem dos princípios jurídicos como dois círculos concêntricos, pode-se dizer que o núcleo desta estrutura representa o espaço no qual está o sentido mínimo da norma, que será ocupado pelas condutas elementares para a sua realização ${ }^{133}$.

Com efeito, é possível que se estabeleça certas ações ou omissões que são absolutamente indispensáveis para que um determinado princípio constitucional seja obedecido. E isso porque, certos efeitos estão contidos de forma inexorável nos termos dos enunciados normativos que dão origem ao princípio $^{134}$.

Importante notar, desse modo, que, quando enxergado a partir de sua área nuclear, os efeitos que o princípio pretende irradiar no mundo dos fatos passam a ser determinados, e não indeterminados como no caso de sua área externa, motivo pelo qual, conforme sustenta Ana Paula de Barcellos, o núcleo dos princípios tem natureza de regra:

"a despeito de todas as indeterminações, é possível afirmar, com freqüência, que certos efeitos estão contidos de forma inexorável na descrição do princípio, até por força de uma imposição lingüística, já que toda expressão haverá de ter um sentido mínimo. Esse conjunto de efeitos forma um núcleo essencial de sentido do princípio, com natureza de regra, uma vez que se trata agora de um conjunto de efeitos determinados.

Dessa maneira, a área nuclear dos princípios constitucionais, por veicularem comandos concretos e objetivos emanados do Poder Constituinte, estará sempre a salvo das deliberações majoritárias, de modo

\footnotetext{
${ }^{133}$ BARCELLOS, Ana Paula de. Ponderação, racionalidade e atividade jurisdicional., p. 180.

134 Alerte-se aqui que, não obstante seja quase intuitiva a constatação de sua existência, não é simples, muito menos pacífica na doutrina, a forma pela qual o núcleo dos princípios constitucionais deve ser identificado na prática. Nesse passo, conforme aponta Gomes Canotilho, no que se refere à salvaguarda do núcleo essencial dos princípios, "discutem-se, fundamentalmente dois problemas: (1) qual o objecto de protecção: o direito subjetivo individual ou a garantia objectiva? (2) qual o valor da protecção: o núcleo essencial é um valor absoluto ou depende de sua confrontação com outros direitos ou bens?". CANOTILHO, J. J. Gomes. Direito constitucional e teoria da Constituição., p. 458/459. Nesta ocasião, contudo, as diversas correntes existentes sobre o tema não serão enfrentadas, tendo em vista que, para as pretensões do presente estudo, basta que se ateste que os princípios constitucionais apresentam um núcleo essencial, cuja função é de restringir as restrições do legislador.

135 BARCELLOS, Ana Paula de. Ponderação, racionalidade e atividade jurisdicional., p. 178 grifou-se.
} 
que, em caso de colisão com uma regra infraconstitucional, deverá sempre prevalecer $^{136}$.

Tal tensão normativa, por certo, pode ser observada nos casos em que a área nuclear de um determinado princípio constitucional é infringida por uma decisão judicial transitada em julgado há mais de dois anos. Haverá aqui uma evidente contradição em concreto entre o núcleo do princípio violado, que demandará do Poder Judiciário um novo pronunciamento sobre a questão, e a regra infraconstitucional insculpida no artigo 495 do CPC, a qual, por sua vez, reclamará que a decisão judicial seja mantida tal como lançada.

A desconstituição da coisa soberanamente julgada, nessa excepcional hipótese, não será somente possível como também necessária na prática, haja vista que o legislador infraconstitucional, mesmo nos casos em que está expressamente autorizado a editar normas restritivas, sempre encontrará a área nuclear do princípio constitucional como um limite que não pode ultrapassar.

Em caso de violação pela decisão judicial ao núcleo de um princípio constitucional, assim, deverá ser criada uma cláusula de exceção à regra que limita a desconstituição da coisa julgada ao prazo temporal de dois anos. Será esse, a propósito, o típico caso em que se reconhecerá a inconstitucionalidade da incidência da norma do artigo 495 do CPC, apesar de sua plena validade no plano abstrato ${ }^{137}$.

\footnotetext{
${ }^{136}$ Não parece ser outro o entendimento de Thomas Bustamante: "Quando a aplicação de uma regra jurídica interferir excessivamente em princípios considerados especialmente importantes, implicando uma manifesta injustiça no caso concreto, será possível criar uma exceção à regra em tela.”. BUSTAMANTE, Thomas da Rosa de. Argumentação contra legem: a teoria do discurso e a justificação jurídica nos casos mais difíceis., p. 240.

${ }^{137}$ Sobre esse mesmo fenômeno já se pronunciou o Supremo Tribunal Federal no julgamento da ADI $n^{\circ}$ 223/DF, na qual se discutia a constitucionalidade de disposições contidas em diversas Medidas Provisórias que vedavam a concessão de medidas liminares em desfavor da Fazenda Pública. No caso, entendeu a Corte por bem declarar a constitucionalidade dos enunciados normativos, com a explícita ressalva, contudo, de que poderá o magistrado, "se entender abusiva essa restrição, se a entender inconstitucional, conceder a liminar, deixando de dar aplicação, no caso concreto, à medida provisória, na medida em que, em relacãa àquele caso, a julgue inconstitucional, porque abusiva.". STF, ADI 223 MC/DF, Rel. p/ acórdão Min. Sepúlveda Pertence, Brasília, julgamento de 05.04.1990 - destacou-se.
} 
Portanto, não há dúvidas que nas situações em que uma decisão transitada em julgado há mais de dois anos viole o núcleo essencial de um princípio constitucional dever-se-á admitir o ajuizamento intempestivo de uma ação rescisória para desconstitui-la.

\section{IV.2. A violação pela coisa soberanamente julgada à regra infraconstitucional}

De fato, é de se admitir que a manutenção da coisa soberanamente julgada cuja decisão viole uma determinada regra jurídica, tenha ela matriz constitucional ou não, implicará, necessariamente, em seu expresso descumprimento pelo Poder Judiciário.

Assim, na situação aqui tratada, observa-se um conflito em concreto entre a regra que impõe um limite temporal para a rescisão da coisa julgada e a regra infraconstitucional infringida pela decisão, na medida em que as duas normas, apesar de serem teoricamente aplicáveis ao caso, impõem comportamentos contraditórios. Nesse caso, qual delas deveria prevalecer no caso concreto?

Em primeira ordem, importante que aqui se esclareça que o descumprimento por parte das decisões às normas jurídicas em geral e, em particular, às regras, nas hipóteses em que o pronunciamento judicial está protegido pelo manto da coisa julgada, é expressamente admitido em nosso ordenamento jurídico.

De fato, a partir de uma interpretação do artigo 474 do Código Processual, o qual dispõe que "passada em julgado a sentença de mérito, reputar-se-ão deduzidas e repelidas todas as alegações e defesas", em conjunto com o artigo 495 do mesmo diploma, afere-se que a legislação infraconstitucional impede que a coisa soberanamente julgada seja rescindida em virtude de eventuais violações a normas jurídicas ${ }^{138}$.

\footnotetext{
${ }^{138}$ Nesse sentido, Fredie Didier Jr.: “A coisa julgada cria uma sólida armadura em torno da decisão, tornando irrelevantes quaisquer razões que se deduzam no intuito de revê-la. $\underline{\text { Nem mesmo }}$
} 
Com isso, constata-se que a exceção ao cumprimento das normas pelas decisões judiciais, em caso de decadência do direito de rescindi-las, já é expressamente prevista pelo legislador ordinário ${ }^{139}$, razão pela qual, para que o Judiciário mantenha seu pronunciamento anterior, não é preciso que a regra infraconstitucional transgredida por tal decisão seja excepcionada pelo julgador $^{140}$.

Por outro lado, para que seja cumprida a regra já violada, o que se fará, invariavelmente, pela desconstituição da coisa soberanamente julgada, imprescindível é, como visto, que o julgador introduza uma exceção não escrita à norma insculpida no artigo 495 do diploma processual. Tal medida, contudo, conforme já demonstrado, é extremamente excepcional em nosso sistema e deve ser evitada sempre que possível.

Portanto, a partir da observância, de um lado, da expressa permissão legislativa para que as regras jurídicas sejam infringidas por decisões transitadas em julgado e, de outro, da extrema resistência de nosso sistema em admitir exceções à regra do artigo 495 do CPC, a coisa soberanamente julgada não pode ser desconsiderada pela simples violação à norma de hierarquia infraconstitucional.

Por fim, a corroborar o que está aqui a se sustentar, relembre-se que um dos motivos da dificuldade em se defender a rescisão da coisa soberanamente julgada é a de que, com isso, poder-se-ia abrir uma perigosa brecha para que o fenômeno fosse observado com frequência em nossa prática jurídica.

questões de ordem pública podem ser argüidas.". DIDIER JR., Fredie et. al. Curso de Direito Processual Civil, volume 2., p. 427 - grifou-se.

${ }^{139} \mathrm{Na}$ hipótese ora comentada, interessante notar que, em verdade, embora haja uma evidente contradição entre regras, não se pode dizer que há uma antinomia jurídica propriamente dita, na medida em que a própria legislação excepciona o cumprimento da regra infraconstitucional violada. Nesse sentido, conforme dispõe Tercio Sampaio Junior, para que haja propriamente uma antinomia jurídica, necessário é que o intérprete esteja em uma situação insustentável, de modo que não exista "no ordenamento dado, nenhuma regra que lhe venha em auxílio para que o sujeito decida uma questão". JUNIOR, Tercio Sampaio. Introdução ao estudo do direito: técnica, decisão, dominação., p. 211.

${ }^{140} \mathrm{O}$ mesmo raciocínio, contudo, como será visto à frente, não poderá ser sustentado em caso de violação à regra constitucional, já que o legislador ordinário, por um critério de hierarquia normativa, não pode criar exceções aos comandos definitivos da Constituição. 
Com efeito, como se viu ao longo do primeiro Capítulo, a possibilidade de generalização das hipóteses de rescisão da coisa soberanamente julgada é um dos principais fundamentos utilizados pelos autores da escola tradicional para rejeita-la, bem como uma das maiores preocupações da maioria daqueles que defendem a possibilidade de sua "relativização".

Nesse contexto, sabe-se que há um infindável número de regras de hierarquia infraconstitucional em nosso ordenamento, decorrentes da interpretação dos inúmeros enunciados normativos federais, estaduais e municipais existentes no país, as quais, como é intuitivo, não raro são violadas por decisões judiciais transitadas em julgado.

Por conseguinte, permitir que a coisa soberanamente julgada seja desconstituída simplesmente por violar uma regra infraconstitucional implica em tornar, de certa forma, cotidiano o afastamento casuístico da norma disposta no artigo 495 do diploma processual.

Nesse caso, não há dúvidas que não só os princípios constitucionais da segurança das relações jurídicas e da imodificabilidade das decisões transitadas em julgado seriam atingidos em seu núcleo essencial, como também a própria estrutura do Estado Democrático de Direito restaria sobremaneira fragilizada:

\footnotetext{
"Com efeito, a ponderação corriqueira de regras fragilizaria a própria estrutura do Estado de direito; pouco valeriam as decisões do Poder Legislativo se cada aplicação de um enunciado normativo se transformasse em um novo processo legislativo, no qual o aplicador passasse a avaliar, novamente, todas as conveniências e interesses envolvidos na questão, bem como todos os princípios pertinentes." ${ }^{141}$
}

Portanto, ante o aqui exposto, é de se concluir que o afastamento casuístico do limite temporal para rescisão da res iudicata, em linha de princípio, não pode ser justificado pela mera violação à regra infraconstitucional.

${ }^{141}$ BARCELLOS, Ana Paula de. Ponderação, racionalidade e atividade jurisdicional. p.188. 


\section{IV.3. A hipótese da coisa soberanamente julgada violadora de regra constitucional}

$\mathrm{O}$ mero descumprimento pela coisa soberanamente julgada à regra infraconstitucional, como se viu acima, não pode ensejar a sua rescisão, tendo em vista que: (i) esse é um fenômeno relativamente cotidiano em nossa prática legal, de tal forma que permitir que sua ocorrência tenha a prerrogativa de desconstituir a coisa soberanamente julgada comprometeria sobremaneira a segurança jurídica, bem como que; (ii) o legislador infraconstitucional expressamente excepcionou o cumprimento das normas jurídicas pelas decisões transitadas em julgado por período superior a dois anos.

Nesse passo, embora sejam tais argumentos suficientes para justificar a manutenção de uma decisão transitada em julgado que transgrida norma infraconstitucional, os mesmos não podem ser aplicados para o caso de conflito em concreto entre a regra processual que limita em dois anos a possibilidade de rescisão da coisa julgada e uma determinada regra constitucional, como se passa a expor.

Em primeira ordem, apesar de nossa Constituição Federal ser conhecidamente prolixa, parece certo que o número de regras que pode dela ser extraído é infinitamente menor do que a quantidade daquelas que decorrem da interpretação dos enunciados infraconstitucionais.

Tal conclusão, nesse particular, decorre não só da óbvia constatação de que existe um infindável número de enunciados infraconstitucionais em nosso sistema e, em contrapartida, apenas um único diploma constitucional, mas também do fato de que nossa Carta Magna tem uma clara feição principiológica, utilizando-se, com maior abundância do que outros documentos legislativos, das cláusulas gerais e dos princípios jurídicos ${ }^{142}$.

\footnotetext{
${ }^{142}$ Veja-se, sobre o tema, a lição de Luís Roberto Barroso: "O texto constitucional se utiliza, com abundância maior do que outros documentos legislativos, de cláusulas gerais, que são categorias normativas pelas quais se transfere para o intérprete, com especial intensidade, parte do papel de
} 
Como consequência, sabe-se que raros são os casos em que se pode realmente afirmar que uma decisão judicial infringiu uma regra constitucional ou, em outros termos, um comando objetivo da Lei Fundamental.

Ao contrário do que ocorre na hipótese anteriormente tratada, admitir que a transgressão de uma regra constitucional possa, de forma isolada, fundamentar a rescisão da coisa soberanamente julgada, não tem o condão de banalizar a superação da regra disposta no artigo 495 do CPC, o que somente poderá ocorrer em casos pontuais.

No que se refere à inaplicabilidade à hipótese sob análise do segundo fundamento utilizado para justificar o parâmetro anterior, ademais, é de se admitir, como já mencionado no presente trabalho, que era do objetivo do legislador infraconstitucional, ao prever um limite temporal para o manejo da ação rescisória, tornar intangível a coisa soberanamente julgada que violasse não só normas infraconstitucionais, como também normas da Constituição Federal.

No entanto, conforme demonstrado alhures, por uma simples questão de hierarquia normativa, a regra do artigo 495 do diploma processual não pode introduzir exceções aos comandos definitivos da Constituição, como o faz com a legislação infraconstitucional. Nessa hipótese, não sendo possível a coexistência das duas normas ${ }^{143}$, o conflito em concreto entre a regra processual e a regra violada, oriunda da Carta Magna, deverá ser resolvido pela prevalência da regra constitucional.

criação do Direito, à luz do problema a ser resolvido. De fato, caberá a ele, tendo em conta os elementos do caso concreto, fazer valorações específicas e densificar conceitos indeterminados como interesse público e justa indenização, de um lado, ou princípios como a dignidade da pessoa humana e igualdade, de outro." BARROSO, Luís Roberto. Curso de direito constitucional contemporâneo: os conceitos fundamentais e a construção do novo modelo., p. 198. Em sentido contrário à classificação da Constituição Federal de 1988 como principiológica, confira-se a crítica de Humberto Ávila. ÁVILA, Humberto. "NEOCONSTITUCIONALISMO": ENTRE A "CIÊNCIA DO DIREITO" E O "DIREITO DA CIÊNCIA". Revista Eletrônica de Direito do Estado (REDE), Salvador, Instituto Brasileiro de Direito Público, no 17, janeiro/fevereiro/março, 2009. Disponível em <http://www.direitodoestado.com/revista/REDE-17-JANEIRO-2009HUMBERTO\%20AVILA.pdf>. Acesso em 24.10.2012.

${ }^{143}$ Nesse ponto, relembre-se que o embate em concreto entre regras jurídicas só pode ser resolvido pela formulação de exceções a uma delas. 
Assim, de forma idêntica ao que se observou nas hipóteses de ofensa ao núcleo essencial dos princípios constitucionais (que, não por acaso, tem natureza de regra), a casuística superação da norma disposta no artigo 495 do $\mathrm{CPC}$, em caso de violação pela decisão judicial à determinada regra constitucional, tem como fundamento a inconstitucionalidade de sua incidência no caso concreto.

Por conseguinte, a solução a ser tomada pelo julgador aqui, assim como lá, deverá ser, em princípio, a admissão da ação rescisória após o prazo decadencial de dois anos do trânsito em julgado, com a subsequente desconstituição da coisa soberanamente julgada e uma nova manifestação do Poder Judiciário sobre a questão.

Entretanto, uma análise mais acurada da hipótese ora comentada permite revelar que nem sempre a solução para o caso de ofensa pela decisão judicial à regra constitucional será a simples rescisão da coisa soberanamente julgada. Isso porque, diversas circunstâncias factuais poderão elevar em muito a complexidade do conflito normativo a ser resolvido pelo julgador.

Com efeito, imagine-se, por exemplo, uma situação na qual a decisão judicial tenha transitado em julgado há mais de trinta anos, período no qual tenha produzido seus efeitos sem que nenhum interessado tenha requerido sua reforma. Ou então a hipótese em que os jurisdicionados tenham depositado um alto grau de confiança na manutenção da decisão, adotando medidas extremamente custosas com base em suas determinações ${ }^{144}$.

Será que, nesses excepcionais casos, a solução pela desconstituição da coisa julgada não acabaria por atingir em cheio o núcleo essencial dos

\footnotetext{
144 Sobre o tema, elenca Anderson Schreiber os seguintes indícios factuais que indicam a ocorrência de uma legítima confiança por parte do indivíduo: “(i) a efetivação de gastos e despesas motivadas pelo factum proprium, (ii) a divulgação pública das expectativas depositadas, (iii) a adoção de medidas ou a abstenção de atos com base no comportamento inicial, (iv) o grau elevado de sua repercussão exterior, (v) a ausência de qualquer sugestão de uma futura mudança de comportamento, e assim por diante.”. SCHREIBER, Anderson. A proibição do comportamento contraditório - Tutela da confiança e venire contra factum proprium. $2^{\mathbf{a}}$ edição. Rio de Janeiro: Renovar, 2007, p. 141/142. Ressalte-se que embora em seu texto trate o autor da legítima confiança como pressuposto do comportamento contraditório, sua lista pode ser de extrema utilidade para se aferir, no caso concreto, o grau de violação por parte da decisão judicial ao princípio da segurança jurídica nas hipóteses em que rescinde a coisa soberanamente julgada.
} 
princípios constitucionais da segurança jurídica e da intangibilidade do caso julgado?

Em sendo a resposta a tal indagação positiva, certo é que não será possível ao intérprete se utilizar do parâmetro segundo o qual as regras, em caso de conflito, têm preferência em relação aos princípios, já que, nessa hipótese, as duas normas em tensão terão a mesma estrutura de regra. Igualmente, não poderá se valer do critério da hierarquia, uma vez que ambas as normas terão matriz na Constituição.

Nessa toada, é de se salientar que a averiguação acerca da existência de uma eventual contradição em concreto entre uma regra constitucional e a área nuclear de um princípio constitucional remonta, em certa medida, a antiga discussão travada sobre a existência de "normas constitucionais inconstitucionais" ${ }^{\prime 145}$.

Tal complexa investigação, contudo, foge ao escopo do presente trabalho, sendo suficiente, para os fins a que se destina, atestar aqui que a solução para a hipótese da coisa soberanamente julgada violadora de regra constitucional não é tão simples como parece, sendo certo que, por vezes, não será recomendável que o Poder Judiciário desconstitua a res iudicata, ainda que a decisão que lhe baseie viole uma regra constitucional.

De qualquer modo, pode-se dizer que, como regra geral, tal fenômeno exigirá do julgador que aceite a ação rescisória ex tempore e, por consequência, rescinda intempestivamente a res iudicata, pronunciando-se

${ }^{145}$ O julgamento da ADI 815/DF representa o leading case do Supremo Tribunal Federal sobre o tema, no qual se concluiu pela inexistência de normas constitucionais inconstitucionais em abstrato, tendo em vista, resumidamente, a impossibilidade de o Poder Judiciário (Poder Constituído), exercer seu controle sobre o Poder Constituinte Originário, assim como a inexistência de hierarquia entre as normas da Constituição. STF, ADI 815/DF, Rel. Min. Moreira Alves, Brasília, julgamento de 28.03.1996. Contudo, mais recentemente, parece ter a Corte reconhecido a possibilidade de uma incontornável contradição em concreto entre regras constitucionais. Na IF 2.915/SP, resumidamente, decidiu a Corte não declarar a intervenção federal no Estado de São Paulo, muito embora a reiterada recusa do ente federativo, dada sua complicada situação financeira à época, em pagar precatórios judiciais relativos a créditos alimentícios. Como justificativa, argumentou o Supremo que as regras que determinam investimentos mínimos em saúde e educação (198, § 2 $2^{\circ}$ e 212 da CF), as quais seriam descumpridas na prática caso as referidas dívidas fossem imediatamente pagas (o que, naturalmente, seria uma consequência da intervenção), deveriam prevalecer em relação àquelas que dispõem acerca do pagamento dos precatórios alimentícios (arts. 100, $\S 5^{\circ}$, da Constituição e 78 do ADCT). STF, Tribunal Pleno, IF 2.915/SP, Rel. Min. Marco Aurélio, Brasília, julgamento de 03.02.2003. 
novamente sobre a questão de modo a obedecer o comando veiculado na regra violada.

\section{IV.4. A importância do respeito aos precedentes na universalização das hipóteses de rescisão da coisa soberanamente julgada}

Formulados acima alguns parâmetros objetivos que poderão ser utilizados para orientar a decisão pela desconstituição da coisa soberanamente julgada, passa-se aqui a brevemente analisar o papel da jurisprudência e do respeito aos precedentes na consolidação das hipóteses nas quais se deverá excepcionar o cumprimento à regra disposta no artigo 495 do CPC.

Haja vista a alta complexidade que envolve o tema, tem a doutrina a importante função de forjar, mesmo antes que o conflito normativo ocorra no caso concreto, as diretrizes que deverão nortear o intérprete na decisão pela desconstituição da coisa soberanamente julgada, o que se dará, conforme se buscou fazer no presente Capítulo, a partir da discussão de casos hipotéticos ou passados.

Com isso, nas hipóteses em que a tensão, antes amplamente discutida pela doutrina, entre as normas que determinam a intangibilidade do caso julgado e aquelas que eventualmente apontam em sentido contrário se reproduza em um caso real submetido ao crivo do Poder Judiciário, o magistrado terá à sua disposição modelos de solução pré-prontos, os quais poderão facilitar imensamente o seu trabalho ${ }^{146}$.

Pode-se afirmar, contudo, que é do Poder Judiciário e, em especial, do Supremo Tribunal Federal - a quem, conforme indica o artigo 102, caput $^{147}$, compete, precipuamente, a guarda do texto constitucional - o

\footnotetext{
146 As constatações acerca das vantagens na construção prévia de standards para a hipótese de conflitos normativos, bem como a ideia em si, são de Ana Paula de Barcellos. BARCELLOS, Ana Paula de. Ponderação, racionalidade e atividade jurisdicional., p. 146/151.

147 "Art. 102. Compete ao Supremo Tribunal Federal, precipuamente, a guarda da Constituição, cabendo-lhe: (...)."
} 
papel principal na consolidação das hipóteses em que a regra do artigo 495 do CPC poderá ser superada.

Isso porque, não obstante o grande valor de formulações acadêmicas no desenvolvimento das hipóteses em que o limite temporal para a desconstituição da res iudicata merecerá ser desconsiderado, não deverão ter elas, para o julgador, a mesma carga persuasiva (e, muitas vezes, vinculativa) dos precedentes judiciais.

Tal constatação decorre, por certo, da enorme importância do respeito pelo Judiciário aos entendimentos consolidadas em decisões anteriores por ele proferidas. Com isso, conforme esclarece Patrícia Perrone Campos Mello, garante-se que princípios fundamentais em nossa sociedade sejam realizados, como o da segurança jurídica, da isonomia entre os jurisdicionados, da eficiência do Judiciário e da legitimidade institucional das Cortes ${ }^{148}$.

Nessa linha, é possível que se diga que o apego aos precedentes deve ser ainda mais intenso nos casos em que o Poder Judiciário desconstitui a coisa soberanamente julgada, na medida em que, nesse caso, é imprescindível ao julgador que supere a regra legislativa disposta no artigo 495 do CPC a partir da criação de uma regra de exceção ${ }^{149}$.

\footnotetext{
148 Conforme esclarece a autora, "a obrigação de seguir as decisões anteriores garante a previsibilidade do direito, sua estabilidade e continuidade, tendo em vista que a solução as aplicada a uma causa determinará o desfecho das demandas assemelhadas. Preserva, igualmente, o tratamento isonômico entre os jurisdicionados, impondo aos magistrados que, ao apreciarem um litígio, reflitam não apenas quanto à resposta a ser dada à hipótese sob exame, mas, igualmente, a todos os demais conflitos que se enquadrem em uma mesma categoria de similitude; exige, portanto a busca de um fundamento objetivo, que seja dotado de pretensão de universalidade. (...). Além disso, o respeito aos julgados já proferidos incrementa a eficiência do sistema: provoca uma economia de tempo e de recursos, na medida em que torna desnecessárias novas considerações acerca daquelas matérias que já restaram pacificadas; diminui o risco de erro judicial; evita a produção de decisões conflitantes; e torna mais claro o direito, desestimulando demandas aventureiras e promovendo uma redução dos litígios. Tal estado de coisas preserva a legitimidade e a credibilidade das cortes aos olhos dos jurisdicionados, constituindo um importante fator de sua preservação institucional.”. MELLO, Patrícia Perrone Campos. Precedentes - O desenvolvimento judicial do direito no constitucionalismo contemporâneo. Rio de Janeiro: Renovar, 2008, p. 69/71.

${ }^{149}$ Veja, nesse sentido, o esclarecimento de Thomas Bustamante: "A efetiva superação de uma norma jurídica válida será tanto mais difícil quanto maior for o componente descritivocomportamental presente na sua moldura normativa. No entanto, ainda que estejamos diante da regra mais específica existente em um determinado tempo e lugar (chamemos aqui de R), sempre será possível surgir uma situação na qual a sua aplicação cause um rompimento no equilíbrio dos princípios que lhe servem de fundamento. Caso esse desequilíbrio cause uma restricão desproporcional e irracional num desses princípios, é possível que existam razões para a
} 
Por esse motivo, para que se confira o mínimo de legitimidade à norma emanada da decisão - a qual, repita-se, excepcionará o comando objetivo de uma regra legislativa - imprescindível é que a solução alcançada naquele específico caso concreto seja lançada em termos universais, repetindo-se nos casos futuros em que as circunstâncias fáticas determinantes para a criação da norma forem semelhantes.

Somente assim, certificando-se que a norma criada pelo julgador no caso concreto valha para todos, é que a decisão que desconstitui a coisa soberanamente julgada não poderá ser considerada um mero e pontual desrespeito do julgador ao ordenamento jurídico, mas sim uma consequência natural da evolução de nosso sistema jurídico:

\footnotetext{
"Toda decisão judicial, para estar justificada, tem de ser redigida em termos universais. Ela tem de apresentar as suas conclusões como emanando de uma regra que pode ser generalizada e deve ser repetida em todos os casos semelhantes, sob pena de séria violação aos princípios gerais da imparcialidade e da justiça formal. A norma especial que se estabelece para justificar a superabilidade é uma regra que se repete por forca da vinculacão ao precedente judicial. (...).

Uma decisão contra legem deixa de ser um caso de 'aplicação do direito' para se transformar em uma usurpação das prerrogativas da autoridade que a prolata se falta uma pretensão de juridicidade para a norma excecional que é formulada (em termos universais) para excepcionar a regra legislativa em um caso concreto." ${ }^{150}$
}

Desse modo, à guisa de conclusão, pode-se afirmar que a construção pelos Tribunais Superiores de standards, aliada a sua observância pelos demais órgãos do Judiciário por meio do respeito ao precedentes judiciais, permitirá que as normas judiciais criadas para excepcionar a regra disposta no artigo 495 do CPC sejam aplicadas indiscriminadamente a todos os jurisdicionados.

criação de uma nova regra ( $\mathbf{R}^{\prime}$ ), que valha como exceção para $\mathbf{R}$.”. BUSTAMANTE, Thomas da Rosa de. Argumentação contra legem: a teoria do discurso e a justificação jurídica nos casos mais difíceis., p. 234/235 - destacou-se.

${ }^{150}$ BUSTAMANTE, Thomas da Rosa de. Conflitos normativos e decisões contra legem: uma nota sobre a superabilidade das regras jurídicas., p. 140 - grifou-se. 


\section{Síntese conclusiva}

De modo a se resumir as principais ideias que permearam o presente trabalho, é possível que se formule as seguintes proposições, as quais, na medida do possível, serão apresentadas na ordem que os temas foram tratados ao longo texto:

1. A dificuldade em se admitir que a denominada coisa julgada inconstitucional possa ser desconstituída somente ocorre a partir do esgotamento do prazo decadencial disposto no artigo 495 do CPC. Antes disso, a decisão transitada em julgado que ofenda qualquer norma da Constituição pode ser perfeitamente rescindida por meio da ação rescisória fundada na violação à literal disposição de lei (art. 485, V, do CPC).

2. Conforme sustenta a doutrina tradicional sobre o tema, findo o prazo para o ajuizamento da ação rescisória, a coisa julgada não poderia, em nenhum caso, ser rescindida pelo Judiciário. Tal entendimento, porém, não pode ser acatado, pois assume que a regra que impõe um limite temporal para a rescisão das decisões transitada em julgado teria caráter absoluto, qualidade que nenhuma norma jurídica pode se valer.

3. Quanto à doutrina relativista, embora parta ela da correta premissa de que uma regra infraconstitucional possa ser eventualmente "relativizada", grande parte de seus autores incorre em exageros, tratando a modificação de uma decisão transitada em julgado há mais de dois anos como regra, e não como uma medida excepcional em nosso sistema.

4. Para a desconstituição da coisa soberanamente julgada, assim, necessário é que o Poder Judiciário profira uma decisão contra legem, haja vista que deverá superar, casuisticamente, a regra jurídica que, de forma mais evidente, pode ser extraída do artigo 495 do CPC.

5. A constatação acima aduzida decorre, inicialmente, do fato de que a ação rescisória é o único instrumento processual cabível para se rescindir a coisa julgada, sendo, por isso, obrigatória a incidência da norma que impõe um limite temporal para sua propositura. 
6. Ademais, sabe-se que o texto do artigo 495 do CPC deixa ao julgador um limitadíssimo espaço para interpretações, de modo que não é viável extrair do aludido enunciado normas alternativas que, porventura, autorizassem a rescisão da res iudicata após o esgotamento do prazo de dois anos do trânsito da sentença. Nesse caso, o sentido mínimo do dispositivo legal é, invariavelmente, transgredido.

7. Por fim, não há dúvidas acerca da constitucionalidade, assim como da grande importância para a realização do princípio da segurança jurídica, da regra que impõe um limite temporal para a rescisão da coisa julgada, razão pela qual o afastamento casuístico de sua aplicação não pode decorrer de sua invalidade em abstrato.

8. Por tais motivos, conclui-se que a rescisão da coisa soberanamente julgada depende, invariavelmente, de uma decisão judicial que, de forma casuística, supere uma regra jurídica perfeitamente válida em abstrato. Assim, para que se analise sua viabilidade, imperioso é que, previamente, verifique-se a possibilidade de proferimento pelo Judiciário de decisões contra legem.

9. Pois bem. De início, sabe-se que a fiel obediência pelo Judiciário às regras tem a importante função de afastar a incerteza jurídica, evitar eventuais arbitrariedades do julgador, além de se apresentar como um fator de igualdade entre os indivíduos.

10. No que se refere à regra que limita em dois anos o direito de se desconstituir a coisa julgada, sua superação casuística encontra um resistência ainda maior em nosso sistema, tendo em vista, aqui, o inevitável comprometimento da segurança jurídica, bem como o fato de que o afastamento de sua aplicação sob o argumento da inconstitucionalidade de sua incidência prejudicará, necessariamente, a finalidade que se encontra escondida por detrás da norma.

11. No entanto, embora excepcional, a criação de exceções às regras jurídicas em geral e, em específico, à regra que estipula um limite temporal 
para a rescisão das decisões transitadas em julgado, não pode ser totalmente descartada.

12. Isso porque, como se viu, o Direito pode ser considerado um sistema de normas derrotáveis, no qual a principal diferença entre as normas que o compõe é a facilidade com a qual princípios e regras podem ser superados.

13. Com efeito, enquanto a superabilidade dos princípios é imanente, tendo em vista sua relativa indefinição de sentido, a possibilidade de seu cumprimento gradual, bem como sua interação conflituosa com as demais normas que integram o sistema, a derrotabilidade das regras é excepcional, pois elas decorrem de uma ponderação de princípios já realizada pelo legislador que, somente em casos verdadeiramente extraordinários, pode ser refeita pelo julgador no caso concreto.

14. Não obstante rara, a superação casuística das regras jurídicas é plenamente possível e, assim, pode ser justificada; (i) pela incompatibilidade do resultado da aplicação da norma com os valores que o legislador tinha a intenção de realizar e/ou; (ii) por uma incontornável tensão em concreto entre regras que, apesar de sua eventual incompatibilidade, são absolutamente válidas e harmônicas no plano abstrato.

15. A desconstituição da coisa soberanamente julgada, nessa linha, embora não decorra de uma imprevisão legislativa, uma vez que sua eventual existência foi indubitavelmente prevista pelo legislador ordinário, pode ser fundamentada pelo insustentável conflito, em um determinado caso concreto, entre a regra insculpida no artigo 495 do CPC e uma regra de origem constitucional.

16. Nesse caso, a superação casuística do limite temporal para ajuizamento da ação rescisória não será somente possível, como também provável, haja vista que tal regra processual é de hierarquia inferior às regras constitucionais. 
17. Visto a viabilidade, nos casos de violação a regras constitucionais, de se rescindir a res iudicata mesmo depois de esgotado o prazo de dois anos do trânsito em julgado, analisa-se, por fim, se o conflito em concreto da regra que impõe um limite temporal para desconstituição da coisa julgada com outras normas jurídicas também poderia acarretar nesse resultado.

18. Inicialmente, a violação por uma decisão judicial transitada em julgado há mais de dois anos à área não nuclear de um princípio constitucional não pode autorizar sua rescisão, tendo em vista que, como parâmetro geral, as regras, ainda que infraconstitucionais, tem preferência em relação aos princípios em caso de conflito. Nesse caso, a regra disposta no artigo 495 do CPC impede que a decisão seja modificada.

19. No entanto, nos casos em que a decisão que serve de base à coisa soberanamente julgada ofende o núcleo essencial de um princípio constitucional - o qual, em razão de sua estrutura, tem natureza de regra deve ser ela desconstituída. Isso porque, as restrições impostas pelo legislador infraconstitucional aos princípios constitucionais não podem ir além de seu núcleo de sentido.

20. Da mesma forma, como visto, o descumprimento ao comando de uma regra constitucional, por um critério de hierarquia normativa, é motivo hábil para ensejar a introdução de uma exceção casuística à norma disposta no artigo 495 do CPC.

21. Todavia, tal solução não será tão simples nos casos em que a rescisão da coisa soberanamente julgada possa ensejar o descumprimento ao núcleo dos princípios constitucionais da segurança jurídica e da intangibilidade do caso julgado. Nessas hipóteses, é de se concluir que, em linha de princípio, não será recomendável que o Judiciário desconstitua a res iudicata, ainda que a decisão que lhe baseie viole, no caso concreto, uma regra constitucional. 
22. Por fim, viu-se ser necessário à legitimidade das decisões que desconstituem a coisa soberanamente julgada que as hipóteses de superação da regra disposta no artigo 495 do CPC sejam universalizadas.

23. Para tanto, os Tribunais Superiores, por meio de sua jurisprudência, têm o importante papel de construir critérios objetivos para orientar o julgador quando diante do ajuizamento de uma ação rescisória $e x$ tempore, que deverão ser, em regra, seguidos pelos demais órgãos do Poder Judiciário por força do respeito aos precedentes judiciais. 


\section{REFERÊNCIAS BIBLIOGRÁFICAS}

AGRA JÚNIOR, Walter de. Flexibilização da Coisa Julgada Inconstitucional. Disponível em $<$ http://www.unicap.br/tede/tde_arquivos/4/TDE-2008-05-

17T094458Z-159/Publico/walter_dissert.pdf>

ALEXY, Robert. Teoria dos Direitos Fundamentais. Tradução de Virgílio Afonso da Silva. $2^{\text {a }}$ ed. São Paulo: Malheiros, 2012.

ALVIM, Arruda et al. Comentários ao Código de Processo Civil. Rio de Janeiro: GZ Editora, 2012.

ARAÚJO, Marcelo Cunha de. Coisa Julgada Inconstitucional: Hipóteses de Flexibilização e Procedimentos para Impugnação. Editora Lumen Juris: 2007.

ARMELIN, Donaldo. Flexibilização da coisa julgada. In: NASCIMENTO, Carlos Valder do; DELGADO, José Augusto (Org.). Coisa julgada inconstitucional. $2^{\mathrm{a}}$ ed. Belo Horizonte: Fórum, 2008, p. 201/238.

ÁVILA, Humberto. "NEOCONSTITUCIONALISMO": ENTRE A "CIÊNCIA DO DIREITO" E O "DIREITO DA CIÊNCIA". Revista Eletrônica de Direito do Estado (REDE), Salvador, Instituto Brasileiro de Direito Público, no 17, janeiro/fevereiro/março, 2009. Disponível em <http://www.direitodoestado.com/revista/REDE-17JANEIRO-2009-HUMBERTO\%20AVILA.pdf>. Acesso em 24.10.2012.

Teoria dos Princípios - da definição à aplicação dos princípios jurídicos. 13a ed. São Paulo: Malheiros, 2012.

BARCELLOS, Ana Paula de. Ponderação, racionalidade e atividade jurisdicional. Rio de Janeiro: Renovar, 2005. 
BARROSO, Luís Roberto. $O$ controle de constitucionalidade no direito brasileiro: exposição sistemática da doutrina e análise crítica da jurisprudência. $3^{\mathrm{a}}$ ed. São Paulo: Saraiva, 2008.

Curso de direito constitucional contemporâneo: os conceitos fundamentais e a construção do novo modelo. São Paulo: Saraiva, 2009.

Interpretação e aplicação da Constituição. $6^{\mathrm{a}}$ edição. São Paulo: Saraiva, 2008.

BUENO, Cassio Scarpinella. Curso sistematizado de direito processual civil: procedimento comum: ordinário e sumário, 2: tomo I. $2^{\text {a }}$ ed. São Paulo, Saraiva, 2009.

BUSTAMANTE, Thomas da Rosa de. Argumentação contra legem: a teoria do discurso e a justificação jurídica nos casos mais difíceis. Rio de Janeiro: Renovar, 2005.

. Conflitos normativos e decisões contra legem: uma nota sobre a superabilidade das regras jurídicas. In: FELLET, André Luiz Fernandes; DE PAULA, Daniel Giotti; NOVELINO, Marcelo (Org.). As novas faces do ativismo judicial. Salvador: Editora Jus PODIVM, 2011.

CÂMARA, Alexandre Freitas. Lições de direito processual, volume II. $16^{\mathrm{a}}$ ed. Rio de Janeiro: Lumen Juris, 2011.

- Relativização da coisa julgada material. Disponível em http://www.unipli.com.br/direito/PASTAS_DOS_PROFESSORES/L aura_/Leonardo/relativizacao_coisajulgada.pdf $>$. Acesso em 16.06.2012.

CANOTILHO, J. J. Gomes. Direito constitucional e teoria da Constituição. $7^{\mathrm{a}}$ Edição. Coimbra: Almedina, 2000.

CRAMER, Ronaldo. Ação Rescisória por Violação da Norma Jurídica. Salvador: Editora JusPODIVM, 2012. 
COUTURE, Eduardo J. Fundamentos do Direito Processual Civil. Tradução de Benedicto Giaccobini. Campinas: RED Livros, 1999.

DANTAS, Ivo. Coisa julgada inconstitucional: declaração judicial de inexistência. In: NASCIMENTO, Carlos Valder do; DELGADO, José Augusto (Org.). Coisa julgada inconstitucional. $2^{\mathrm{a}}$ ed. Belo Horizonte: Fórum, 2008, p. 238/286.

DANTAS, Ivo. Constituição \& Processo. Curitiba: Juruá, 2003.

DINAMARCO, Cândido Rangel. Relativizar a coisa julgada. Revista da Procuradoria do Estado de São Paulo. São Paulo, no 55/56, janeiro/dezembro de 2001.

DINAMARCO, Maria Conceição Alves. Ação Rescisória. São Paulo: Atlas, 2004.

DIDIER JR., Fredie et. al. Curso de Direito Processual Civil, volume 2. $5^{\mathrm{a}}$ ed. Salvador: Editora JusPODIVM, 2010.

DIDIER JR., Fredie; CUNHA, Leonardo José Carneiro da. Curso de Direito Processual Civil, volume 3. $8^{\mathrm{a}}$ ed. Salvador: Editora JusPODIVM, 2010.

DIDIER JR., Fredie et. al. Curso de Direito Processual Civil, volume 5. $2^{\mathrm{a}}$ ed. Salvador: Editora JusPODIVM.

DWORKIN, Ronald. Taking rights seriously. Cambridge: Harvard University Press, 1978.

FERRAZ JUNIOR, Tercio Sampaio. Introdução ao estudo do direito: técnica, decisão, dominação. $4^{\mathrm{a}}$ ed. São Paulo: Atlas, 2003.

MARINONI, Luiz Guilherme. O princípio da segurança jurídica dos atos jurisdicionais (a questão da coisa julgada material). Revista Jurídica. São Paulo, n. 317, p. 16, 16.03.2002.

MARINONI, Luiz Guilherme; ARENHART, Sergio Cruz. Processo de conhecimento, v.2. 9a ed. São Paulo: Editora dos Tribunais, 2011. 
MELLO, Patrícia Perrone Campos. Precedentes - O desenvolvimento judicial do direito no constitucionalismo contemporâneo. Rio de Janeiro: Renovar, 2008.

MENDES, Gilmar Ferreira et. al. Curso de direito constitucional. $2^{\mathrm{a}}$ ed. São Paulo: Saraiva, 2008.

MIRANDA, Pontes de. Tratado da ação rescisória das sentenças e de outras decisões. $5^{\text {a }}$ ed. Rio de Janeiro: Forense, 1976.

MOREIRA, José Carlos Barbosa. Comentários ao Código de Processo Civil, Lei no 5.869, de 11 de janeiro de 1973, vol. V: arts. 476 a 565. $14^{\mathrm{a}}$ ed. Rio de Janeiro: Forense, 2008.

NERY JUNIOR, Nelson. Teoria geral dos recursos. $6^{a}$ ed. São Paulo: Editora Revista dos Tribunais, 2004.

OTERO, Paulo. Ensaio sobre o caso julgado inconstitucional. Lisboa: Editora Lex, 1993.

RIZZARDO, Arnaldo. Limitações ao trânsito em julgado e desconstituição da sentença. Rio de Janeiro: Forense, 2009.

SCHREIBER, Anderson. A proibição do comportamento contraditório Tutela da confiança e venire contra factum proprium. $2^{\mathrm{a}}$ edição. Rio de Janeiro: Renovar, 2007.

SILVA, José Afonso da. Curso de Direito Constitucional Positivo. $32^{\mathrm{a}}$ ed. São Paulo: Malheiros, 2009.

SIQUEIRA, Pedro Eduardo Pinheiro Antunes de. A coisa julgada inconstitucional. Rio de Janeiro: Renovar, 2006.

SOARES, Carlos Henrique. Coisa julgada constitucional. Coimbra: Almedina, 2009.

TAVARES BORBA, Gustavo. Embargos Desconstitutivos - Estudo sobre sua Constitucionalidade. In Revista da Procuradoria Geral do Estado do Rio de Janeiro. Rio de Janeiro, n 54, 2001, p. 79/87. 
THEODORO JR., Humberto; FARIA, Juliana Cordeiro de. A coisa Julgada Inconstitucional e os Instrumentos Processuais para seu Controle. In Revista da AGU. Brasília, no 09, abr./2001. Disponível em $<$ http://www.agu.gov.br/sistemas/site/TemplateTexto.aspx?idConteu do $=104461 \&$ id_site $=1115 \&$ ordenacao $=1>$. Acesso em 12.08.2012. . Reflexões sobre o princípio da intangibilidade da coisa julgada e sua relativização. In: NASCIMENTO, Carlos Valder do; DELGADO, José Augusto (Org.). Coisa julgada inconstitucional. $2^{\mathrm{a}}$ ed. Belo Horizonte: Fórum, 2008, p. 161/199.

VASCONCELLOS, Fernando Andreoni. O conceito de derrotabilidade normativa. Dissertação para obtenção do grau de Mestre no Curso de Pós-Graduação da Universidade Federal do Paraná. Disponível em $<$ http://dspace.c3sl.ufpr.br/dspace/bitstream/handle/1884/18639/O\% 20 conceito $\% 20$ de $\% 20$ derrotabilidade $\% 20$ normativa $\% 20$ $\% 20$ Fernando\%20Andreoni\%20Vasconcellos.pdf?sequence $=1>$. Acesso em 20.10.2012.

WAMBIER, Teresa Arruda Alvim; MEDINA, José Miguel Garcia. $O$ Dogma da Coisa Julgada: hipóteses de relativização. São Paulo: Revista dos Tribunais, 2003.

WAMBIER, Teresa Arruda Alvim. Recurso especial, recurso extraordinário e ação rescisória. $2^{\mathrm{a}}$ ed. São Paulo: Revista dos Tribunais, 2008. 